Tér és Társadalom 6. 1992-3-4: 89-162

\title{
A KÖZÉP-JÓZSEFVÁROS ÉSZAKI TERÜLETÉRE KÉSZÜLÓ RÉSZLETES RENDEZÉSI TERV PROGRAMJA
}

(Detailed plan and program of the Northern part of Central-Josephstadt in Budapest)

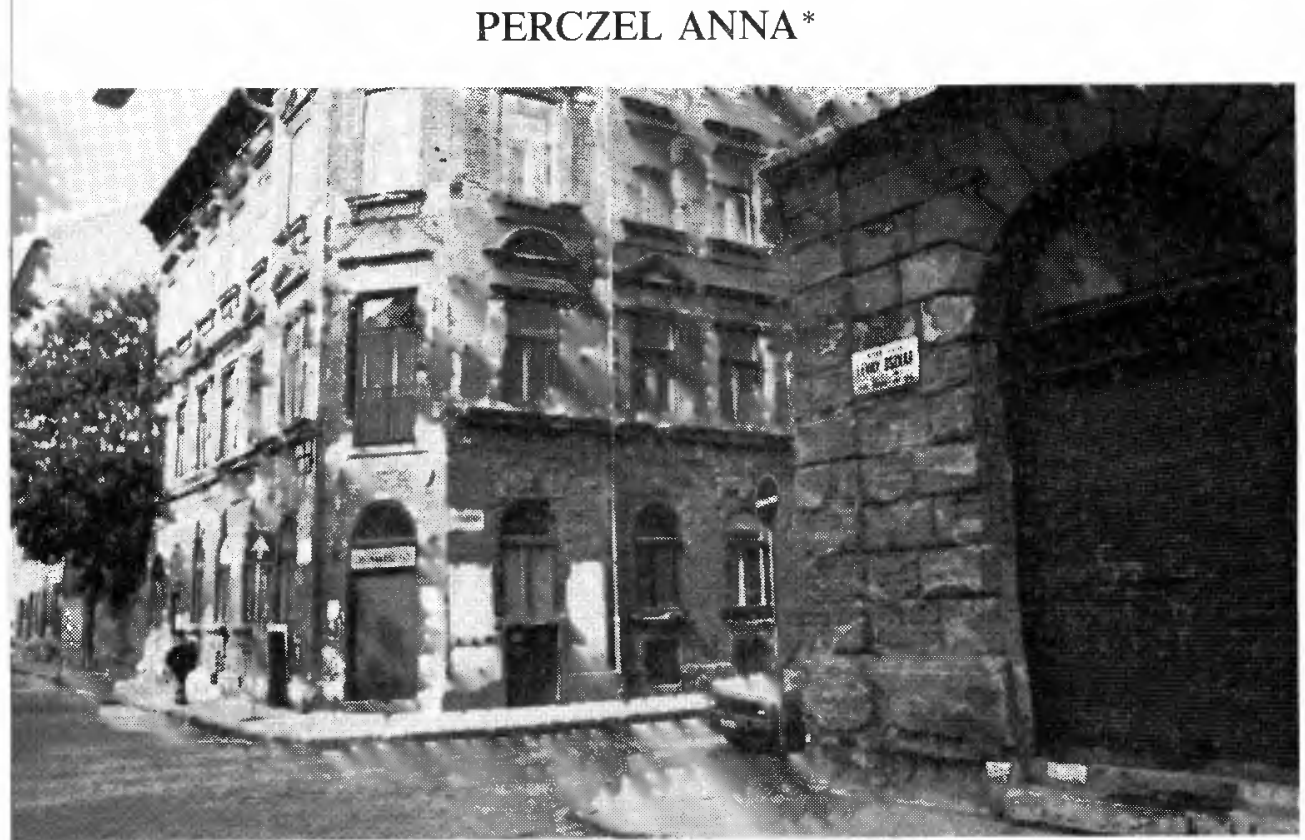

A Közép-Józsefváros északi területének részletes rendezési terve a Józsefvárosi Önkormányzat megbízásából készül a VÁTI Műemléki és Építészeti Tervezô Irodáján.

A terv a József körút-Rákóczi út-Fiumei út-Baross utca által határolt, rendkívüli módon leértékelốdött, hajdan népszerû városrésszel foglalkozik.

A tervet készítố munkacsoport tagjai:

Vezetố építész: Perczel Anna

Munkatársak: Rab Ildikó, Varga Nóra

Fôvárosi szerkezeti összefüggések: Miklóssy Endre

Mû̉emléki tanácsadó: Korompay Katalin

Fotók: Lábass Endre

Társadalmi összefüggések: Dr. Berey Katalin, Ladányi János

*A városszerkezeti-közlekedési problémák és összefüggések címũ fejezet szerzóje Miklóssy Endre.

A fotókat Lábass Endre készítette 
Perczel Anna : A Közép-Józsefváros északi területére készülö részletes rendezési terv programja

(Detailed plan and program of the Northern part of Central-Josephstadt in Budapest)

Tér és Társadalom 6. évf. 1992/3-4. 89-162. p.

90 Perczel Anna

TÉT $1992 \cdot 3-4$

Közgazdasági-gazdálkodási összefüggések: Vasi Ildikó, Varga Ö. Béla

Környezetvédelem és zöldterület: Gyarmati Edit

Közlekedés: Heckenast Judit

Közmú: Turányi Gáborné

Irodaigazgató: Dr. Máté Zsolt

A jelen cikk az 1992-ben elkészült program azon részeit tartalmazza, melyek a nagyobb, általánosabb összefüggéseket, javaslatokat érintik.

\section{Bevezetó-elöszó}

A fớváros Nagykörúton kívül elhelyezkedố városrészeinek sorában a legnehezebb helyzettel és problémákkal kell szembenéznie a Józsefváros e középső részének, ahol oly jellegzetes terekhez is kapcsolódó - ,világok" találhatók, mint a Rákóczi tér, a Mátyás tér, a Teleki tér vagy a Köztársaság tér és környéke.

Olyan városrészrốl van szó, ahol a határoló fơútvonalak, a József körút, Rákóczi út, Baross utca, Népszínház utca, egységes és nagyvárosias beépítése mögött különleges hangulatú kisvárosias, olykor falusias jellegú utcák, tömbök, beépítések találhatók, ma már építészetileg szinte egyedül képviselve a fơváros e XIX. századi kisvárosiasabb korszakát. A városrészben e különleges, egyedülálló adottság mellett ugyanakkor a legfeltưnốbb állapot a romlás, a pusztulás, a leépülés és az ezzel szorosan összetartozó, egyre gyorsabban terjedố szlömösödés és társadalmi erózió. Évtizedek óta ide gyúlik, itt talál menedéket a leromlott lakóépületek e helyen tömegesen rendelkezésre álló komfortnélküli lakásaiban a vidéki munkanélküliség elốl menekülốk (szakképzetlenek, szegények, cigányok) igen nagy része, de itt található a fôvváros egyetlen, területileg is meghatározható prostituált negyede is.

Mindezzel összefügggésben - mint minden hasonló, leértékelôdổ helyzetư városrészben tapasztalható, folyamatos és rendkívül erốs, a jobb helyzetư, tanultabb polgári családok elköltözése, és az itt maradók elöregedése.

A különbözổ beépítési módok, a középületek és lakóépületek sokfélesége és minôségi változatossága ugyanakkor a józsefvárosi élet hajdani sokszínúségére, tagoltságára utal, és arra az idổre emlékeztet, amikor a Józsefvárosnak ezt a részét még mozik, kávéházak, kertvendéglók, iparegyletek és munkáskörök sokasága jellemezte.

A magyar, német és szlovák ajkú iparosok mellett itt élt a pesti zsidóság jelentôs, bár szegényebb része, és mellettük itt élt a fôvárosi cigányság egy része is, elsósorban a cigányság felsố rétegeihez tartozó muzsikus cigány családok. De írók, mũvészek is nagyszámban laktak abban az idốben a Józsefvárosnak ezen a részén. Kávéházait, kertvendéglôit és kocsmáit pedig a fôváros más részeiból is felkeresték.

Ezekben az idốkben az itt élố józsefvárosi polgárság, az itt élố és itt mứködô iparosok, vállalkozók, szervezett munkások egyaránt jelen voltak és fontos szerepet játszottak a kerület és a fốváros életében.

Ma azonban mindennek szinte nyoma sincs, vagy csak töredékében van jelen, és egyre nyilvánvalóbb az a tény, hogy a fốvárosnak ezen a területén nagyvárosi gettó van kialakulóban. 
Perczel Anna : A Közép-Józsefváros északi területére készülő részletes rendezési terv programja

(Detailed plan and program of the Northern part of Central-Josephstadt in Budapest)

Tér és Társadalom 6. évf. 1992/3-4. 89-162. p.

Mindez látszólag a Józsefvárosnak csak ezen részére korlátozódik, de látni lehet, látni kell, hogy magából a városból is egyre nagyobb területet hódít meg, és e folyamatnak igen erổs kihatása van és lesz a fôvárosra, annak életére, társadalmi békéjére, abban az esetben, ha továbbra sem történik semmi, ami oldaná ezt a rendkívüli helyzetet.

Hogyan történhetett, mi az oka annak, hogy a fốvárosnak ezen a jelentốs, Belvároshoz oly közelesõ̉ részén ilyen mértékü a leépülés, és mi az, ami megfordíthatná ezt a rendkivül kedvezốtlen, egyirányú folyamatot?

E program javaslatainak megfogalmazásakor a fenti kérdések megválaszolásával próbálkoztunk, bár nyilvánvaló, hogy e rendezési terv a válaszok megadására önmagában nem elegendô. Arra alkalmas, hogy segítségével a városrészben rejlố, a kimozdulást elôsegítô városépítészeti lehetốségeket végig lehessen gondolni.

A városrész történetét, kialakulását, fejlődését mai helyzetét is megismerve, megốrzendố értékeinek és megoldandó problémáinak feltárása, majd e program kialakítása szociológusokkal és közgazdászokkal együtt, közös munkaként történt. Azért van különleges jelentôsége ennek a közös munkának, mert úgy véljük, hogy ennek a valamikor izgalmasan sokrétú, de sohasem könnyũ helyzetũ városrésznek a megújulása - a leépülés ilyen stádiumában csak az egész területre kisugárzó rehabilitációs átalakulással oldódhatna meg. Itt a csak egy-egy épületre, telekre, kisebb területekre szóló változás nem segít. Ezért e rendezési terv programjának kialakítása során már szinte minden javaslatunk a rehabilitáció elôkészítésére is vonatkozik.

A rehabilitációt a városrészre jellemzổ adottságokra és értékekre építve, léptékéhez igazodva képzeltük el, a városrész lakóinak részvételével - többségük ittmaradására számítva -, de egyben építészeti és környezeti, társadalmi és gazdasági megújulásra is gondolva.

Mindez így együtt egyáltalán nem könnyư, de ehhez az ideálhoz kellene közeledni, hiszen ez a rehabilitáció lényege.

Ugyanakkor tudjuk, hogy egyetlen rendezési terv sem lehet tökéletes. Ezért különösen fontosnak tartanánk, ha ezek a javaslatok egy állandóan megújuló, tehát nem merev, hanem élő programmá-tervvé, illetve együttgondolkodássá alakulnának, melyhez ez a munka lehetne a kiindulópont.

Az együttgondolkodásban az önkormányzat képviselới mellett egyaránt számítunk a városrész lakóira: bérlớkre és tulajdonosokra, az itt mûködố intézményekre, iskolákra, egyházakra, vállalatokra, iparosokra, üzlettulajdonosokra, társadalmi- és kisebbségi szervezetekre, de külsổ vállalkozókra, bankokra is. Ezen kívül, a városrész fổvárosban elfoglalt központi fekvése, összefonódó kapcsolatrendszere, de a városrész leépülésének mértéke miatt is, szoros együttgondolkodásra és együttmúködésre van szükség a fốvárossal is.

Mindez nemcsak azért fontos, hogy elốrelátó, megfontolt és érzékeny terv születhessen, hanem a rehabilitáció megvalósíthatóságának esélye miatt is elengedhetetlen. A leépülés ilyen fokán ugyanis nem tartjuk elképzelhetổnek a csupán vállalkozói alapon történố rehabilitációt! Szükség van az együttgondolkodásban résztvevớk aktív részvételére, de elsôsorban a jól elốkészített és megszervezett programok alapján a fổváros, és esetleg a kormány által is támogatott hosszúlejáratú hitelek felvételére. De szükség van különleges, a rehabilitációt érintô, ezen belül új lakások építését és a régiek rendbehozását egyformán inspiráló, jogi-, pénzügyi- és adóügyi szabályozásra is, mert enélkül a felvázolt helyzet oldása nem lehetséges. 
Perczel Anna : A Közép-Józsefváros északi területére készülő részletes rendezési terv programja

(Detailed plan and program of the Northern part of Central-Josephstadt in Budapest)

Tér és Társadalom 6. évf. 1992/3-4. 89-162. p.

Ez az éló és változó terv egy követhetổ értékrendet is feltételez.

$\mathrm{Az}$ az értékrend, melyhez javaslataink kialakítása során igazodtunk, részben a régi európai városok hagyományaira épül, melyekre - mint a hajdani Józsefvárosra is - jellemzô a sokféle városi funkció: a lakás-munka-közlekedés-mũvelơdés-szórakozás-pihenés egymás melletti lehetốsége, a kulturális és szociális sokféleség: mely egyúttal a legkülönbözôbb helyzetứ, életkorú és foglalkozású emberek együttélését is jelenti/jelentette.

Másrészt a mai kor új kihívásainak is meg kell felelnie, hiszen választ kell találni ezen a városrészen belül is, a környezetet súlyosan terhelô, a közösségi élet színtereit felemésztố, a gépkocsi által diktált új rend és a természetes emberi környezet között feszülő ellentmondásra, a , gettó" negatív jelenségeinek csillapítása mellett az etnikai szigetek védelmére, a történelmi és kulturális folyamatosságot jelentô és biztosító épületek és társadalmi szisztémák megổrzése mellett a mai kort képviselố építészet és az új vállalkozások megvalósítására is.

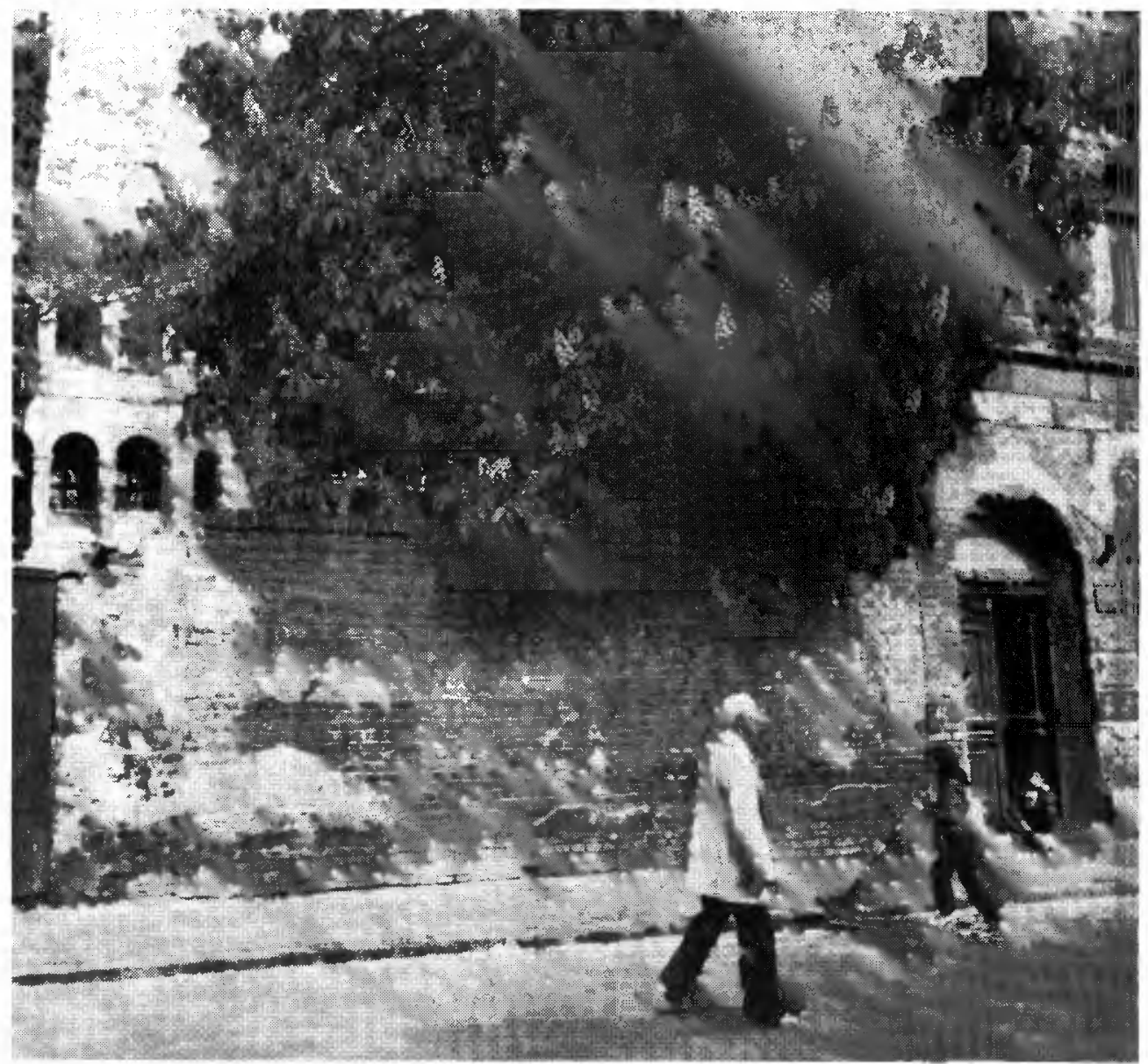


Perczel Anna : A Közép-Józsefváros északi területére készülő részletes rendezési terv programja

(Detailed plan and program of the Northern part of Central-Josephstadt in Budapest) Tér és Társadalom 6. évf. 1992/3-4. 89-162. p.
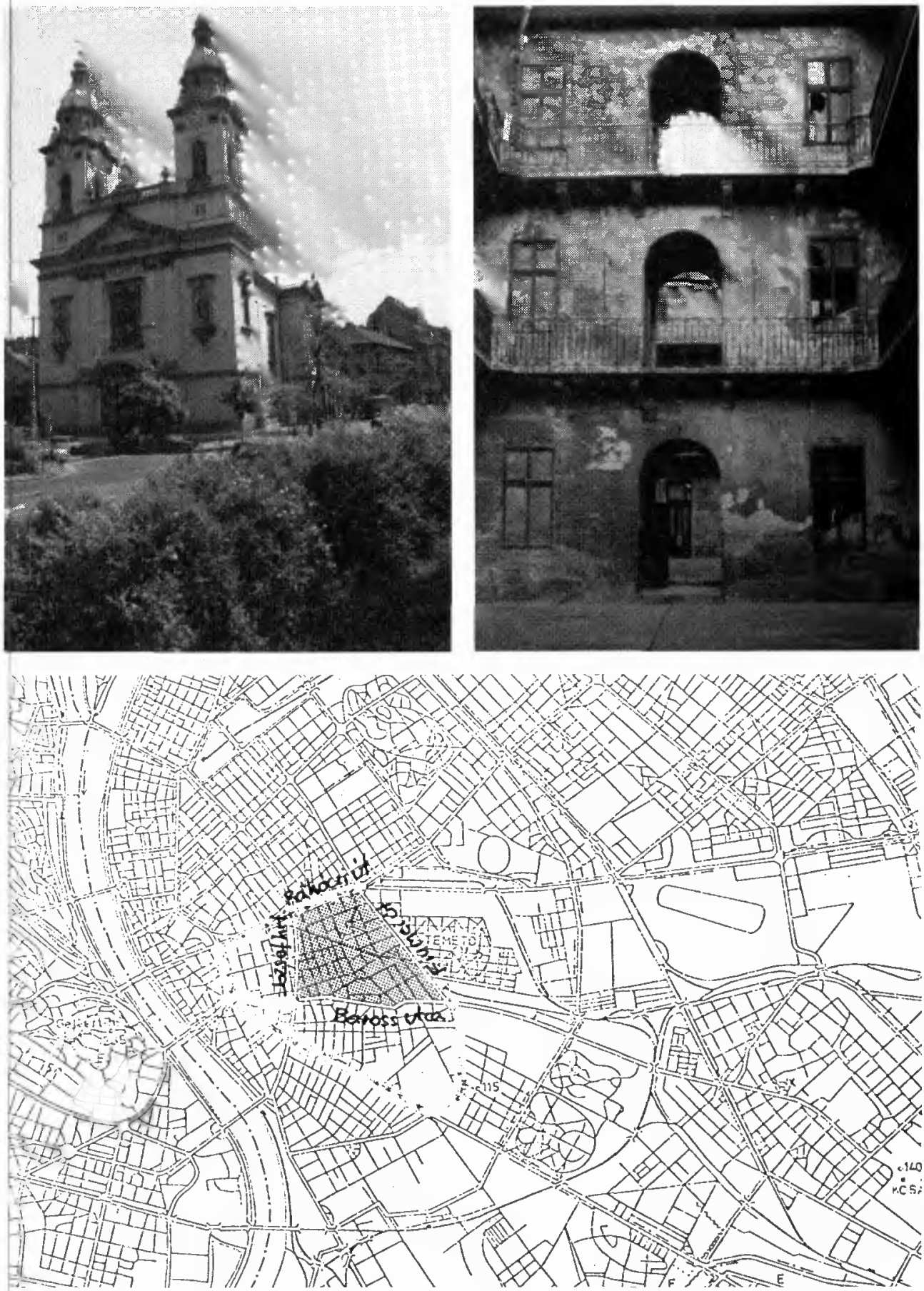

A városrész elhelyezkedése a fövárosban 
Perczel Anna : A Közép-Józsefváros északi területére készülő részletes rendezési terv programja

(Detailed plan and program of the Northern part of Central-Josephstadt in Budapest)

Tér és Társadalom 6. évf. 1992/3-4. 89-162. p.

94 Perczel Anna

TÉT $1992 \cdot 3-4$
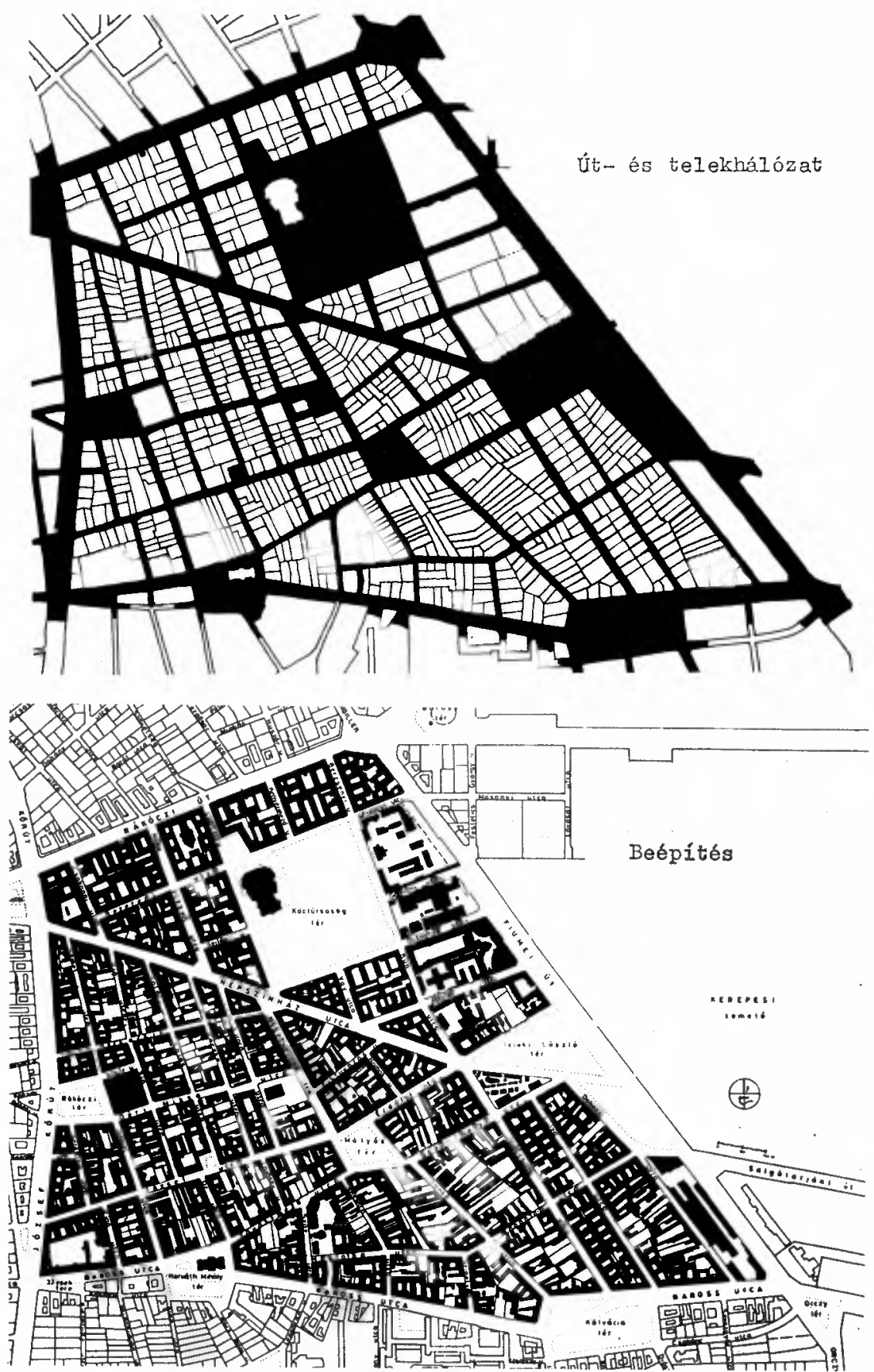

$A$ városrész szerkezete és beépitése 
Perczel Anna : A Közép-Józsefváros északi területére készülő részletes rendezési terv programja (Detailed plan and program of the Northern part of Central-Josephstadt in Budapest) Tér és Társadalom 6. évf. 1992/3-4. 89-162. p.
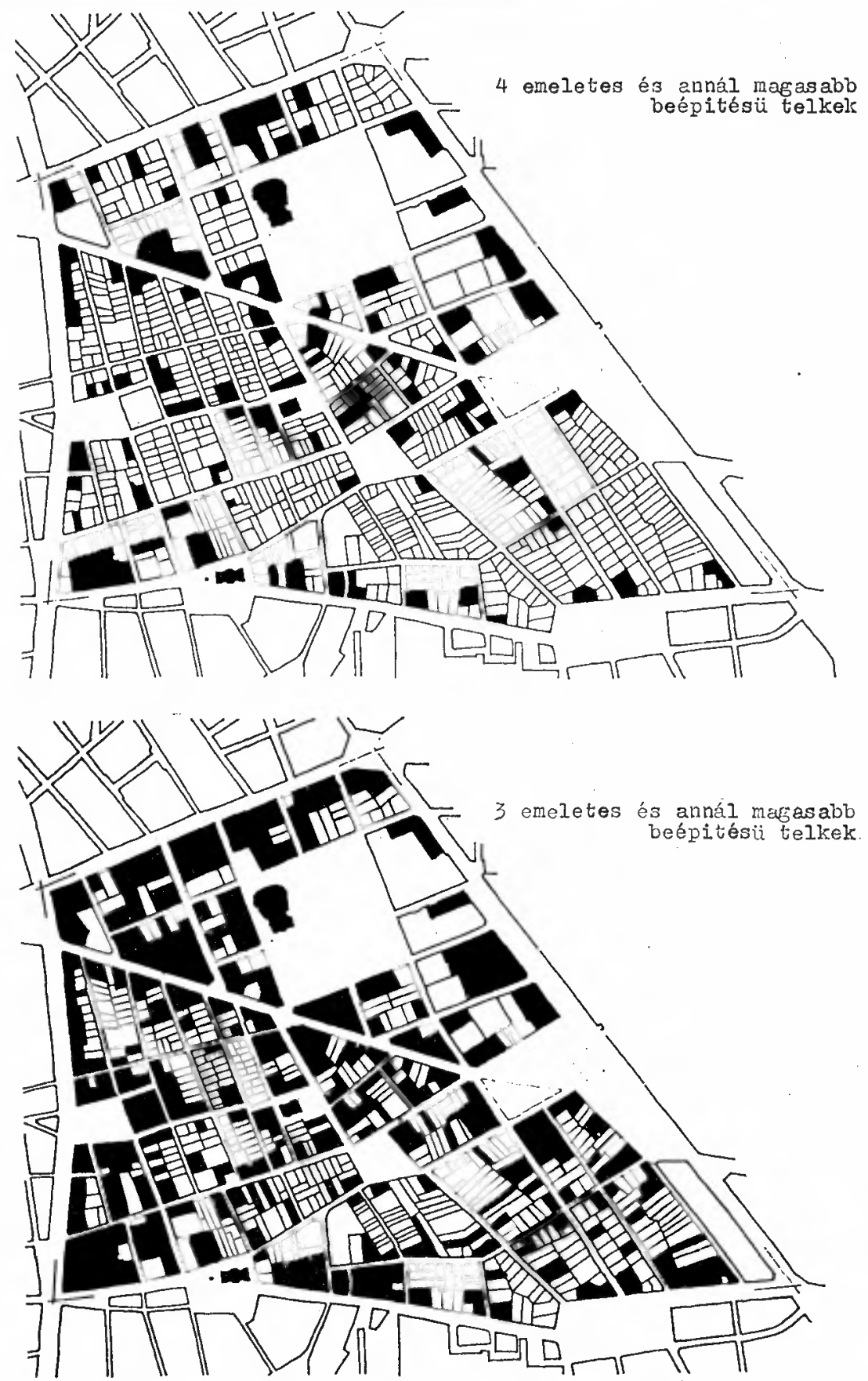

A beépités karaktere 
Perczel Anna : A Közép-Józsefváros északi területére készülő részletes rendezési terv programja

(Detailed plan and program of the Northern part of Central-Josephstadt in Budapest) Tér és Társadalom 6. évf. 1992/3-4. 89-162. $p$.
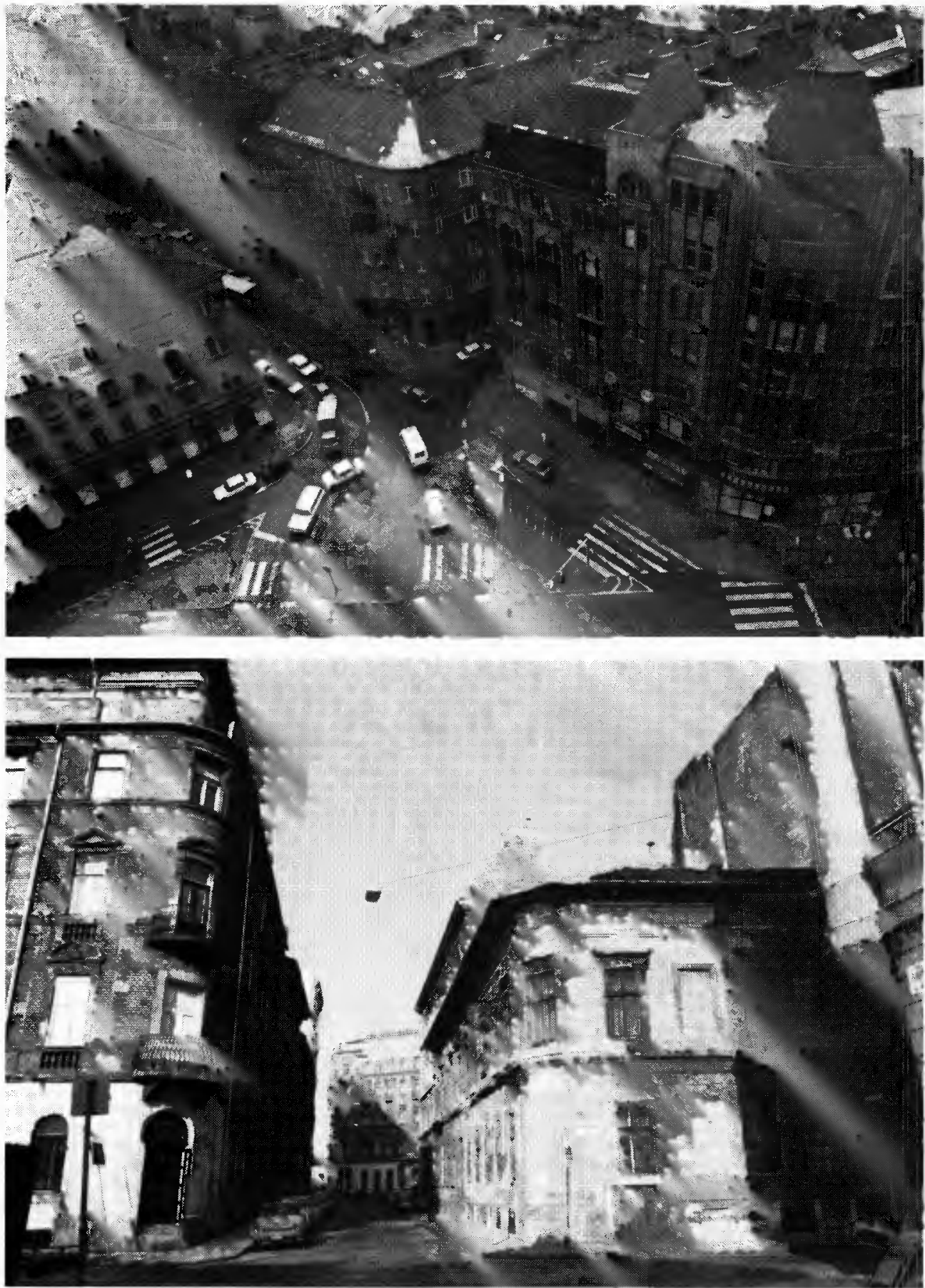

A Közép-Józsefváros a nagy kontrasztok városrésze, ahol egyszerre van jelen a nagyváros, a kisváros és a falu 
Perczel Anna : A Közép-Józsefváros északi területére készülő részletes rendezési terv programja (Detailed plan and program of the Northern part of Central-Josephstadt in Budapest)

Tér és Társadalom 6. évf. 1992/3-4. 89-162. p.

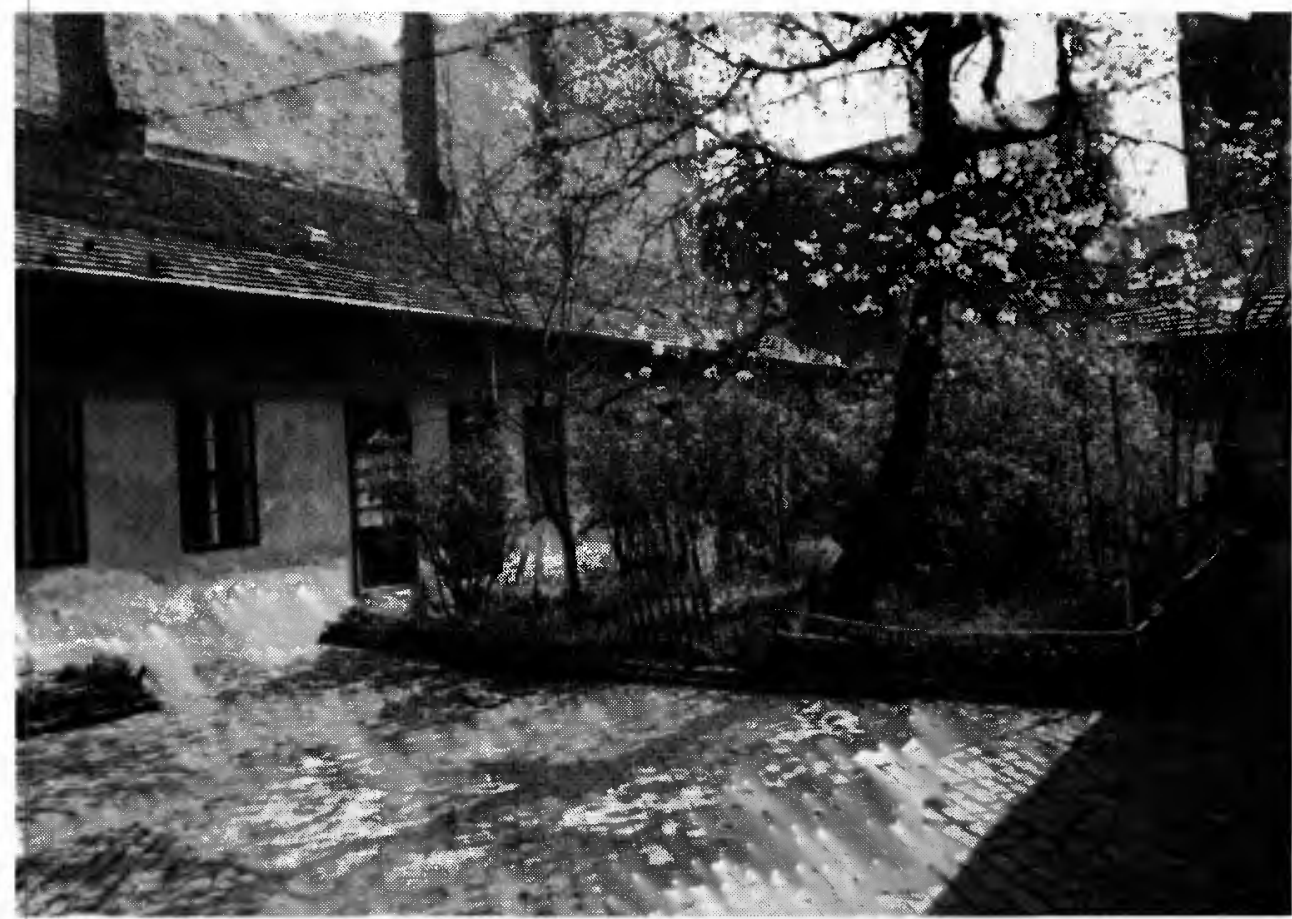

\section{A városrész mai helyzete, jellegzetességei}

A Józsefvárosnak e Nagykörúton kívül fekvố északi része, melyet két városból kivezetổ hajclani országút, a mai Rákóczi út és a Baross utca, valamint két körút, a hajdani városárok, városhatár mentén húzódó mai Fiumei út és a József körút határol, különös és feltưnően ellentmondásos világot képvisel a fớvároson, de a Józsefvároson belül is.

Addig amíg a Belsô-Józsefváros szinte homogén, egységes városrésznek tekinthetổ mind kialakulásában, mind beépítésében, mind társadalmi tradícióiban, addig a Közép-Józsefváros Északi része határozottan többféle, egymástól sokszor teljesen eltéró, bár egymáshoz szervesen illeszkedô, egymást átható és végülis összetartozó negyedból, környékbốl áll.

Ezek között van olyan is, mely egyedül csak itt található az egész fốvárosban és olyan is, amely a szomszédos városrészekkel rokon, azonos. De az északi rész nemcsak a BelsóJózsefvárostól különbözik ezáltal, hanem a Közép-Józsefváros déli részétól is, annak ellenére, hogy kialakulásuk, egész fejlôdésük, sớt városközpontjuk is közös volt, beépítési karakterük fltalában rokon. 
Perczel Anna : A Közép-Józsefváros északi területére készülő részletes rendezési terv programja

(Detailed plan and program of the Northern part of Central-Josephstadt in Budapest)

Tér és Társadalom 6. évf. 1992/3-4. 89-162. p.

$98 \quad$ Perczel Anna

TÉT 1992-3-4

Mi az, ami az egész Közép-Józsefuárosra általánosan jellemzô??

A József körút mentén még a Belvárost jelentô és folytató városrész a Fiumei út - Orczy tér környékén már a körút polgári világától élesen különbözố várost, munkások és hajléktalanok világát idézi.

A nagy kontraszt nemcsak a Közép-Józsefváros két pólusa között, de a városrész egy-egy utcáján, tömbjén belül is jellemzố.

Igen gyakori kép a belsổ utcákban és terek körül a négy-ötemeletes szecessziós bérház tövében álló, múltszázad végébốl ittmaradt földszintes polgárház, majd a háromemeletes eklektikus lakóépület mellett húzódó telephely, üres telek, üzemi épület és az ,,elôkelổ’ múltra visszatekintố polgári bérház mellett sorakozó ,,munkás-bérkaszárnya” is.

A lakóépületek, bérházak kapuján belépve a különleges szépségũ és hangulatú belsổ terek, udvarok, olykor gazdag növényzetũ, elvarázsolt kertek mellett ott találhatók a kétségbeejtốen sivár, sötét és dohos udvarok is.

Az országosan és fổvárosi szinten is jelentôs közintézmények, iskolák nagy száma is különös kontrasztot kölcsönöz ennek a leépülést sugárzó városnegyednek.

Akár jó és akár rossz, akár , ,elôkelô”’ és akár , ,szegény” világot jelentổ környékrôl, beépítésrổl, épületrốl van szó, a belsổ utcákra egyformán jellemzổ az elhanyagoltság, a leépülés. Mindenütt láthatók a városi élet elsorvadásának különféle jelei: a bezárt vagy raktárnak használt volt üzletek, mûhelyek, vendéglốk, kávéházak nyomai, sokszor üresen álló üzemi épületek. A leépülés látványához szorosan hozzátartoznak a tönkretett, díszeiktôl megfosztott épületek homlokzatai, belsổ terei, a vizes pincék, a leomló vakolat, a beszakadó-beázó tetôk, az aládúcolt függôfolyosók és lakások is.

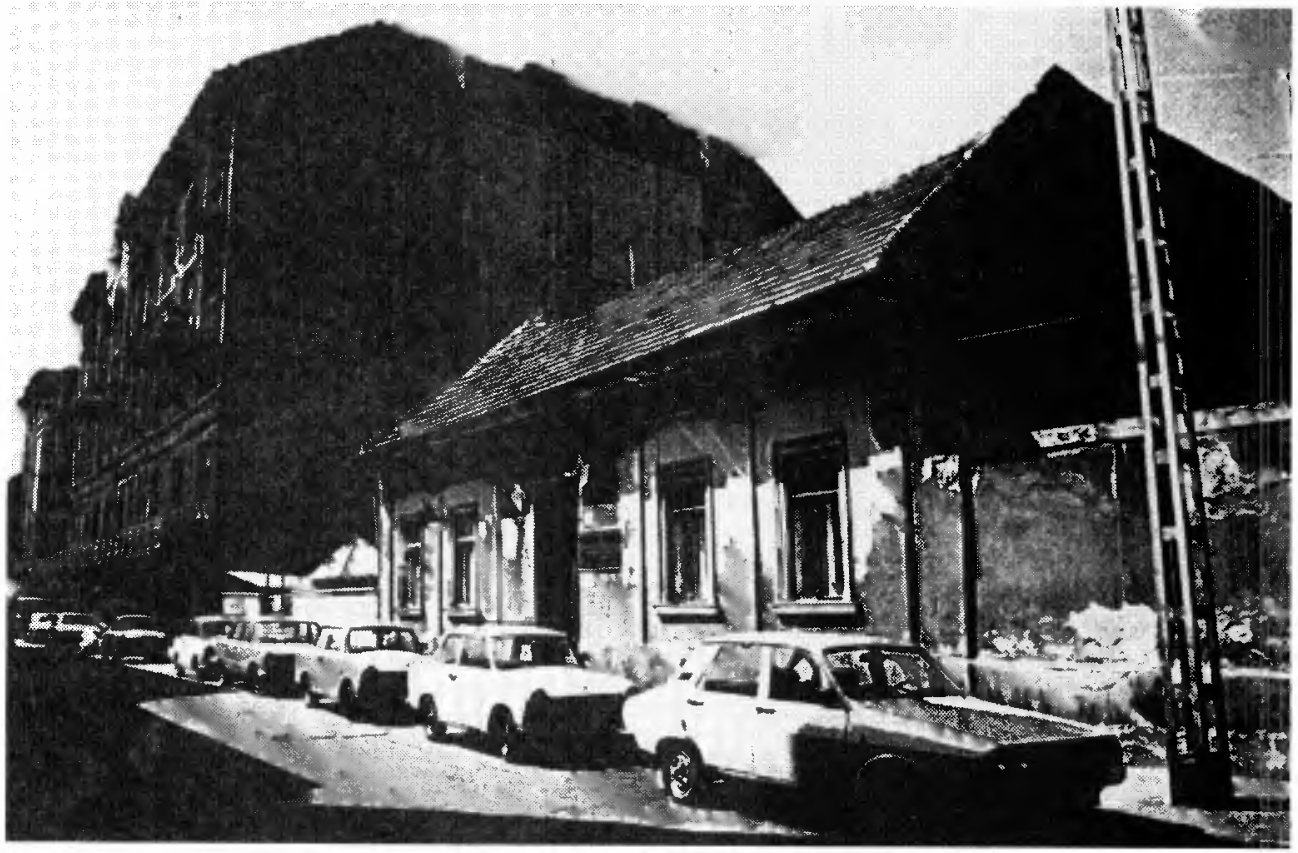


Perczel Anna : A Közép-Józsefváros északi területére készülő részletes rendezési terv programja (Detailed plan and program of the Northern part of Central-Josephstadt in Budapest) Tér és Társadalom 6. évf. 1992/3-4. 89-162. p.

Mi az ami sajátos, és csak erre a városrészre jellemzó?

A tradicionálisan megkülönböztethetô negyedek, beépítések sokfélesége, melyeket elsósorban a foglalkozás és életforma határozott meg, és határoz meg esetleg még ma is.

A volt zsibárus negyed / Teleki tér és Népszínház utca környéke

A prostituált negyed / Rákóczi tér és Mátyás tér környéke

A Rákóczi tér és környéke a századforduló óta a fớváros legnépesebb prostituált negyede, eredetileg sokkal kisebb területet érintett. A Conti utcától északabbra a József utcától délebbre már nem volt jellemzô. Ma Rákóczi tér-Mátyás téri súlypontokkal az egész környék területét behálózza.

A józsefvárosi gazdálkodók és iparosok lakó- és munkahelyei / Korai földszintes polgárházak, udvaron múhelyépülettel, istállóval

Külön negyede az iparosoknak ugyan a városrészben nincs, de a falusiasabb, kisvárosiasabb részeket jellemzi, ahol továbbra is megmaradt a sajátos józsefvárosi iparosság egy része: asztalos, bútorkészítô, kárpitos, lakatos, kôfaragó, hangszerkészítő stb.

Jellemző, hogy elsổsorban olyan iparos szakmák találhatók itt ma is, amelyek gyakorlására udvarra van szükség. Ez itt ma még mindig megtalálható.

Yállalkozók, kereskedôk lakó- és munkahelyei / Udvarházak, külvárosi paloták, udvaron álló kisüzemekkel, istállókkal stb.

A középosztály lakóhelyei / polgári bérházak

Az egységesebben, nagyvárosiasan beépült utcákban, a Köztársaság tér és a Népszínház utca környékén, a József körúton, a Rákóczi úton, a Baross utca egyes szakaszain, de gyakran elszórtan és önállóan is fellelhetôk a Belváros bérházaival vetélkedó igényes, gazdagon díszített lakoépületek komfortos, tágas, jó lakásokkal. 
Perczel Anna : A Közép-Józsefváros északi területére készülő részletes rendezési terv programja

(Detailed plan and program of the Northern part of Central-Josephstadt in Budapest)

Tér és Társadalom 6. évf. 1992/3-4. 89-162. p.

$100 \quad$ Perczel Anna

TÉT 1992-3-4

Munkások lakóhelyei / munkásbérkaszárnyák.

A külvárosok, elsôsorban Kốbánya gyáraiban dolgozó munkások egy része ezen a területen jutott olcsóbérú lakáshoz. A Népszínház utcától délre, a Nagyfuvaros utca-Dankó utca vonalától a Dobozi utcáig terjedổ területen szoba-konyhás lakások tömegét építették fel az 1880-as évektốl az elsổ világháborúig. Ezek a sokszor 80 szoba-konyhás lakást is magukba foglaló munkásbérkaszárnyák - komfort nélküli lakásaikkal, de azóta sokkal leromlottabb állapotban ma az egyik alapvetổ, megoldandó problémáját jelentik a területnek.

Városszerkezeti kettössége

A városrészt élesen kettéhasítja a Népszínház utca erôteljes átlós vezetése, mely térbeli és idốbeli határvonal is egyben.

A Népszinház utca-Fiumei út-Baross utca-József körút által határolt terület

Az organikus városfejlốdés során a XVIII. században kialakult utcavezetésével, tereivel, tömb- és telekosztásaival rendkívül izgalmas összetett, és sưrũ világot képvisel és önmagán belül még 4 szerkezetileg jól megkülönböztethetổ területból áll.

A Népszínház utca-Fiumei út-Rákóczi út által határolt háromszögü terület

Tudatos városrendezési-szabályozási elképzelések szerint alakult ki a volt állatvásár majd piactér területének felparcellázásakor a XIX. század közepén.

Széles utcáival, derékszögû́ utcahálózatával, nagyméretũ telkeivel, nagyvárosias, nagyvonalú beépítésével, közintézményeivel és közparkjával, a mai Köztársaság térrel, már a modern nagyvárost képviseli, és ezáltal az összes környezố városrésztốl különbözõ. 


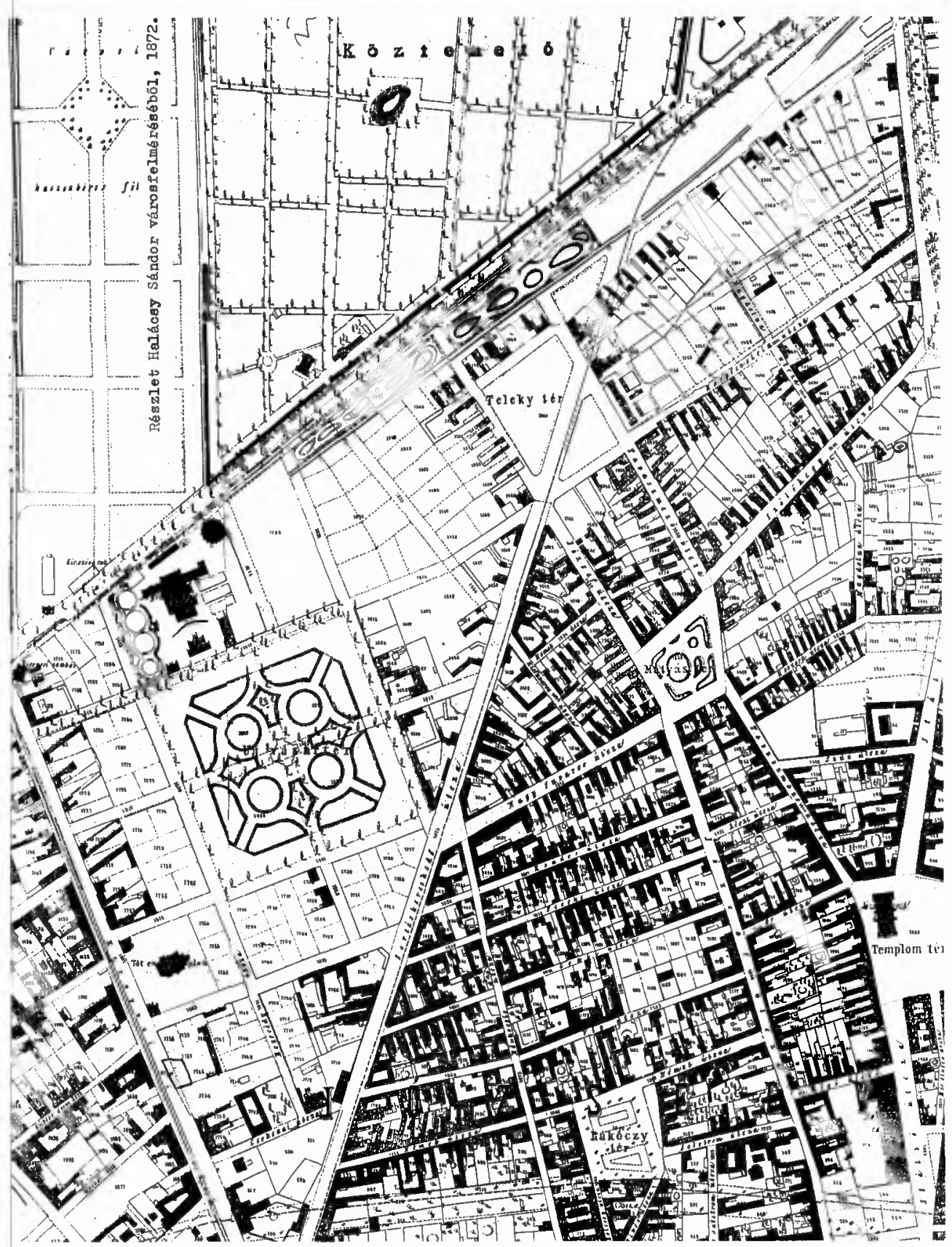

Halácsy Sándor 1873-as térképén kialakulásában jól látható a Közép-Józsefváros északi részének kettôs szerkezete, azállatvásár területének már szabályozott, de még beépítetlen területe és az organikusan beépitett városrész 
Perczel Anna : A Közép-Józsefváros északi területére készülő részletes rendezési terv programja

(Detailed plan and program of the Northern part of Central-Josephstadt in Budapest)

Tér és Társadalom 6. évf. 1992/3-4. 89-162. p.

102 Perczel Anna

TÉT 1992-3-4

A Keleti pályaudvar és a Józsefvárosi pályaudvar közelsége

A városrész fejlổdésére mindkettổ nagyhatású és meghatározó volt. Ma már ez a Józsefvárosi pályaudvarra egyáltalán nem mondható el.

A Keleti pályaudvar kisugárzó hatása ma is érvényesül, elsôsorban a Rákóczi út mentén.

A városias beépítés kontinuitásának teljes hiánya a Fiumei út túloldalán

A városrész különleges helyzete nem pusztán belváros és külváros közötti elhelyezkedésének kontrasztjából fakad, de abból is, hogy a Közép-Józsefváros északi része a külvárossal érintkezô Fiumei út túloldalán nem felparcellázott, városias beépítésũ területekbốl áll, henem szinte a szabadba fut ki. Itt jó idốre megszakad a városias kontinuitás, mert a városfejlốdés adott szakaszában e hajdani városhatáron kívüli területeket olyan nagy helyigényũ, közcélú városi funkciók foglalták el, mint a Keleti pályaudvar - Tattersaal - Lóversenypálya - Kerepesi úti Köztemetổ - Józsefvárosi pályaudvar - Ganz Vagon és Gépgyár. A városrész utolsó házsorával szemben itt a temetô fala húzódik.

A városi terek és parkok sokasága és sokfélesége, mely igen szokatlan jelenség a sürün beépittett pesti oldalon

A szomszédos városrészek, de az egész pesti oldal is városi térben, parkban szegény. Itt ezen a viszonylag kis területen több, még az organikus városfejlơdés során kialakult (Orczy tér, Kálvária tér, Teleki tér, Mátyás tér, Horváth Mihály tér) és több városrendezési eszközökkel szabályozott tér, illetve park is található (Blaha Lujza tér, Baross tér, Teleki tér, Rákóczi tér, Köztársaság tér, Harminckettesek tere).

Ez mégsem jelenti azt, hogy elegendố park és zöldterület lenne itt, hiszen a terek közül csak a Köztársaság tér az, amely már komoly, ökológiailag-környezetileg is jelentôs hatású zöldfelület. 
Perczel Anna : A Közép-Józsefváros északi területére készülő részletes rendezési terv programja (Detailed plan and program of the Northern part of Central-Josephstadt in Budapest)

Tér és Társadalom 6. évf. 1992/3-4. 89-162. p.

Városszerkezetet gazdagító kisebb térelemek igen nagy száma

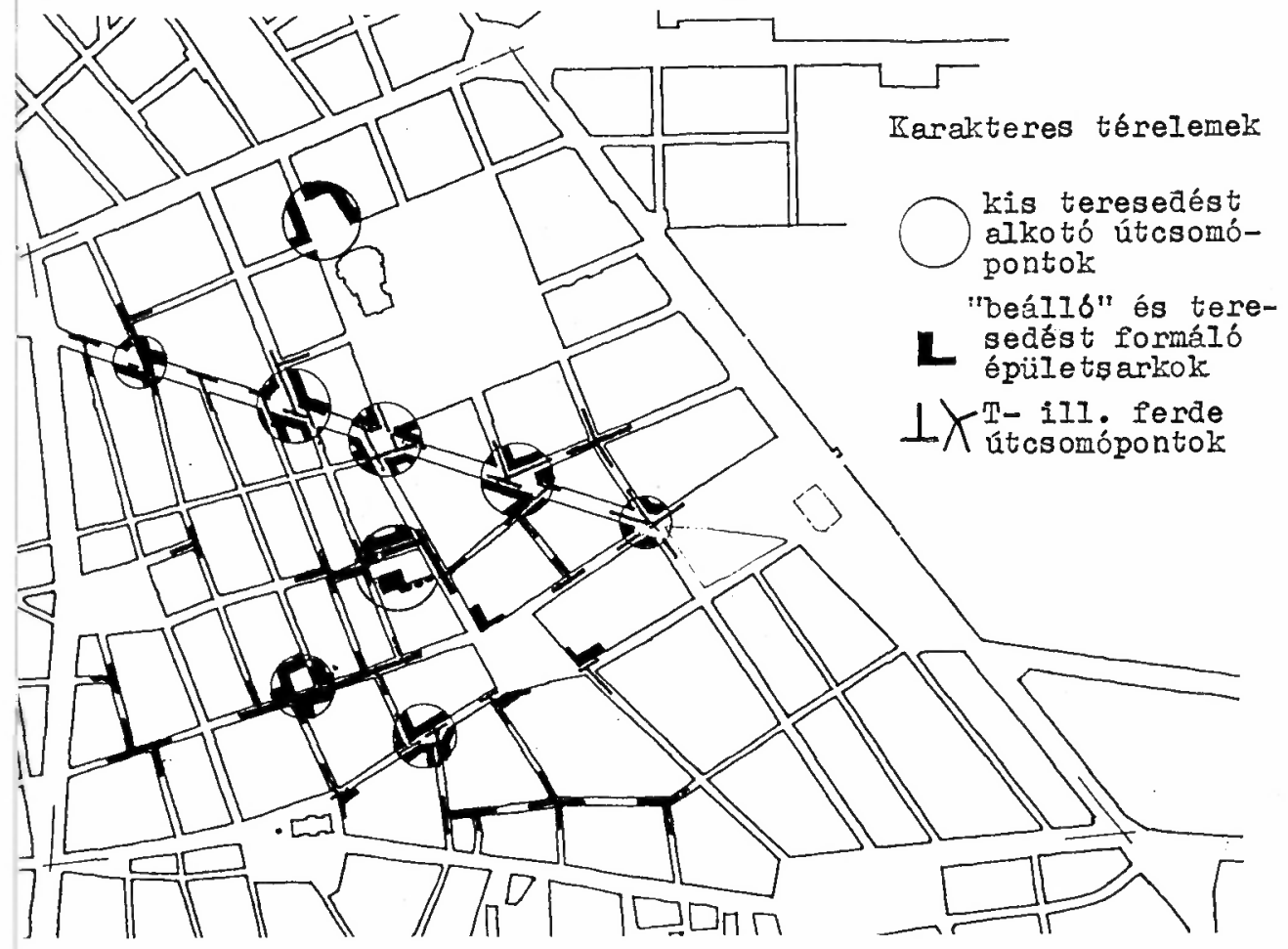

\section{A III emeletes bérházak dominanciája}

Ebben erốteljesen eltér az északi rész a délitốl, ahol a II emeletes épületek vannak túlsúlyban.

Ez talán a Rákóczi út és Üllổi út közötti presztízs, vonzerổ közötti különbségre vezethetố vissza.

Tradiciónális kisüzemek, mühelyek

Bár ez általánosan jellemzô az egész Közép-Józsefvárosra, itteni sajátosság, hogy ezek a kisüzemek többnyire nem az utcáról nyílnak, hanem az utcai lakószárny mögötti udvarból.

Gyakran üresek vagy raktározásra használják ôket.

Az üres, beépithetõ telkek igen magas aránya

Ez egyedülálló lehetổséget teremt a megújulásra, a meglévô épületek nagyobb részének megtartása mellett is. 
Perczel Anna : A Közép-Józsefváros északi területére készülő részletes rendezési terv programja

(Detailed plan and program of the Northern part of Central-Josephstadt in Budapest)

Tér és Társadalom 6. évf. 1992/3-4. 89-162. p.

104 Perczel Anna

TÉT 1992-3-4

A Népszínház utca

Az egész városban egyedülálló kialakulásával (az Alföldrốl a dunai révhez vezetố marhahajtó útvonal volt) átlós és határozott, a Körúttól a Teleki térig, majd a Temetốig vezetố vonalvezetésével, hegyes és tompaszögứ útkeresztezốdéseinél kialakult teresedéseivel, különleges saroképületeivel, üzleti életével, villamosával.

Különös az a helyzet is, mely építészeti nagyvonalúsága és mindennapi életének külvárosiassága között feszül és az az éles határoló szerep, mely az új — modernebb és a régi — hagyományosabb városrészek közötti helyzetébốl fakad.

Éles határoló szerepe mellett ugyanakkor nyílegyenes utat is jelent a Nagykörút belvárosi forgatagából a gyárak és a temetõ világa felé.

\section{A , városi házak"}

Az állatvásár felszámolása, kiköltöztetése után kialakult szabad területek egy részét a város megtartotta. Ezen a Köztársaság tér és Fiumei út közötti területen a fôváros üzemelését és egészségügyi, szociális ellátását is szolgáló intézményeken kívül szociális bérlakásokat épített a fỗváros az 1910-es években. Ezek voltak a ,,városi házak”. Annak ellenére, hogy olcsó bérũ lakásoknak épültek, igényesek és korszerúek voltak. Ilyen akciókra szükség lenne ma is.

\section{A villamos}

Talán egyik körúttól kifelé elhelyezkedố városrésznél sem jellemzô ennyire a villamos látványa és a villamoshoz kapcsolódó élet.

Ennek oka, hogy a városból kivezetố fố közlekedési utakon, például a Rákóczi úton, Üllôi úton is megszüntették a villamosjáratokat, de itt a Népszínház utcában szerencsésen megmaradt. 
Perczel Anna : A Közép-Józsefváros északi területére készülő részletes rendezési terv programja

(Detailed plan and program of the Northern part of Central-Josephstadt in Budapest) Tér és Társadalom 6. évf. 1992/3-4. 89-162. p.
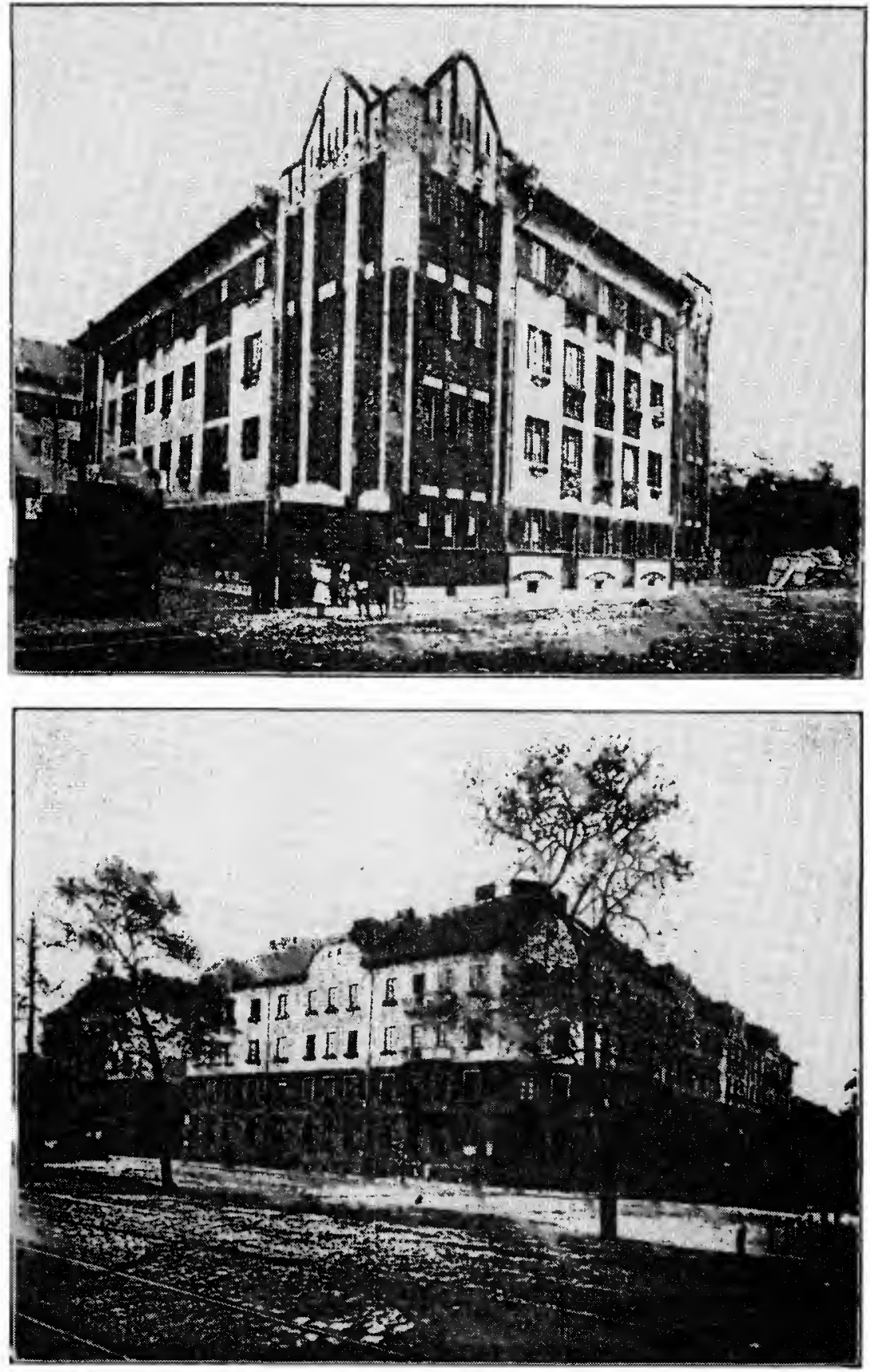

A ,városi házak" az Alföldi utcában és a Fiumei üton 
Perczel Anna : A Közép-Józsefváros északi területére készülő részletes rendezési terv programja

(Detailed plan and program of the Northern part of Central-Josephstadt in Budapest)

Tér és Társadalom 6. évf. 1992/3-4. 89-162. p.

\section{Lakóépületek és lakásviszonyok}

A városrész különössége-sajátossága lakóépületeinek egyedülálló és szokatlan változatossága is. Ez a változatosság igaz beépítésük, szintszámuk, építészeti koruk-stílusuk-értékük, lakásösszetételük vagy társadalmi megítélésük szempontjából egyaránt. De igaz belsố kertjeik vagy annak hiánya, sötét udvaraik vagy tágas belsố tereik tekintetében is.

Mindez azt jelenti, hogy itt, a fôvváros közepén, feltūnően változatos, sokszor a szomszédos városrészektól is teljesen eltérô lehetôségek adódnak a meglévó lakóépületek adottságai révén. De a lakóépületek nagy részét minden szépségük és építészeti értékeik ellenére, az igen erôs leépülés, rossz állapot és a lakások jelentôs részének komforthiánya teszi elfogadhatatlanná, olykor taszítóvá.

A lakosság kb. 45\%-a 15-30 $m^{2}$-es komfort nélküli, vagy szükséglakásban él, sokszor vizes, - sötét, lakásnak nem is nevezhetố helyiségekben!

Építészeti-történeti-városképi szempontból azonban nem lehet másképp gondolkodni, mint e lakóépületek többségének megtartásával. Gazdaságilag sem valószínủ, hogy ma kb. 15600 db lakásnak közel a felét egyszerre csak meg lehetne szüntetni.

Nem lehet ilyen durván cselekedni azért sem, mert a romlás ellenére sem lenne szerencsés jól mưködố társadalmi kapcsolatokat, szomszédságokat szétverni. Összetettebben kell végiggondolni, mi is lehet a jövôjje e városrész lakóépületeinek-bérházainak és ezáltal lakóinak?

Mindez nemcsak a várható rehabilitáció, de a már zajló lakáseladások, privatizációs eljárások során is differenciáltabb döntéseket igényel.

A társadalmi folyamatok vizsgálatai során egyértelmûen kiderült, hogy a városrész leépülésében döntố és egyre nagyobb szerepet játszik a lakások itt tömegesen elôforduló komforthiánya. Egy évszázaddal ezelổtt, de még a háború utáni években sem volt ez a tény oly anakronisztikus és elfogadhatatlan, mint ma, a XX. század végéhez közeledve.

Sốt, a mai helyzet sokkal rosszabb, hiszen ezeket a tulajdonosaiktól elvett épületeket az elmúlt 50 év során egyszerúen sorsukra hagyták, kitéve ốket a folyamatos, egyre gyorsuló pusztulásnak.

A megújulás lehetôsége ebben a városrészben ezért meghatározóan a lakóépületek és lakások rehabilitációján múlik.

Ahhoz azonban, hogy valódi változásokra lehessen itt számítani, nemcsak régi lakóházak és lakásaik rendbehozására, de nagyszámú új lakás építésére is szükség lesz.

A lakóépületek-bérházak sorából már itt is fel szeretnénk hívni a figyelmet a városrész legelsô, - késốklasszicista-romantikus - koraeklektikus korszakának feltétlenül védendô, de veszélyeztetett helyzetú földszintes és I. emeletes épületeire. Megtartásuk a Józsefváros sajátos hangulatának - karakterének megórzése mellett, a lakólehetôségek egyedülálló sokszínũségét is jelentené. 
Perczel Anna : A Közép-Józsefváros északi területére készülő részletes rendezési terv programja

(Detailed plan and program of the Northern part of Central-Josephstadt in Budapest)

Tér és Társadalom 6. évf. 1992/3-4. 89-162. p.

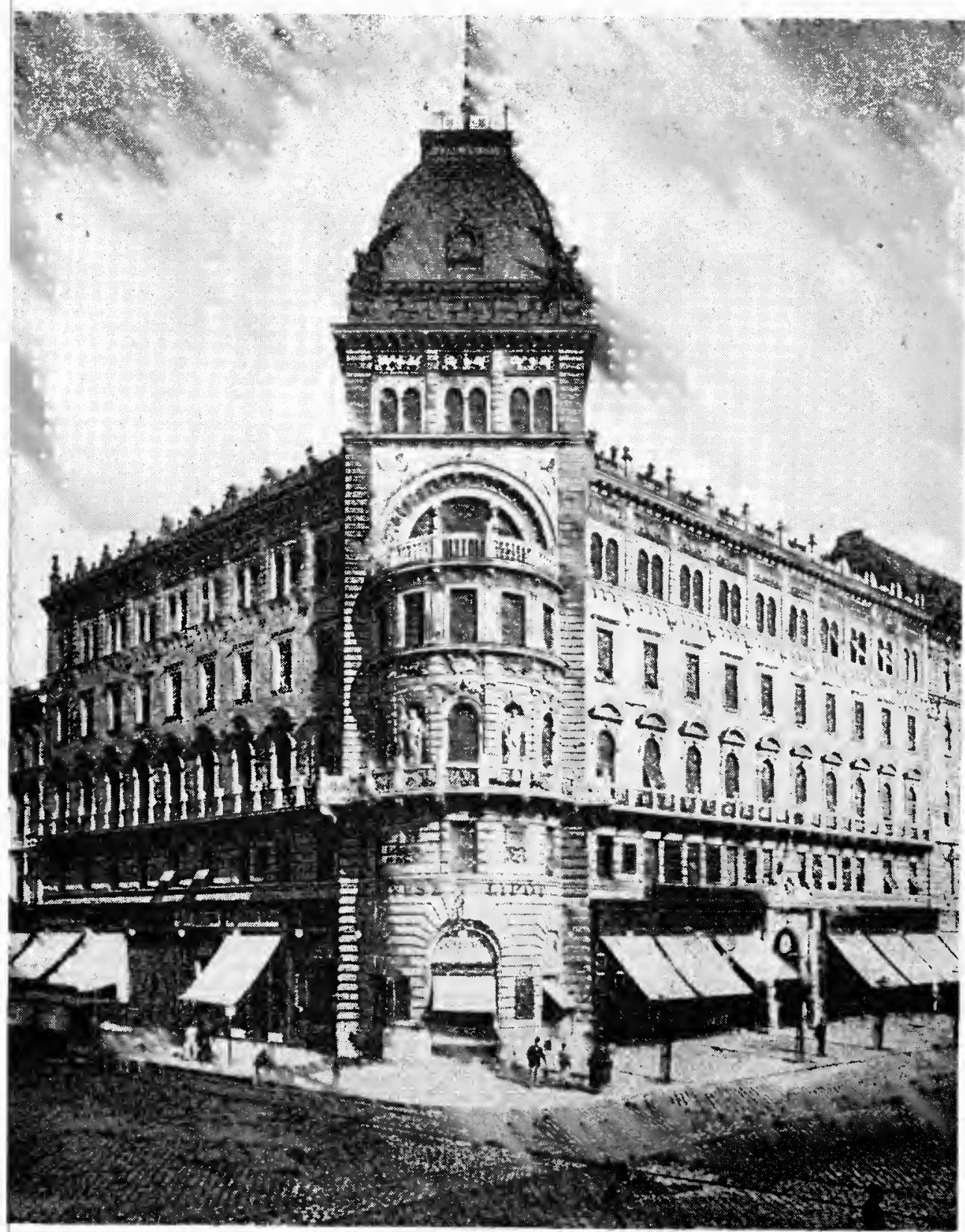

Elegáns nagyvárosi bérház a Közép-Jozsefvárost övezô, egységesen beépített fóútvonalon 
Perczel Anna : A Közép-Józsefváros északi területére készülő részletes rendezési terv programja

(Detailed plan and program of the Northern part of Central-Josephstadt in Budapest)

Tér és Társadalom 6. évf. 1992/3-4. 89-162. p.

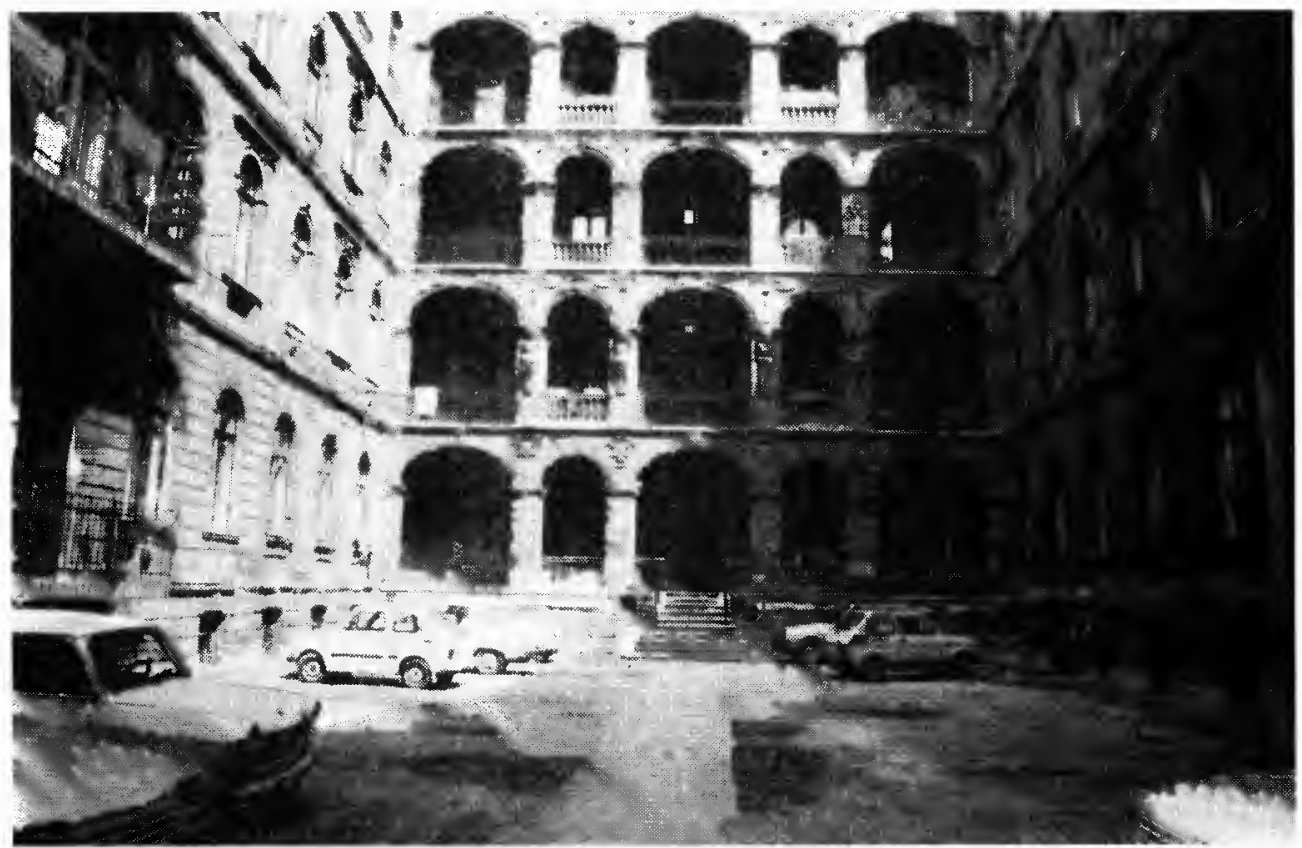

Andrássy üt környéki épületekkel vetekedó nagyvárosias polgári bérház (Bezerédi utca 6.)

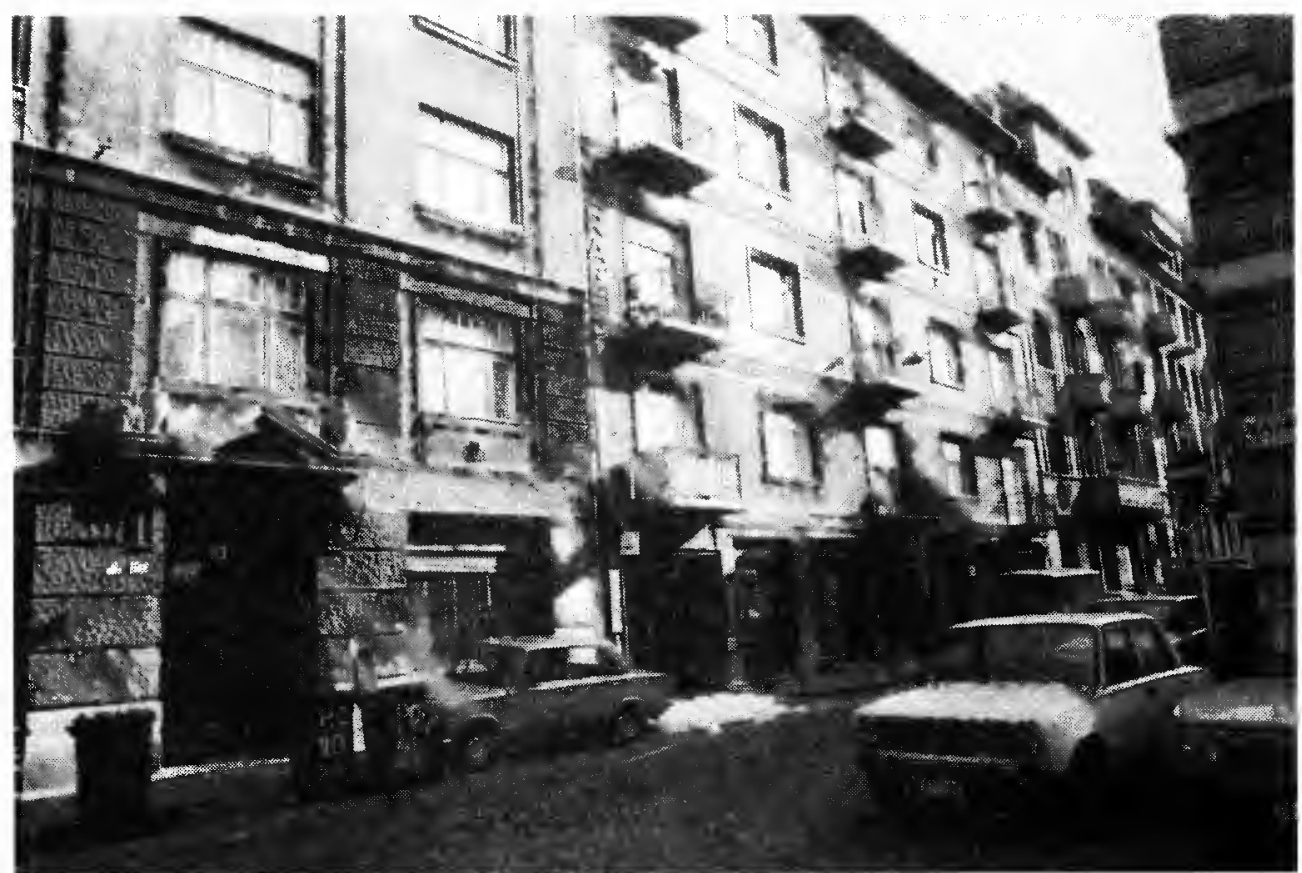

Háború elôtt épült , ,modern" bérházsor a Vásárcsarnok mögött (1932) (Víg utca 20., 22., 24) 
Perczel Anna : A Közép-Józsefváros északi területére készülő részletes rendezési terv programja

(Detailed plan and program of the Northern part of Central-Josephstadt in Budapest) Tér és Társadalom 6. évf. 1992/3-4. 89-162. p.
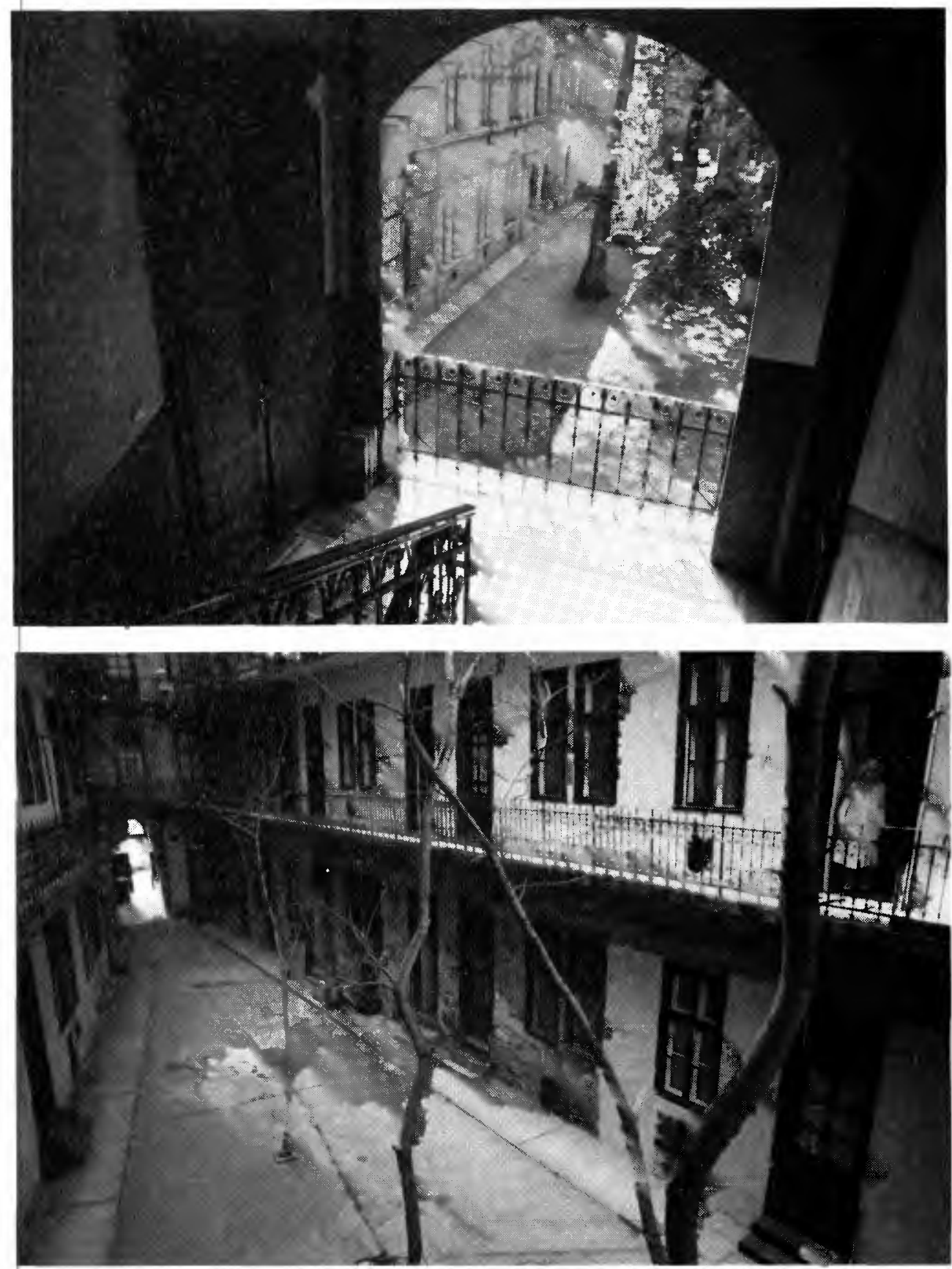

A Rákóczi útról nyiló Luther udvar, ,elókelôn' komfortos és a Mátyás tér, ,szegény” szoba-konyhás világa 
Perczel Anna : A Közép-Józsefváros északi területére készülő részletes rendezési terv programja

(Detailed plan and program of the Northern part of Central-Josephstadt in Budapest)

Tér és Társadalom 6. évf. 1992/3-4. 89-162. p.

110 Perczel Anna

TÉT 1992-3-4

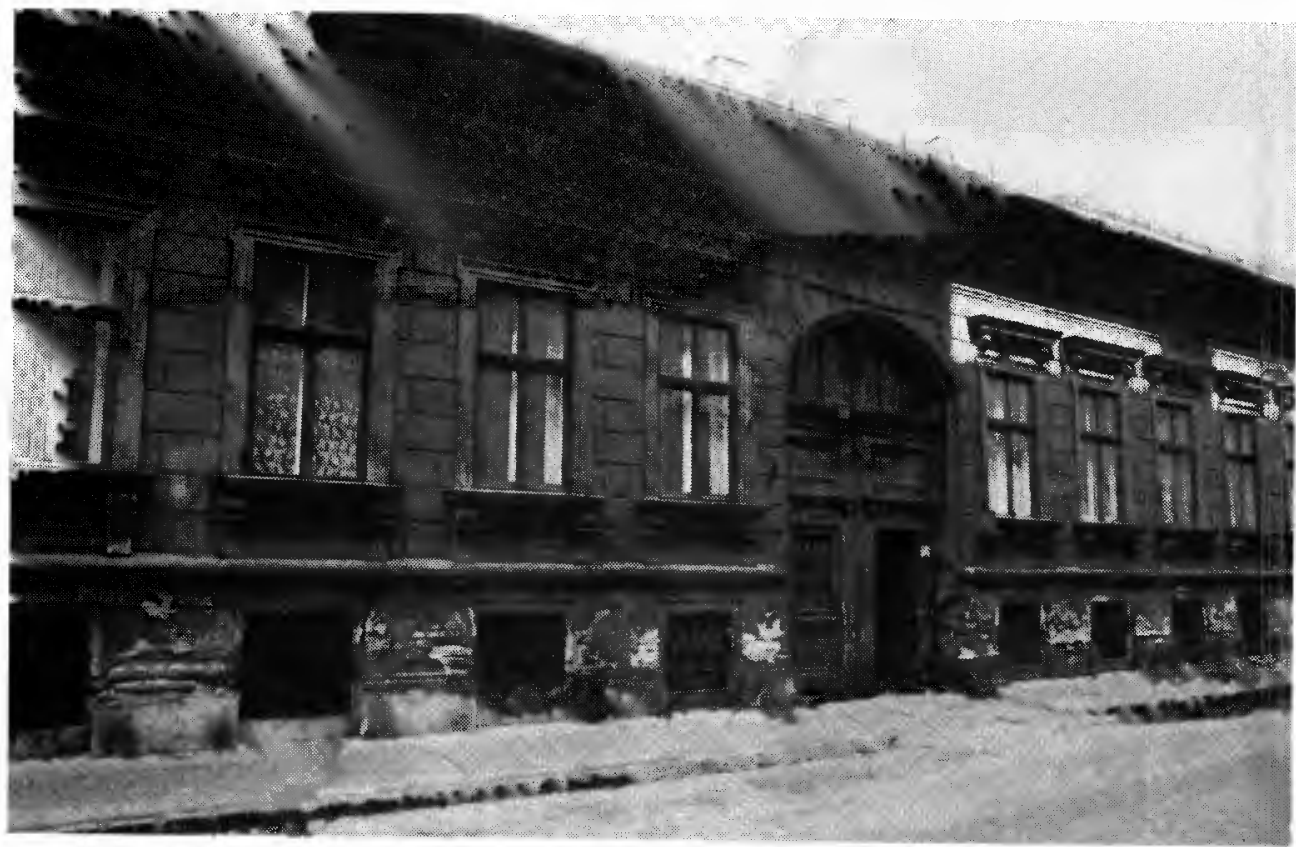

A kisvárosias időszak megmaradt beépitése szoba-konyhás lakúsok sorával (1875) (Lujza utca 2.)

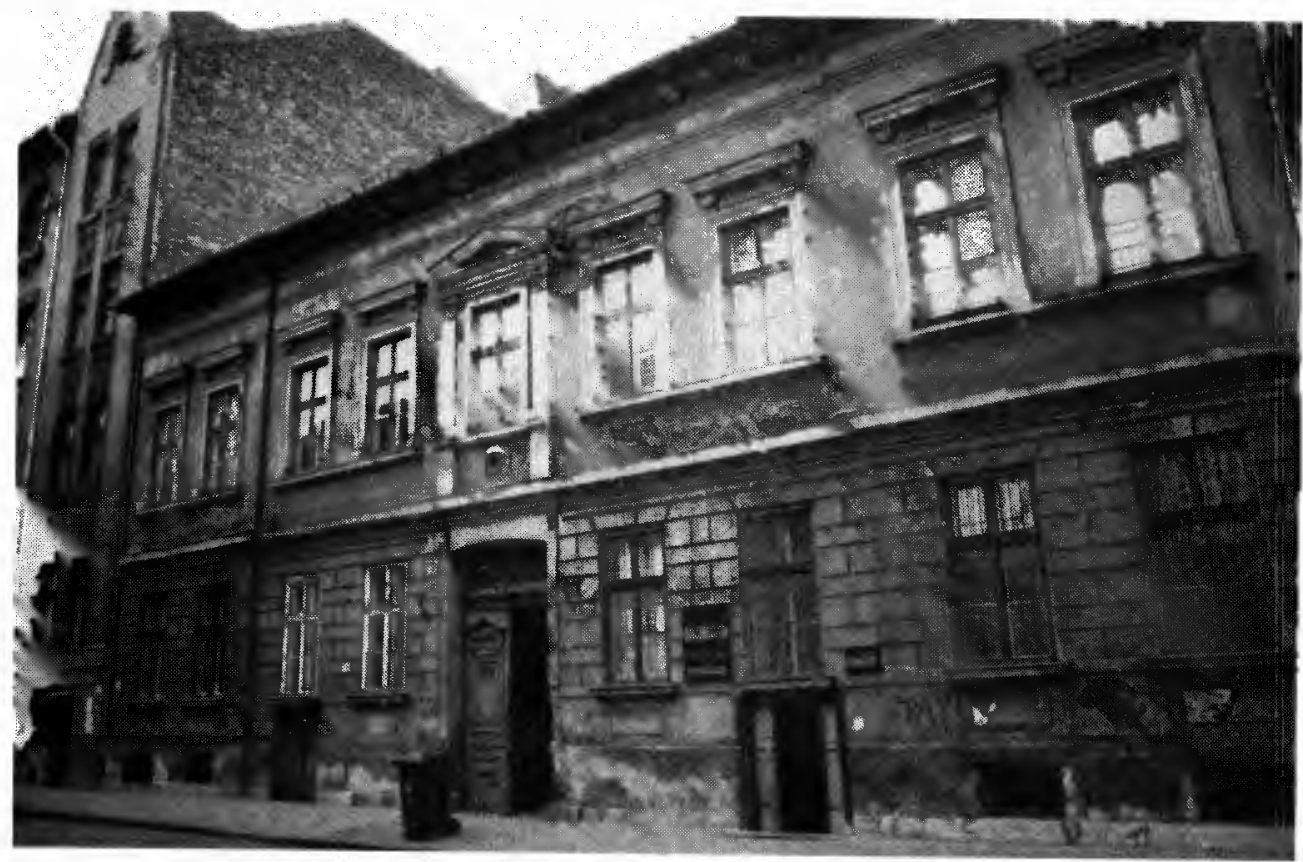

11 tengelyes ,,iparos ház”, széles telken, mély udvarral, komoly mühelyépülettel, kevés és jó lakással (1885) (Magdolna utca 4.) 
Perczel Anna : A Közép-Józsefváros északi területére készülö részletes rendezési terv programja

(Detailed plan and program of the Northern part of Central-Josephstadt in Budapest) Tér és Társadalom 6. évf. 1992/3-4. 89-162. p.

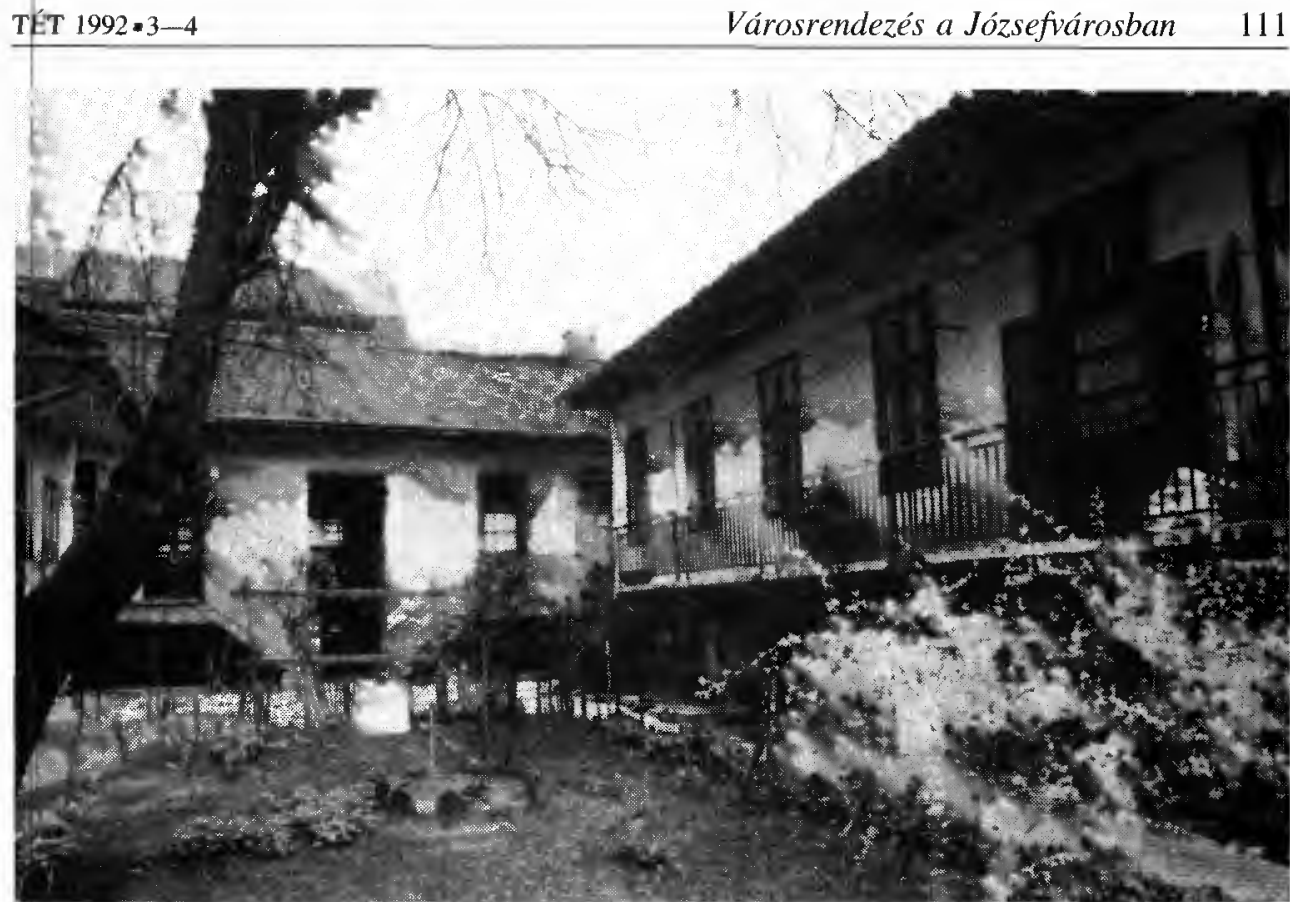

Arvíz utáni utcafeltöltések elốt épített u.n. elsüllyedt lakóház, falusias hangulat, komfortnélküli lakások (1857 körül) (Lujza utca 34.)

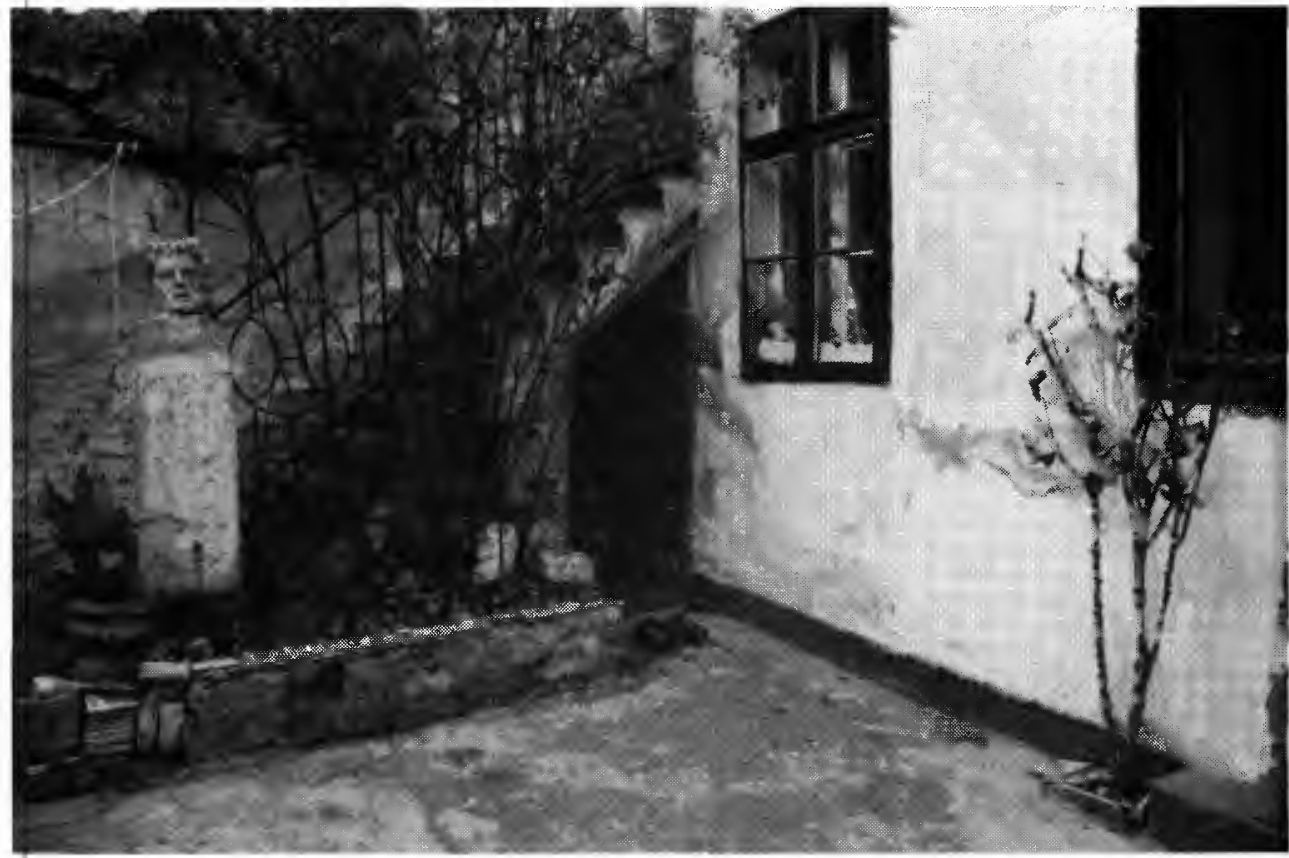

Földszintes magánház, komfortos lakás, oázisszerú életlehetốsége a nagyvároson belül (Auróra utca 21.) 
Perczel Anna : A Közép-Józsefváros északi területére készülö részletes rendezési terv programja

(Detailed plan and program of the Northern part of Central-Josephstadt in Budapest)

Tér és Társadalom 6. évf. 1992/3-4. 89-162. p.

\section{Középületek, intézmények, ellátás}

E leépülést sugárzó városnegyednek további paradoxonja középületeinek, intézményeinek, iskoláinak nagy száma, igényessége és feltűnôen változatos struktúrája.

Ez szinte egy önálló város!

Van pályaudvara és temetổje, feltửnốen sok iskolája*, szállodája. Van temploma, vásárcsarnoka, piaca, de van színháza, mozija, sốt operája és börtöne is.

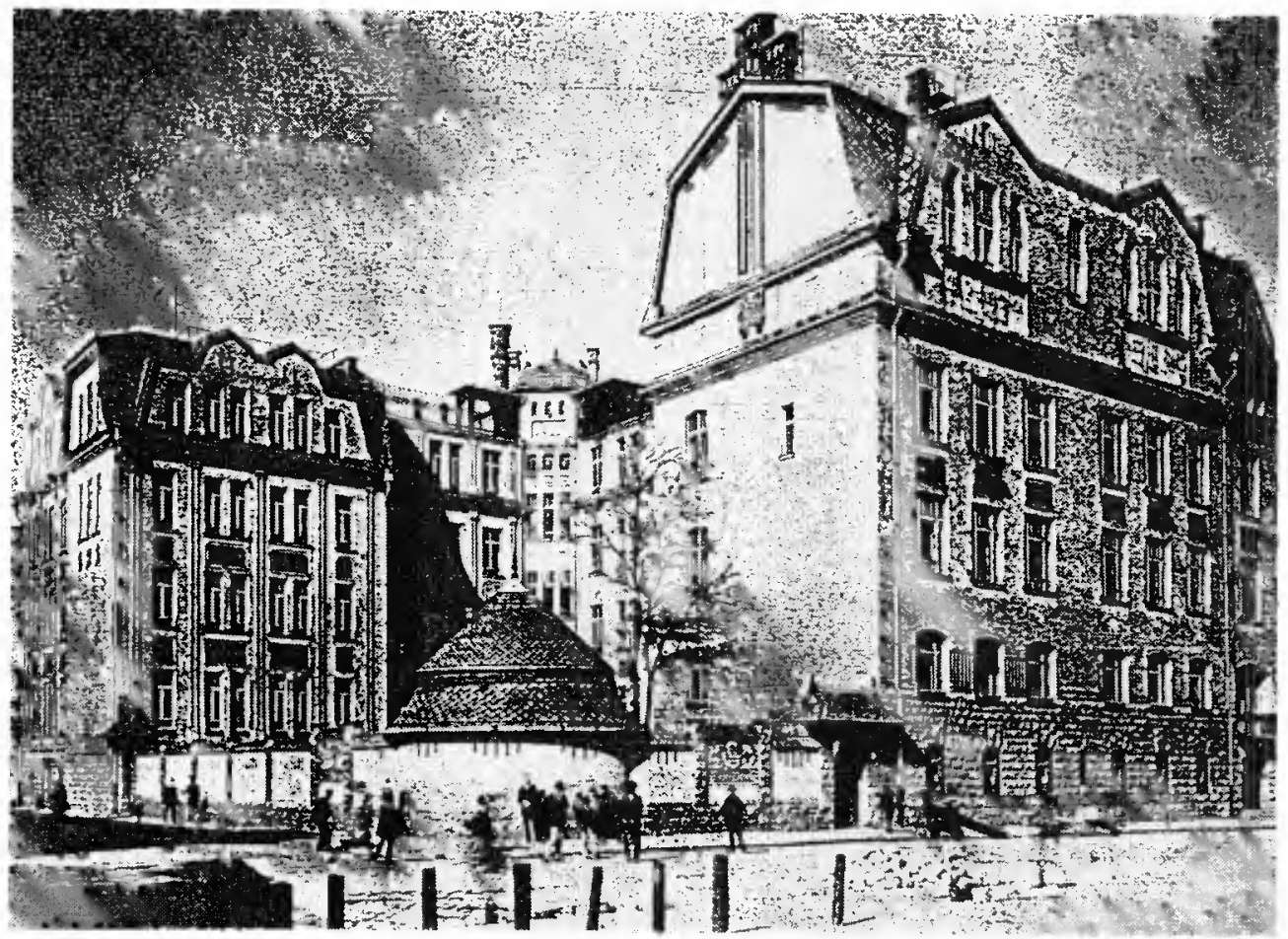

A városrész iskoláinak egyik legszebbike a Köztársaság tér sarkán épült fel szecessziós stílusban

*A városrész iskoláiba járó diákok száma több mint 11 ezer, a városrészben élớk száma 35600 fo. 
Perczel Anna : A Közép-Józsefváros északi területére készülő részletes rendezési terv programja (Detailed plan and program of the Northern part of Central-Josephstadt in Budapest)

Tér és Társadalom 6. évf. 1992/3-4. 89-162. p.

Területén helyezkedik el az egész fơváros múködését szolgáló közüzemek központjainak nagy része. Itt található az Országos Baleseti Intézet, az Országos Társadalombiztosító Székháza, a Józsefvárosi Telefonközpont, de a Nemzeti Oktatási Továbbképzés Központja, és a fơváros Pedagógiai Továbbképzó Intézete is.

Elgondolkodtató, miért van az, hogy mindezen jelentốs közintézmények jelenléte mégsincs igazán hatással a városrész sorsának alakulására, az itt éló emberek életére? Nem értékelik fel környezetüket, szinte szigetszerũ elzártságban mǘködnek egy számukra idegen világban!

Miként lehetséges, hogy miközben a Józsefvárosban mứködik a fốváros legjobb, legkiemelkedốbb gimnáziuma, ez az a városrész is, ahol a legalacsonyabb a fôvárosban az értelmiségiek, szellemi foglalkozásúak aránya?

Elsősorban a Józsefváros, de az egész fốváros kialakulására is jellemzố sajátos, szaggatott, meg-meginduló, majd mindig elakadó városfejlôdés vezetett oda, hogy miközben e városrészben megépültek e jelentổs közintézmények és mellettük elszórtan megindult a nagyvárosias bérházak kiépülése is, a városrész teljes átalakulására sohasem kerülhetett sor.

Különösen igaz ez a századforduló elốtti és utáni évek nagyszabású városfejlesztési elképzeléseire, majd az ezt követổ, a két világháború közötti idôszakra esố, teljes stagnálásra. A háború utáni államosítások és politikai-társadalmi átalakulások pedig szinte teljesen elsorvasztották és felszámolták éppen azokat a kisebb, a városrész mindennapi életéhez kapcsolódó sokszínũ ellátást, mely élổ módon egészíthetné ki, kapcsolhatná össze e komolyabb intézmények életét a városrész lakóinak életével. De egyben kicsúszott ezek alól az intézmények alól pontosan az a társadalmi-polgári háttér is, melyre felépítették ốket.

A mai helyzet végülis az, hogy e rendkívül sokféle és jelentổs középület jelenléte mellett hiányzik szinte minden, vagy csak hiányosan van jelen mindaz, ami a városrész lakóinak életéhez közvetlenül kapcsolódhatna.

- Egyáltalán nincs például bölcsổde, rossz vagy hiányos a szociális ellátás. Az öregekról yaló gondoskodás bár létezik, de nem elegendó és sokszor erre a célra alkalmatlan üzlethelyiségekben található.

- A helyi kisebb közösségeknek szóló kulturális lehetôségek egyszerũen nem léteznek többé.

— Feltûnō, hogy az itt különösen nagy számban élổ cigány kisebbségnek nincs valódi otthona, központja!

-Óvoda ugyan van, de nem jó területi elosztásban, és általánosan 20\%-os túlterheltséggel mứködốen.

- Ugyanez mondható el az általános- és a középszintú iskolákról is, ahol ezen kívül sokszor nincs udvar, kert és tornaterem!

- Nem látjuk megfelelổnek az orvosi rendelớk elhelyezkedését sem. A városrész közepén, az Auróra utcában, ugyan felépült egy új központi rendelổintézet, de véleményünk szerint, több kisebb, elszórtabban elhelyezkedố rendelôre is szükség lenne ebben az igencsak elöregedett yárosrészben.

- A hajdani híres vendéglátásnak nyoma sincs. A belsổ utcákban szinte semmilyen vendéglö, kávéház, cukrászda nem található, csak újonnan nyitott pince-borozók.

- A szolgáltatások, üzletek lassan majd újra birtokba veszik a belsố utcák élettelen földszintjeit, de feltứnó, hogy mennyire ritka és csak a fớtvonalakon található a mindennapi élet olyan kelléke, mint a gyógyszertár és a posta. 
Perczel Anna : A Közép-Józsefváros északi területére készülő részletes rendezési terv programja

(Detailed plan and program of the Northern part of Central-Josephstadt in Budapest)

Tér és Társadalom 6. évf. 1992/3-4. 89-162. p.

114 Perczel Anna

TÉT 1992:3-4

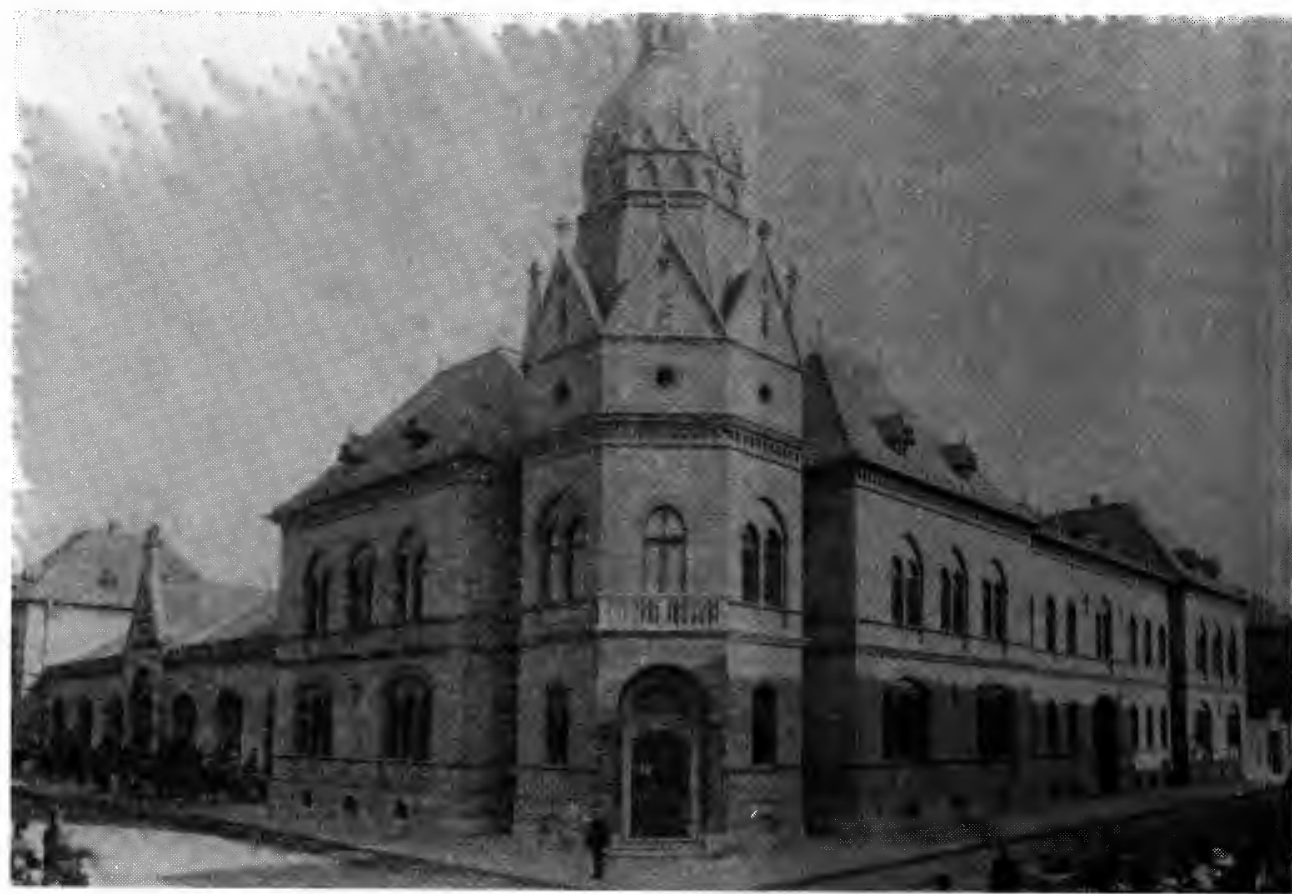

A Fơvárosi Tüzoltóság épülete (1895)

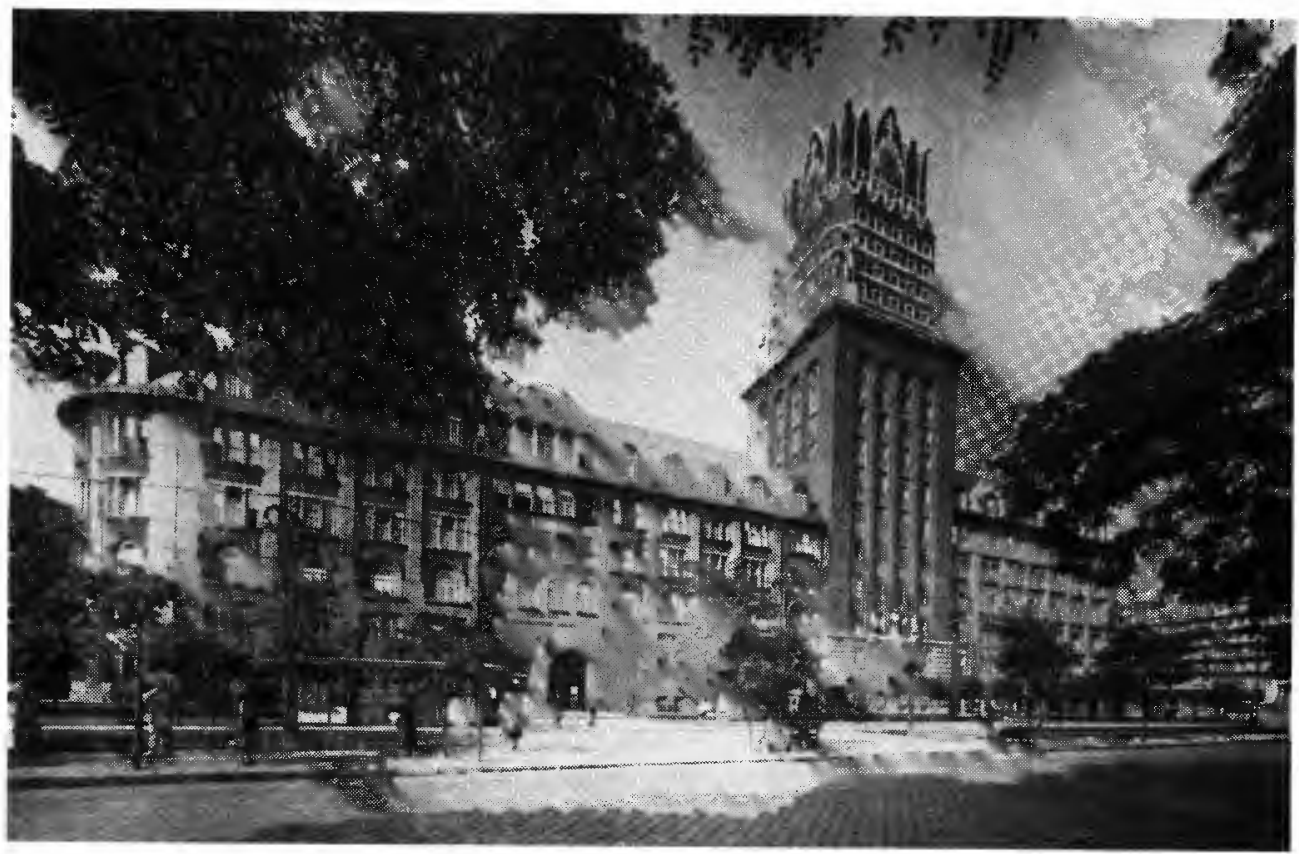

Az Országos Társadalombiztositó Intézet Székháza (1912-1932) 
Perczel Anna : A Közép-Józsefváros északi területére készülő részletes rendezési terv programja

(Detailed plan and program of the Northern part of Central-Josephstadt in Budapest) Tér és Társadalom 6. évf. 1992/3-4. 89-162. p.

TÉT 1992-3-4

Városrendezés a Józsefvárosban

115
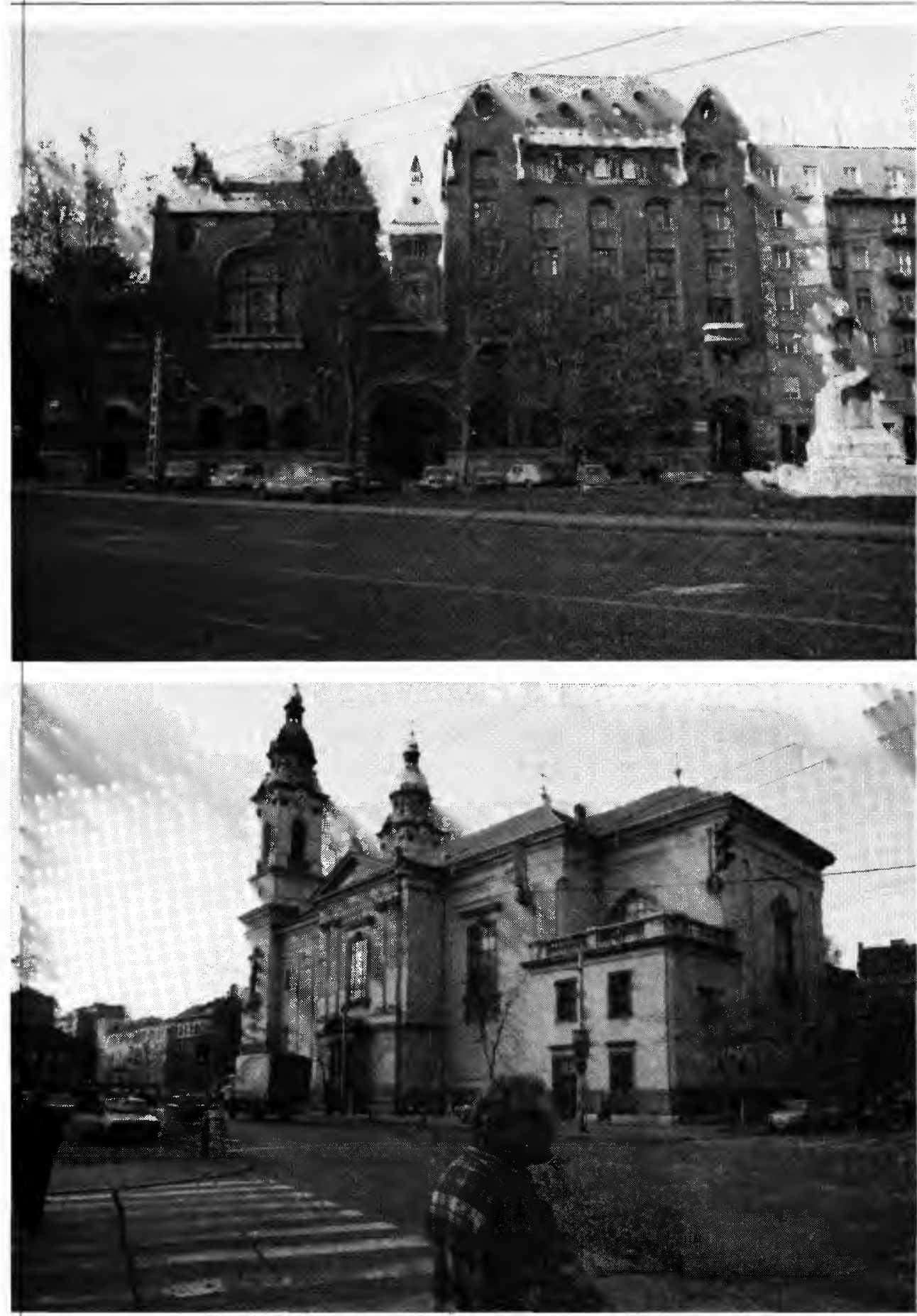

A Józsefuárosi Telefonközpont és a Józsefuárosi Plébánia templom 
Perczel Anna : A Közép-Józsefváros északi területére készülő részletes rendezési terv programja

(Detailed plan and program of the Northern part of Central-Josephstadt in Budapest)

Tér és Társadalom 6. évf. 1992/3-4. 89-162. p.

116 Perczel Anna

TÉT 1992-3-4

- A lakások kb. 45\%-a komfort nélküli, mégsincs közfürdó!

- Hiányzik minden, ami a sporttal kapcsolatos!

- A városrész leszakadó részén (C-jelữ területén) pedig egyáltalán nincs semmi óvodán, éjjeli szálláshelyen és öregek otthonán kivül. Itt még általános iskola sincs. Ez egyértelmũen a ,harmadik világ".

\section{Új jelenségek}

- Az egyházi visszaigénylések révén több épület kerül vissza eredeti tulajdonosához, eredeti funkciójába, melynek során nemcsak iskolákkal, óvodákkal, kollégiumokkal bốvül, gazdagodik majd ez a városrész, de a különbözổ egyházak jelenlétének erốsödése is pozitivan hathat majd.

- Az utóbbi két évben több társadalmi, vallási közösség kért és kapott helyet itt. Közülük a legjelentôsebb a Metodista-egyház evangéliumi egyházközösségének Dankó utcai elhelyezkedése.

- A Szigetvári utcában a Baross utcához közeli két telken most épül fel két új külföldi érdekeltségũ irodaház.

- Egyre-másra nyî́nak újra a bezárt vagy lakásnak, raktárnak használt, földszinti volt mứhelyek és üzletek. (Ez azonban elsổsorban az A jelũ területre jellemzõ.)

- Nem feltétlen pozitiv jelenség - különösen nem fơútvonal esetében - a PEEP-SHOW-k, játéktermek egyre nagyobb száma. Igen nagy bajnak tartjuk ezt olyan esetben, ha volt kávéház, vendéglô, és abszurd módon templom kerül ebbe a helyzetbe (BINGÓ TEREM)!

- Többszörös metamorfózison esett át - „,megfelelổen” képviselve a változó idóket - a József körút hajdani híres két kávéháza, a SIMPLON és a BODÓ kávéház is, ahol az ötvenes években önkiszolgáló étterem-büfé, most McDONALD étterem nyîlt. E legutolsó átváltozás különös tragédiája csak az, hogy a környéken éló embereknek végképp megszưnt minden lehetôségük az olcsó étkezésre.

- Feltūnố új jelenség az egész városban, de itt is, a kínai vendéglók megjelenése.

- A belsố utcák leggyakoribb ,új eseménye” a lakóházak pincéiben nyitott pinceborozó. Úgy tûnik, ma ez helyettesíti a hajdani híres kertvendéglốket és hangulatos kocsmákat.

\section{A városrész megújulásának fớvárostól is függó nagy kérdései - javaslatok}

A Józsefváros, és ezen belül a Közép-Józsefváros északi része is - mint minden hasonló, Nagy Körútra fũzổdố városrész, a legtermészetesebb módon ezer és ezer szállal kötôdik és kapcsolódik a fỗváros életének minden területéhez.

Mégis a Józsefváros esetében ez a tény talán még nagyobb jelentốségư, részben, mert ez a városrész Budapest közepén, szinte annak geometriai tengelyében helyezkedik el, másrészt a fơváros komoly közüzemei, szociális intézetei, iskolái múköodnek itt, a Keleti-és a Józsefvárosi Pályaudvar közelségérôl nem is beszélve. Végül arról a felelôsségrốl sem szabad megfeledkezni, mellyel a fôváros tartozik egyik leghátrányosabb helyzetû́ területéért. 
Perczel Anna : A Közép-Józsefváros északi területére készülő részletes rendezési terv programja (Detailed plan and program of the Northern part of Central-Josephstadt in Budapest)

Tér és Társadalom 6. évf. 1992/3-4. 89-162. p.

- A fôvvárost is érintố, vagy a fốvárosra tartozó problémák-javaslatok egy része szerkezetiközlekedési-környezetvédelmi természetũ, az Általános Rendezési Terv szintjén is megoldandó, ma még nyitott kérdés.

- A fốvárost érintố feladatok másik köre a fớváros tulajdonosi szerepéból fakad.

- Néhány olyan kérdésre is szeretnénk felhívni a fôváros figyelmét, ami a fớváros többi kerületét is érintố, de ebben a kerületben is jelentkezõ probléma.

- Végül a legnehezebb kérdés a fớváros szerepe a városrész belsố rehabilitációjában, lakóházainak, lakásainak, környezetének megújulásában, az elviselhetô és elfogadható városi élet kialakításában.

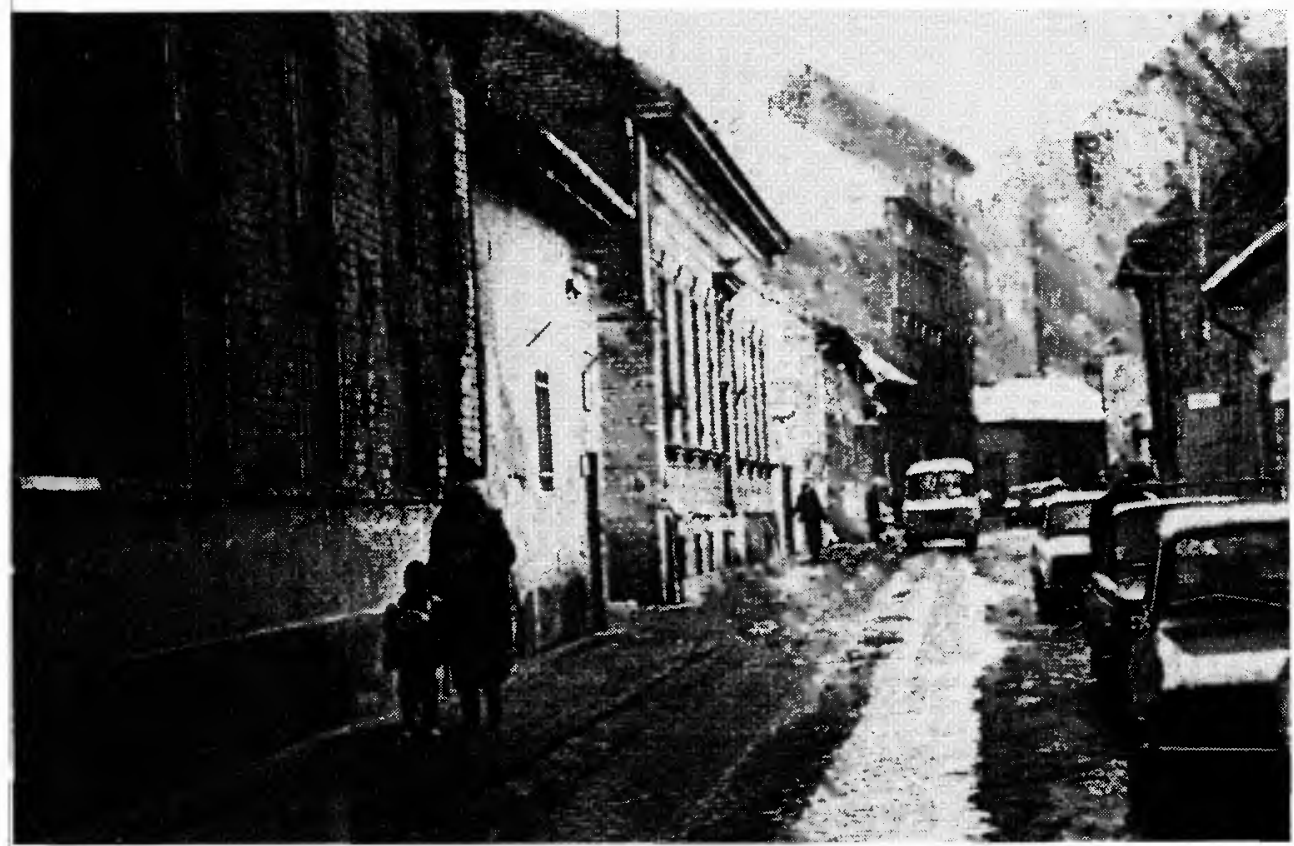

Fơvárosi városszerkezeti-közlekedési problémák és összefüggések. A javitás lehetóségei józsefuárosi nézốpontból

\section{E fejezet szerzóje Miklóssy Endre}

\section{A Józsefvárosi Pályaudvar}

A város második ,,indóháza" volt (1858), és bár a késổbbi fejlódés periférikussá változtatta, kiváló vasút-szerkezeti adottságai a mai napig megmaradtak. A városszerkezeti adottságok - ettól eltéróen - elég kedvezốtlenek ugyan, de a fejlesztésnek a fô célja éppen ezen adottságoknak az alapvetố megjavítása.

Tervezési területünknek - a külsô Józsefvárosnak - ugyanis a meghatározó fontosságú pontfa ez a pályaudvar. 


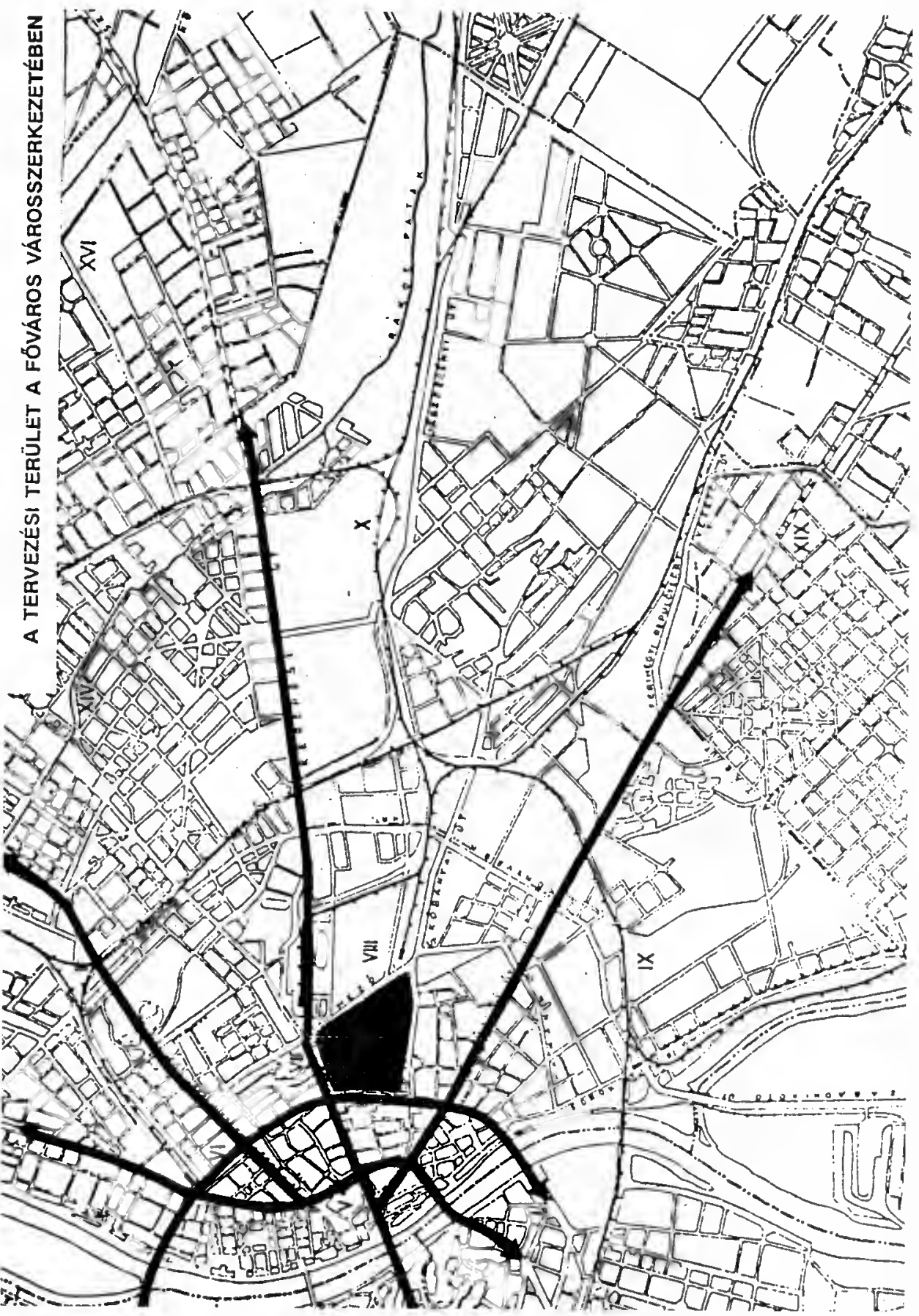




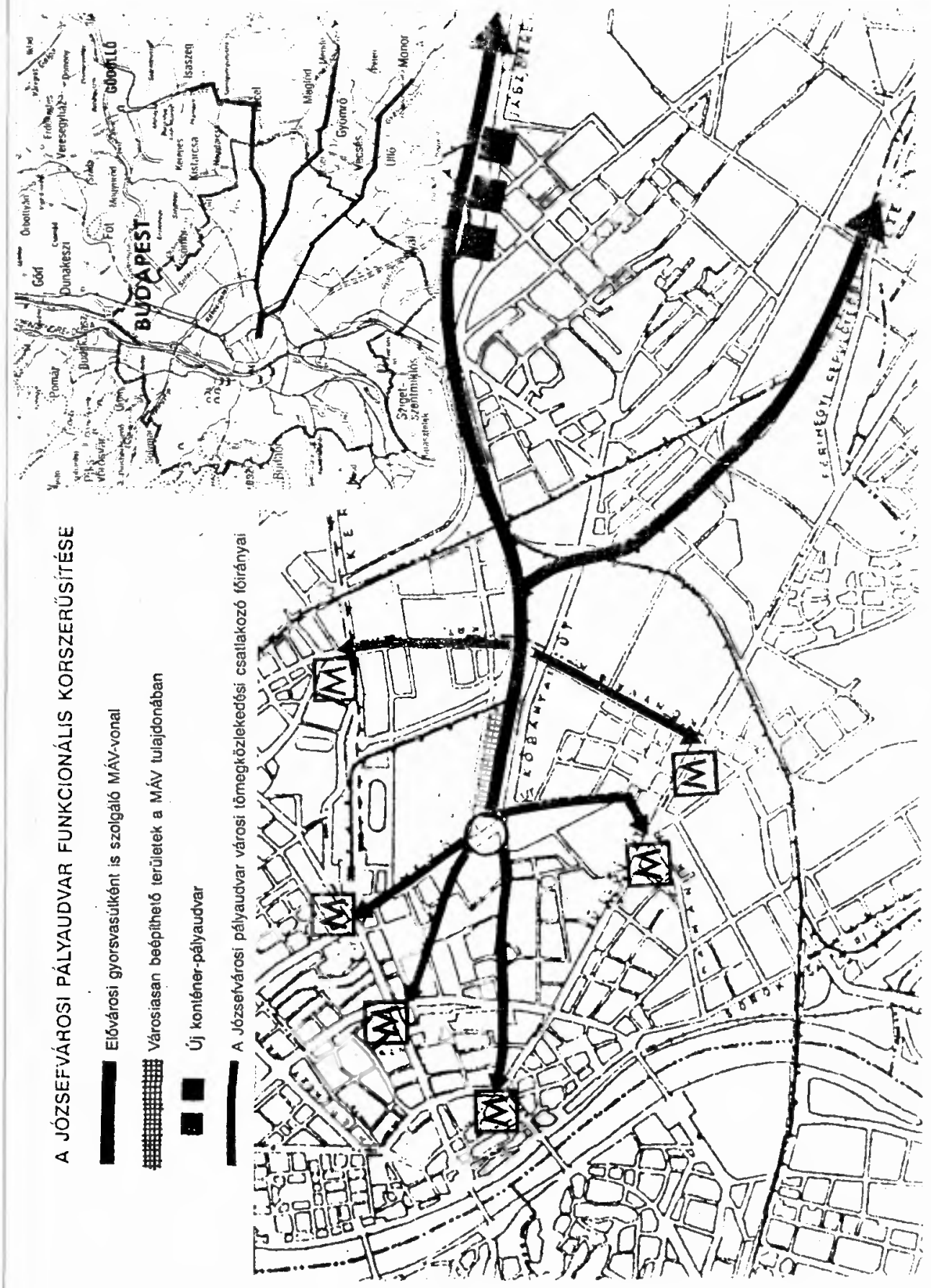


Perczel Anna : A Közép-Józsefváros északi területére készülő részletes rendezési terv programja

(Detailed plan and program of the Northern part of Central-Josephstadt in Budapest)

Tér és Társadalom 6. évf. 1992/3-4. 89-162. p.

120 Perczel Anna

TÉT 1992 • 3-4

— vasútüzemi szempontból a Keleti bốvítése drága és nehézkes, jóval egyszerứbb a távolsági forgalom egy részének az ideterelése;

- a pályaudvar alkalmas arra, hogy a legkedvezóbb fogadója legyen az elóvárosivá átalakuló vasúti forgalomnak. Elsôsorban a Gyömrố-Nagykáta vonal jön itt számításba, amelynek a fôvároson belüli jelentósége sem csekély, ugyanis a legkedvezôbb és legolcsóbb megoldása a rákosi (XVIII. kerületi) tömegközlekedésnek;

- ez a funkcionális felértékelôdés pedig hallatlanul fontossá teszi az egész kapcsolódó területet - az Orczy tér például néhány éven belül a fôváros egyik legfrekventáltabb pontja lesz. Annál inkább így van ez, mivel a terület mai beépítési viszonyai - eltérôen olyan jelenlegi forgalmi centrumoktól, mint pl. a Baross tér, meglehetôsen elavultak. Vagyis sok lehetôséget kínálnak az átépítésre, és az ezáltal bekövetkezố ingatlan-felértékelôdésre is.

Magát a pályaudvart a következôk szerint célszerư korszerúsíteni:

- Meg kell szüntetni a konténer-pályaudvart. Ez a fôváros kellős közepén egyébként sincs szerencsés helyen. Ki lehet telepíteni valamelyik jó közúti kapcsolattal rendelkezổ rendezô pályaudvarra, talán valamelyik rákosira.

$\mathrm{Az}$ így elóálló terület - kedvezổ beépítés esetén - a vasút számára is komoly értéket jelenthet;

- Az elổárosi forgalom számára állomást kell kialakítani a Hungária körúti, nagy tömegközlekedési jelentôségư, kiépülő́ csatlakozáshoz;

- Magát a pályaudvari épületet célszerủ mủemlékként kezelni, és a forgalomátalakulás és korszerũsítés számára ehhez illeszkedố megoldásokat találni.

Az Orczy tér

Értékelhetố közterekben Budapest hallatlanul szegény, és ettól nem tér el az Orczy tér sem, ami nem egyéb valamiféle útkeresztezôdésnél. Forgalmi szerepe azonban nem csekély, és további, szinte beláthatatlan funkció-növekedés elôtt áll. Mivel eme funkciók nagyrészt a Józsefvárosi Pályaudvarral kapcsolatban alakulnak ki, jó ha a tér ezt építészetileg is értelmezni tudja.

Megítélésünk szerint a pályaudvar ma már patinás fỏépülete, az elốtte fekvốtágas, funkcionálisan és esztétikailag is igen jól felhasználható teresedéssel igen jó kiinduló alap lehet mindehhez.

Az elvi tér-konstrukció azonban itt elég bonyolult - eme , névtelen" térhez kapcsolódik egyik oldalról maga az Orczy tér, a mögöttes Kálvária és Golgota terekkel, másik oldalon pedig a Teleki tér, a maga térbốvületeivel.

Ez az együttes - amelynek, még egyszer hangsúlyozni kell, igen nagy a jövớbeni funkcionális szerepe - egyúttal óriási potenciális urbanisztikai értéket is jelent. Célszerũ volna ennek a feltárására városépítési tervpályázat kiírása, amely kellô menedzselés esetén, a konjunkturális érdeklôdésére is kedvezô hatással volna.

Az ügy kritikus, , kardinális pontja” a villamosremiz, amivel ezért érdemes külön is foglalkozni.

\section{A villamos remiz}

Jelenlegi helyén komoly akadálya minden érdemi fejlesztésnek. Lehetôség van viszont a remiz áthelyezésére egy kevésbé értékes területre, és ezáltal a jelenlegi telek felszabadítására jóval értékesebb és hasznot hajtóbb funkciók elhelyezése céljából. 
Perczel Anna : A Közép-Józsefváros északi területére készülő részletes rendezési terv programja

(Detailed plan and program of the Northern part of Central-Josephstadt in Budapest)

Tér és Társadalom 6. évf. 1992/3-4. 89-162. p.

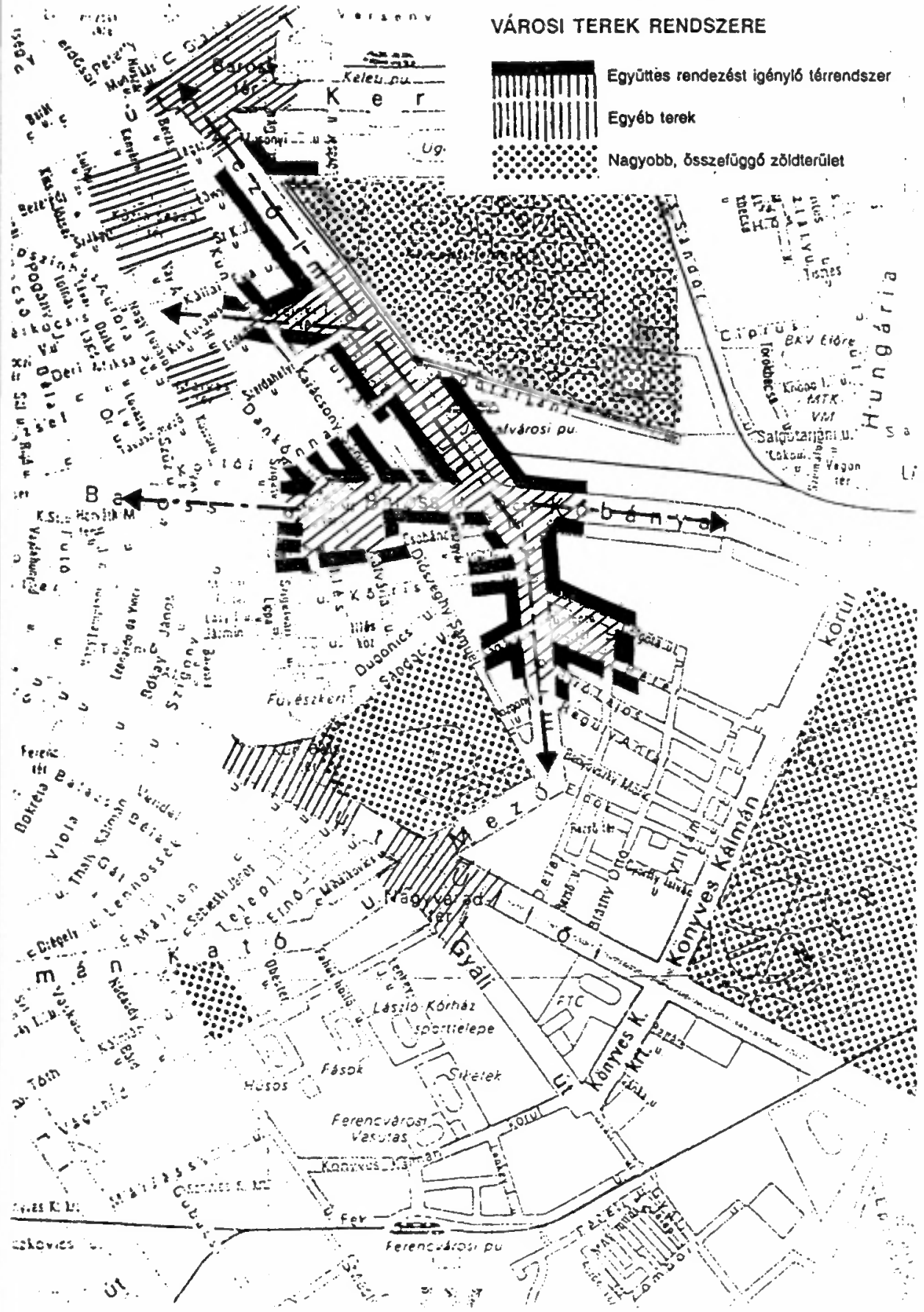


Perczel Anna : A Közép-Józsefváros északi területére készülő részletes rendezési terv programja

(Detailed plan and program of the Northern part of Central-Josephstadt in Budapest)

Tér és Társadalom 6. évf. 1992/3-4. 89-162. p.

\section{A ,városárok-körút" kialakításáról}

Ez a Fiumei út-Orczy út-Haller út - egykori városárok vonalban alakult ki, elemeiben létezô, de egészében sem közlekedésileg, sem városépítészetileg nem eléggé kihasznált lehetốség. Mivel azonban nagyrészt kiépült, viszonylag olcsón, egyszerúen kifejleszthetổ - és a külsố Józsefváros számára valósággal létfontosságú - szerkezeti elem.

A Világkiállítással is kapcsolatban van, ugyanis a legkézenfekvốbb összeköttetés az EXPOterület és a Keleti Pályaudvar között. Ezért a kiépülése a következõ évek során mindenképpen várható. Azzal a fejlesztô hatással együtt, amit a tervezési területünkre és az imént leírt kulcsfontosságú területekre (mindenekelốtt az Orczy téri tér-rendszerre) gyakorol majd.

Szükséges, de jelen munka keretében nem egészen tisztázható, e körút összefüggésrendszere. Részben a déli szakaszon (Ferencváros és Buda felé), részben pedig az északin (a Teréz- és Erzsébetváros felé). Itt a kapcsolati elemek mintha adottak lennének. A Rottenbiller utca és a Baross téri felüljáró ebbốl a szempontból igen fontosak, de komoly forgalmi és szociális vizsgálatok kellenek ezek optimális kialakításához.

Ez a helyzet a Baross térrel is, amirốl egyértelmũen kiderül, hogy jelenlegi formája nem kedvezô, de korszerũsitése komoly tervezési feladat. Annyi azonban világos, hogy eme új , ,körút" tömegközlekedésének a kulcsa a korszerüsített villamos, és ennek a villamosnak közvetlen forgalmi kapcsolatban kell állnia a Mosoni utcán keresztül a Thököly úti villamosjáratokkal. Külön vizsgálatot igényel az a kérdés, hogy mekkora a forgalom, és miképpen menjen a Rottenbiller utcán át az Erzsébetvárosba.

\section{A Rákóczi út forgalma}

A jelenlegi kedvezôtlen helyzet egy hajdani elhibázott koncepció eredménye. Ez a koncepció a Rákóczi út autósztrádává való átalakításával akarta itt keresztülvezetni lényegében az egész ország kelet-nyugati forgalmát. Felhasználta ehhez a Rákóczi út alatt épülổ tömegközlekedési fổvonalat, a kelet-nyugati METRO-t, és erre hivatkozással 40\%-kal megnövelte a közúti forgalmi kapacitást, mégpedig a villamosforgalom megszüntetésével, és a helyenkénti árkádosítással. (A további kapacitásnöveléshez már háztömbök és utcasorok lebontása lett volna szükséges, ezért nem került rá sor.)

A METRO viszont - többféle okból - mégsem elég a tömegközlekedés lebonyolítására, ezért ki kellett alakítani a Rákóczi úton a 7-es autóbusz-rendszert is, amelynek a szállítási kapacitása vetélkedik a METRO-éval. E buszok ugyanakkor hatalmas forgalmat vonzanak erre a területre, és igen komoly környezetterhelést és szennyezést jelentenek. (A megoldáshozjavasolt újabb METRO-vonal a Rákóczi út alatt nyilvánvalóan csak a jelenleg buszok által lekötött forgalmi kapacitást szabadítaná föl más gépjármûvek számára.

A Rákóczi út jelenlegi forgalmát a város, vagy az érintett városrészek szempontjából élesen kétfelé lehet választani.

- Alapvetốen káros minden átmenô forgalom. Legyen az országos és nemzetközi, vagy pedig a fôváros kerületrészei közötti. A tranzitforgalom megszünése nem várható mástól, mint a városmenti körgyưrũ megépülésétốl, ami lehetổvé teszi e forgalom más irányba történố elterelését. A fövárosi kerületrészek közötti forgalom átalakítása pedig komplex városfejlesztési probléma. Nézetünk szerint két meghatározó eleme van: 
Perczel Anna : A Közép-Józsefváros északi területére készülő részletes rendezési terv programja

(Detailed plan and program of the Northern part of Central-Josephstadt in Budapest)

Tér és Társadalom 6. évf. 1992/3-4. 89-162. p.

A RÁKÓCZI ÚT ÁTFUNKCIONÁLÁSA
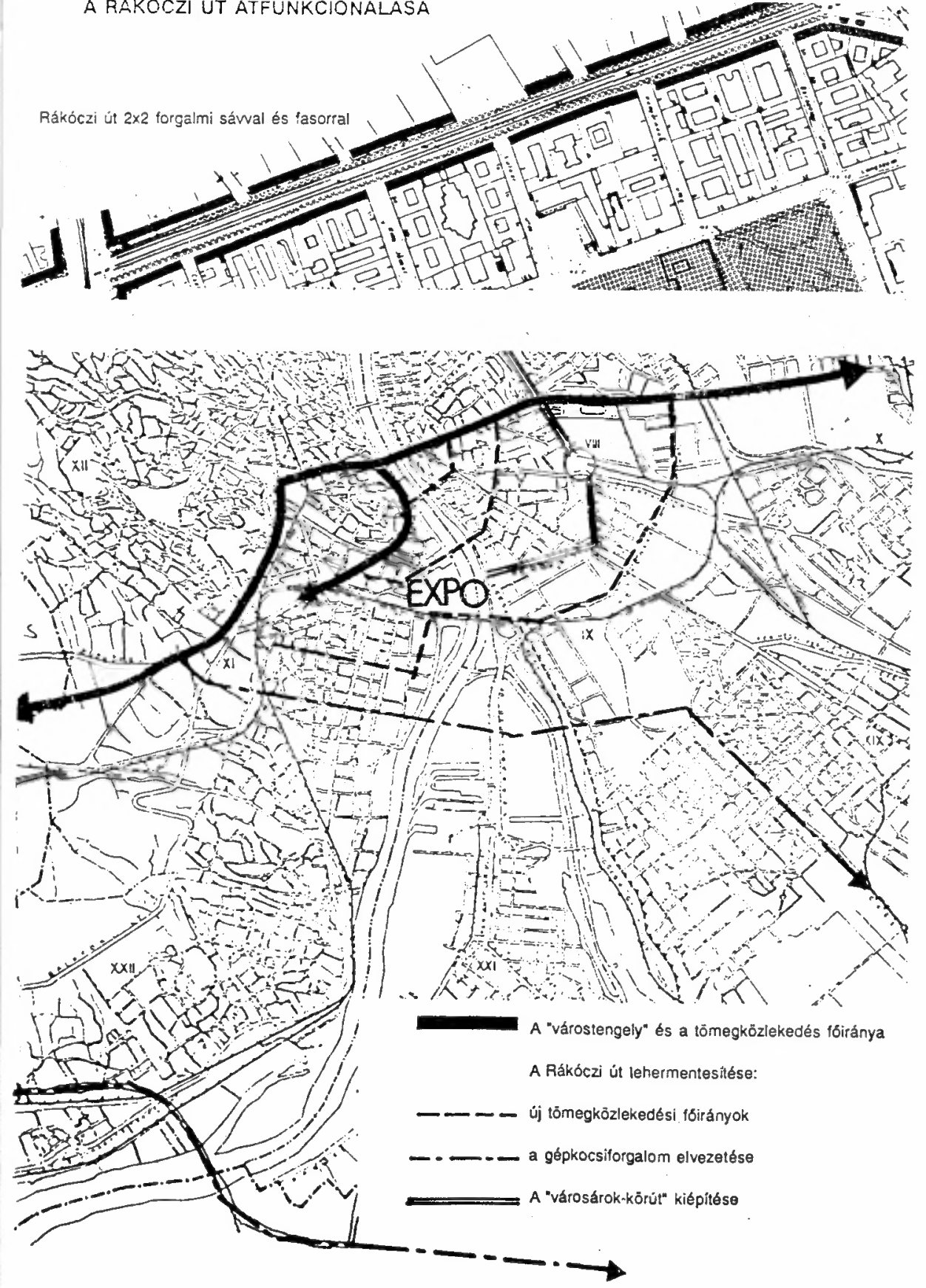
Perczel Anna : A Közép-Józsefváros északi területére készülő részletes rendezési terv programja

(Detailed plan and program of the Northern part of Central-Josephstadt in Budapest)

Tér és Társadalom 6. évf. 1992/3-4. 89-162. p.

*az egyik, hogy a teherforgalom, amelynek célja a város belsổ része - legyen az akár ipari forgalom, akár raktározási, akár pedig a városi kereskedelem ellátására szolgáló - csakis kivuullról, a várost feltáró gyưrữ-elemekrốl legyen lebonyolítható;

*a másik a belsố városrészben lakók személyi forgalma is lehetốleg inkább más irányba terelốdjék.

Nagyon kedvezốtlen ebból a szempontból az a kiépült ,,országtengely”, ami a Kerepesi útRákóczi út-Erzsébet híd-Hegyalja út-Budaôrsi út nyomvonalán át vezet.

Ez ugyanis egy óriási kapacitású, tehát igen nagy forgalmat vonzó közlekedési tengely. Forgalmát csakis úgy lehet csökkenteni, ha

- csökkentjük a kapacitást (a közlekedési sávokat); és

- más irányba vezetố kapacitásokat teremtünk.

Itt ismét a gyưrư irányú útkapacitások bớvítése a megoldás.

- Alapvetốen hasznos az a városi forgalom, ami ebbe a térségbe irányul. A Rákóczi út városi funkciója ma is igen jelentôs, egyfajta , Avenue des Shamps-Élysées"'vé alakítható, ha urbanisztikai környezete megjavítható. A javítás módozatai a következốk lehetnek:

*olyan városi tömegközlekedés kialakítása, ami nem az átmenố forgalmat szolgálja, hanem fốképp az itteni városrészek kapcsolatát;

*a gyalogosforgalom feltételeinek az általános javítása;

(Ebbe egyrészt a járdaszélesség bớvítése tartozik, másrészt pedig a városi környezet, a bérházföldszintek passzázs-rendszerũ átalakítása.)

"az általános városi környezet javítása.

A Rákóczi út kibốvítésének annyi haszna legalábbis van, hogy igen barátságos fasor telepíthetô ide, persze csak ha a forgalmat sikerül jelentổsebb mértékben máshová irányítani.

Hogy ez az átalakítás mennyire növelné a kereskedelmi és egyéb itteni funkciókértékét, hogy az abból származó bevételeket és bérleti jövedelmeket miképpen szorozhatná, azt még felmérni sem lehet.

A 7-es autóbusz kiváltása-helyettesítése a forgalom alábbi átrendezésével valósítható meg:

*a Dél-Buda felé menố forgalommal kiépülố körút-rendszerre terelése; (A meglévổ Kis- és Nagykörút mellett ide tartozik a - megerốsített - ,,Városárok-körút" "Fiumei út-Orczy út-Haller út”, és a kilépô, nagy hatékonyságú tömegközlekedéssel rendelkezó Hungária körút.)

*A hegyvidék és Ốrsöd trolibusz kapcsolatának a kiépítése a Hegyalja úton és az Erzsébet hídon keresztül.

\section{A Baross utca forgalmi viszonyainak javitása}

Az utca jelenleg hallatlanul túlterhelt. Ez két komoly hátránnyal jár:

- igen lelassul a forgalom, ami fóképpen a tömegközlekedés minốségi paramétereit (menetsebesség) rontja. A tervezési terület és az ezen városrészre kidolgozott fejlesztési koncepció szempontjából ez igen kedvezớtlen, mert a közlekedés egyik fổ irányban, a Belváros felé vezetố útvonalon, jelent akadályt;

- az irdatlan forgalom a nem hozzá méretezett keskeny utca funkcionális felhasználásának a lehetốségeit is csökkenti. 


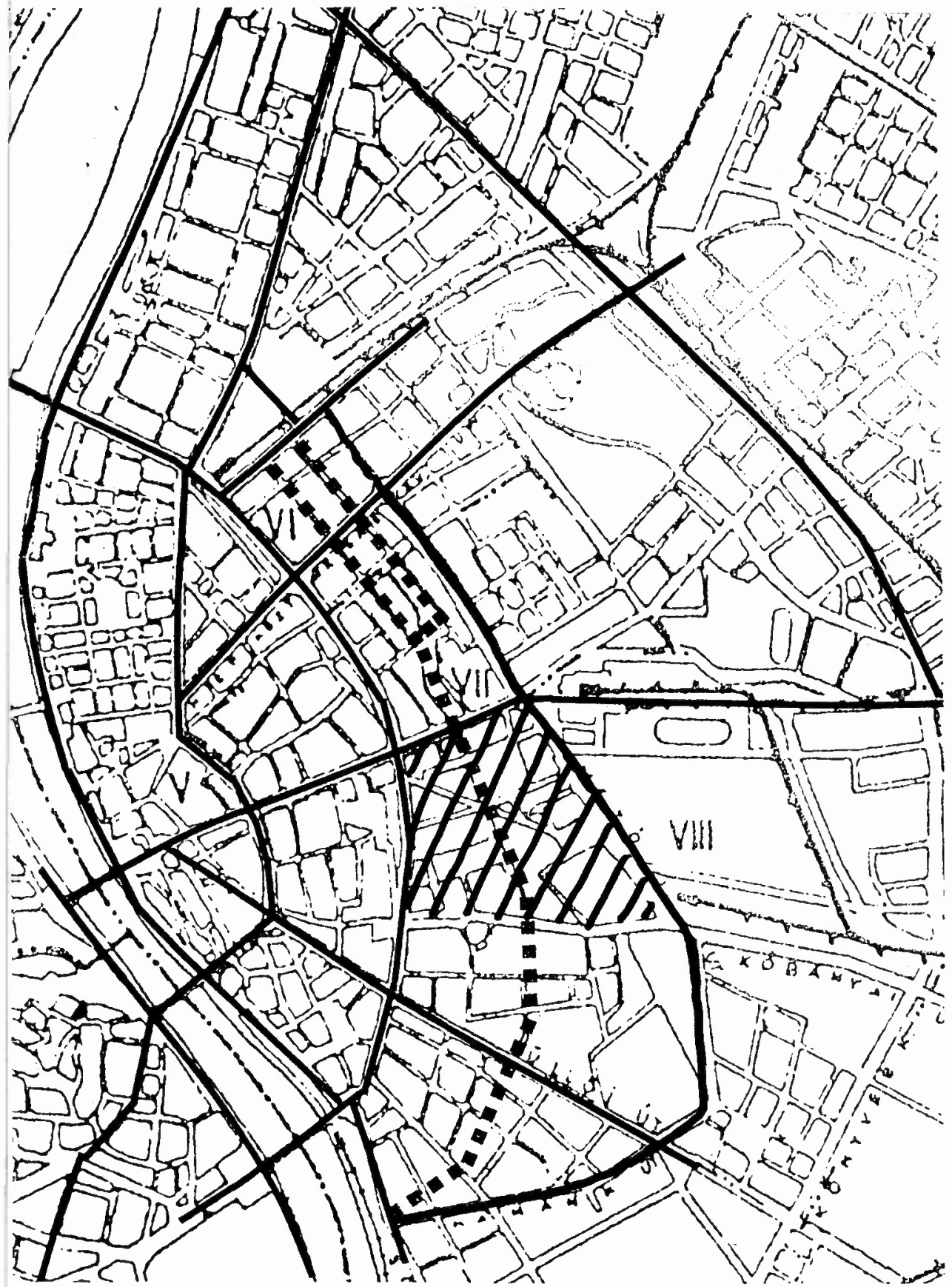

- - A ,rekonstrukciós körút" tervezett vonala 
Perczel Anna : A Közép-Józsefváros északi területére készülő részletes rendezési terv programja

(Detailed plan and program of the Northern part of Central-Josephstadt in Budapest)

Tér és Társadalom 6. évf. 1992/3-4. 89-162. p.

126 Perczel Anna

TÉT 1992-3-4

A gépkocsiforgalom Baross utcai csökkenése lehetôvé tenné, hogy a környezetbarát trolibusz-közlekedés minôsége jelentớs mértékben javuljon ezen a fontos kerületi útvonalon. Ez azonban az utca funkcionális szerepét is felértékelné: ily módon a városi élet valóságos tengelyévé alakulhatna át, javulna az üzlethelyiségek-irodák felhasználhatósága, piaci értéke, amit a bérleti díjakon is le lehet mérni.

Ezen a közvetlenül kínálkozó hasznon túlmenôen a Baross utca ilyetén felértékelốdése döntố befolyással lehet az egész Józsefváros rekonstrukciójára is.

A ,,rekonstrukciós körútról”

Régi gondolat ez, és évtizedek óta helyet kap a fớváros mindenkori rendezési terveiben anélkül, hogy tényleges megvalósítása érdekében túl sok történt volna.

A Nyugati Pályaudvar falánál kezdốdne, átmenne a Teréz- és Erzsébetváros közepén, érintené a Köztársaság teret, majd egy sor lakótömb elbontása után átvezetne a Közép Ferencvárosba, s végződne egy másik pályaudvari fal, a Dunaparti Teherpályaudvaré elốtt, a Soroksári útnál.

A koncepció megvalósítása hallatlanul drága volna - nyilván ezért nem is kezdtek érdemben hozzá (csak a Práter utcai bulldózeres lakótelepen épült meg egy szakasza), városszerkezetileg pedig rendkívül értelmetlen, mivel sehonnan-sehová nem vezet. Igazából nem tudni, mi célt is szolgálna. Egyes föltevések szerint azért kell, hogy ha egyszer a fốcsatorna felújítása miatt le kell majd zárni a Nagykörútat, akkor annak a forgalmát ide lehessen terelni. Ez azonban így értelmetlenség. Valószínúbb, hogy a kétségkívül túlzsúfolt ,,spekulációs bérház övezet” fellazítására szánhatták. De ez az elgondolás nem jó. Funkciótlan, és városszerkezetileg értelmezhetetlen holtsávot jelentene (amellett, hogy létrehozásához a szükséges anyagi erôforrásokat belátható idổn belül nem lehet elốteremteni).

Vitán fölül áll viszont e koncepció két alapeleme:

- a bérház-övezet fellazításának szükségessége; és

- egy közbensố, a Nagykörút és Hungária körút közötti körút kedvezổ volta.

Jelen tervünkben, amely a Külsô-Józsefvárosra készült, más úton kerestük a két alapprobléma megoldását:

- a , ,ellazítást" a terek és térrendszerek új építészeti koncepciójával, az utak tehermentesítésével, és a zöldfelületek lehetổ legnagyobb mértékũ kiterjesztésével kívánjuk megoldani;

—új körúttá pedig a volt ,,Városárok vonalában fekvổ útrendszert akarjuk fejleszteni (Rottenbiller utca-Fiumei út-Orczy út-Haller út).

Koncepciónk e kérdésköröket részletesen is kifejti.

A rekonstrukciós körutat azonban, mivel szabályozási korlátaival nehezíti a városrész rehabilitációját, tönkreteszi kialakult szerkezetét, törölni kell a város Általános Rendezési Tervébó́l.

\section{A fớváros különleges felelössége}

Ennek a városrésznek, mint azt a bevezetốben már jeleztük, a fớvárosban egyedülálló módon súlyos helyzettel kell szembenéznie, hiszen mindazt ami a modern nagyvárosok hagyományos és új, de mindenképpen , kemény" problémáit jelenti, itt egy helyre koncentráltan lehet megtalálni. 
Perczel Anna : A Közép-Józsefváros északi területére készülő részletes rendezési terv programja (Detailed plan and program of the Northern part of Central-Josephstadt in Budapest) Tér és Társadalom 6. évf. 1992/3-4. 89-162. p.

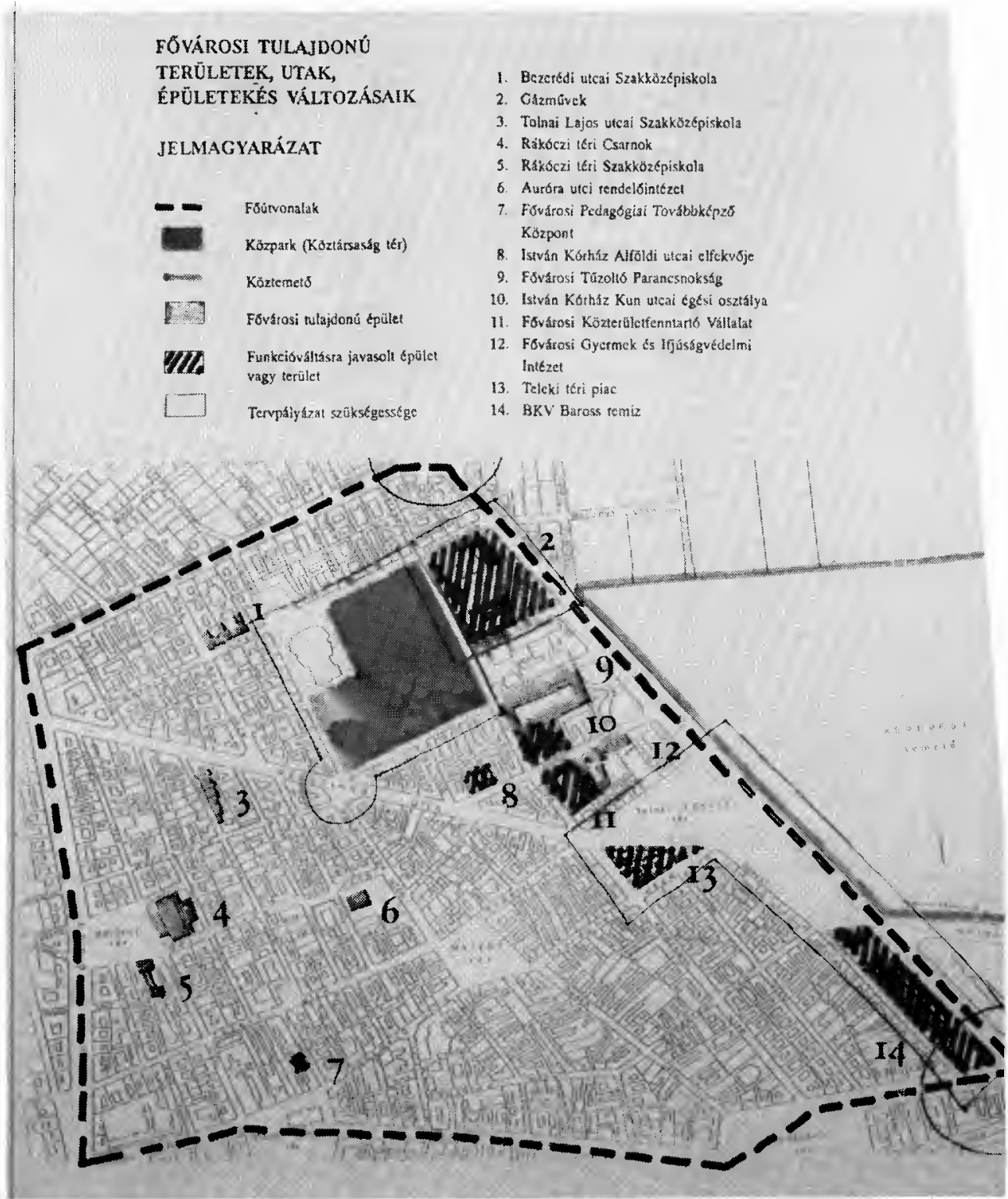


Perczel Anna : A Közép-Józsefváros északi területére készülö részletes rendezési terv programja

(Detailed plan and program of the Northern part of Central-Josephstadt in Budapest)

Tér és Társadalom 6. évf. 1992/3-4. 89-162. p.

$128 \quad$ Perczel Anna

TÉT 1992 -3-4

A társadalmi-történeti-szociológiai vizsgálatok szerint az itt gyülekezổ problémák okai idóben és térben is messzire vezetnek. Az egész ország történelme és jelenlegi helyzete is erốsen befolyásolta és befolyásolja ma is azt, ami itt történik. Egyértelmũ ezért, hogy a feloldással, tehát a valóságos és érzékeny rehabilitációval járó terheket nem lehet csupán a kerületre hárítani. A fốvárosnak feltétlenül vállalnia kell a sokszorosan hátrányos helyzetũ területét, és komolyan meg kell fontolnia, milyen módon és milyen gyorsan tud segíteni? Valószínúleg nincs túl sok idố a gondolkodásra! Hiszen itt, a fôváros közepén, a Nagykörútra fúzốdôen, és a szemünk láttára, a hasonló helyzetũ belsố városrészek leépülését komolyan meghaladó, prostituált negyeddel is terhelt, nagyvárosi gettó van kialakulóban.

A fốvárosnak és a kerületnek akkor kell megtennie a kimozdulást elôsegítô elsố lépéseket, amikor az állam teljesen kivonul a lakásépítésbôl, és minden felelôsségvállalásból is, ami a városokra vonatkozik. Akkor, amikor sem az önkormányzat, sem a városrész lakói nem rendelkeznek fölösleges pénzekkel, nincsenek megfelelố rehabilitációt segítổ törvények, jogi- pénzés adóügyi szabályozások és kedvezmények sem a régi épületek felújítására, sem új lakások építésére. Mégis lépni kell az itt élổ emberek érdekében is, de azért is, mert az itt kialakuló helyzet nem áll meg e városrész határainál, hanem - túllépve rajta - elốször közvetlen környezetére, majd az egész városra is kisugárzik.

A rehabilitáció elốkészítése, megszervezése, gazdasági hátterének kialakítása a kerülettel együtt megoldandó, hosszú, bonyolult folyamat.

Itt néhány olyan gondolatot sorolunk fel, melyekkel a fốváros az elốkészítési folyamatot és a kiinduláshoz szükséges elsố lépéseket segíthetné.

a) Az elókészítési folyamat során - a részletes rendezési terven túl, melyet a kerület készíttet - véleményünk szerint szükség van:

- teljeskörü szociológiai tájékozódásra-vizsgálatra, majd a tervek készítése során - még az elfogadás elốtt - az itt élók szembesítésére a programmal, a részletes rendezési tervvel, és a rehabilitációs elképzelésekkel;

- egy-egy induló project vagy akcióterület alternativ beépítésénél a megfelelố választás, döntés érdekében összehasonlító gazdasági elemzésre;

- a városszerkezetileg legfontosabb, vagy a városképileg legérzékenyebb helyeken tervpályázatok meghirdetésére.

b) A kimozdulás, a rehabilitáció esélyét komolyan befolyásolja az új lakások épitésének lehetôsége a rehabilitációs területen belül, és a rehabilitációs területen kiviul is.

Ebben az esetben a hatékony lakásépítési konstrukciók kialakítása, és a megfelelổ külsổ helykiválasztás és helybiztosítás lenne elengedhetetlenül fontos. Itt komolyan el kellene gondolkozni azon is, nem lehetne-e a századforduló utáni lakásépítési akciókból tanulni? Részben Bárczy István polgármester lakásépítési programjára gondolunk, melynek során a fôvváros összes nehéz helyzetú kerületében hosszúlejáratú külföldi kölcsönökból épültek fel az ún. városi házak, melyek közül ebben a városrészben is található néhány, másrészt olyan szövetkezeti rendszerũ, szintén városi támogatást élvezố lakásépítési akcióra, mint a nem is olyan távoli Tisztviselố telep, vagy a ,Pap-házak" példája.

c) A rehabilitációt segítớáltalánosabb, más kerületekben is jelentkezỏ problémák megoldásához szükséges lenne, hogy a fốváros foglalkozzon: 
Perczel Anna : A Közép-Józsefváros északi területére készülő részletes rendezési terv programja (Detailed plan and program of the Northern part of Central-Josephstadt in Budapest)

Tér és Társadalom 6. évf. 1992/3-4. 89-162. p.

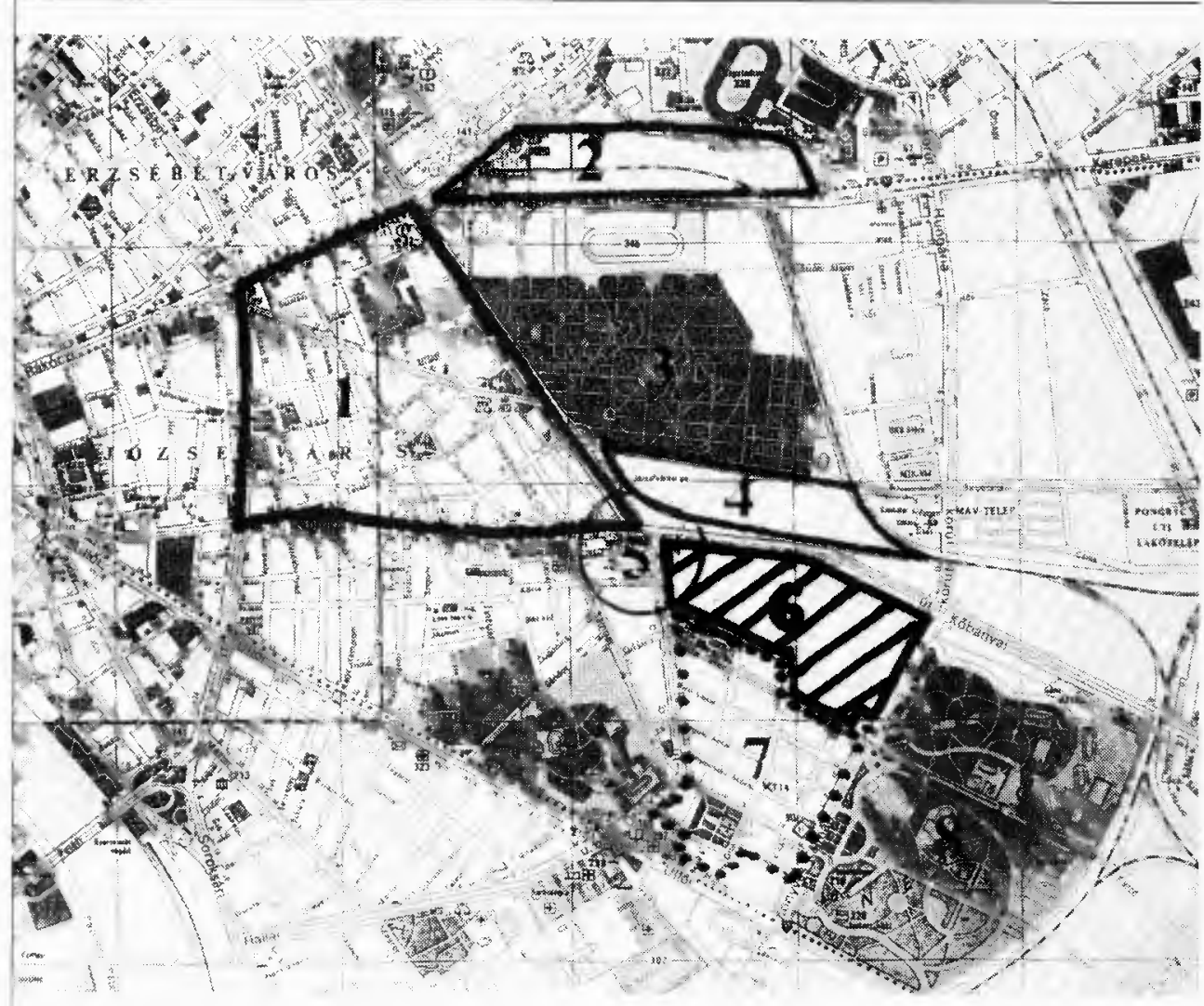

A lakásépités lehetôsége a közelben a Ganz Mávag egy részének felparcellázásával

1. A Közép-Józsefváros északi része

2. Keleti pályaudvar

. Köztemetó

¿. Józsefvárosi pályaudvar
5. Orczy tér

6. Ganz-Mávag területe

7. Tisztviselốtelep

8. Népliget

- A pesti oldalon immár több évtizede tartó folyamatos talajvízszint emelkedéssel, és annak következményeivel.

Részben: korszerú és hatékony szigetelési eljárások kikísérletezésére, másrészt a talajvíz felhasználásának különbözổ lehetốségeire (ipari használat, úttest takarítás, locsolás, autómosás) gondolunk.

- A települési, fóvárosi értékek meghatározásával, számbavételével, és a védelem feltételeinek megteremtésével, mert enélkül esetleges módon alakul és pusztul mindaz, amit óvni, védeni kellene.

Ez azt jelentené, hogy nemcsak a román, a gótika, a barokk és a klasszicizmus, de az eklektika, a szecesszió és a modern építészet kiemelkedổbb beépítéseit, épületeit is számon kellene tertani. Ezen túl védeni a hagyományos városszerkezetet, a városképet, parcellakiosztásokat, ¿. növényzetet, jellegzetes veszélyben lévớ funkciókat, mesterségeket, de hangulati elemeket is. 
Perczel Anna : A Közép-Józsefváros északi területére készülő részletes rendezési terv programja

(Detailed plan and program of the Northern part of Central-Josephstadt in Budapest)

Tér és Társadalom 6. évf. 1992/3-4. 89-162. p.

Addig míg itt Budapesten, és most konkrétan itt ebben a kerületben is, nincs kidolgozva, felmérve és számontartva a települési értékeknek ez a szélesebb köre, mindezen pótolhatatlan értékek veszélyeztetett helyzetben vannak, és egyáltalán nem kizárt teljes vagy részleges megsemmisülésük. Lásd intố példaként Óbuda megsemmisülését!

- A város karakterét jelentó történelmi korszakok nem védett épületeinél átalakítás, tatarozás, rehabilitáció során támasztható elvárások és feltételek meghatározásával. Mindez az igényesség bevezetése lehetne a jelenlegi igénytelenséggel, és elsivárosodással szemben.
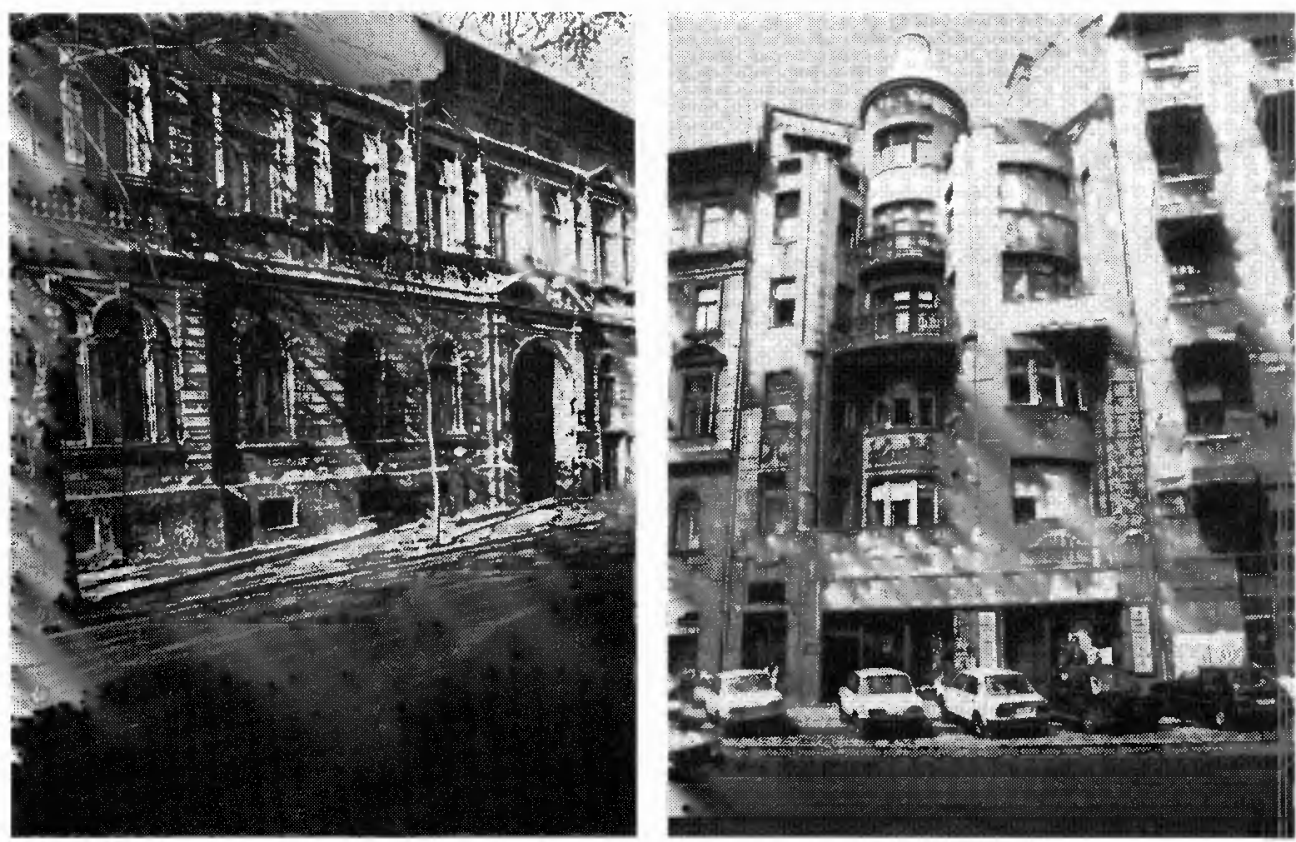

\section{A városnegyed eltéró jellegü területeihez igazodó javaslataink}

A Közép-Józsefváros északi területe három jellegzetesen eltérố, egymáshoz hol határozott különbséggel, hol átmenettel csatlakozó részból áll.

Ez a karakter-különbség éppúgy érzékelhetổ a beépítettség jellegén és minôségén, mint a városrész társadalmi tradícióin, mai társadalmi rétegzổésen, környezeti állapotán, és a mindezt önmagában is jelző lakáshelyzetén. De közintézményeinek, kereskedelmi életének csoportosulásai, vagy hiányai, a városrészt annyira jellemzổ kisiparosság elhelyezkedése, vagy éppen az üres telkek aránya is jelzi ezt a különbséget.

A városi élet minôségét így összességükben és alapvetôen meghatározó, térbelileg is megfogalmazható határok kijelölésével azonban nem akarjuk a városnegyedet szétszabdalni, csak az eltérổ rehabilitációs problémákra és lehetôségekre szeretnénk felhívni a figyelmet. Hiszen jól látható, hogy a területi elkülönülésen belül szigetszerúen találhatók egészen eltérố helyzetư tömbök, utcaszakaszok, és az is, hogy a különbözôség ellenére szerves és igen erôs a kapcsolat, az összefonódás. 
Perczel Anna : A Közép-Józsefváros északi területére készülő részletes rendezési terv programja (Detailed plan and program of the Northern part of Central-Josephstadt in Budapest)

Tér és Társadalom 6. évf. 1992/3-4. 89-162. p.

TÉT 1992:3-4

Városrendezés a Józsefvárosban

131

A Közép-Józsefváros északi részének eltérố jellegũ területei:
A
A nagyvárosias, polgári rész (A jelû terület)

B A nagyváros és a kisváros keveredése (B jelứ terület)
A leszakadó harmadik rész, mely már egyértelmúen külváros, ahol egyszerre van jelen a nagyvárosias, munkásbérkaszárnyák, mellett a kisvárosias és falusias beépítés (C jelú terület)

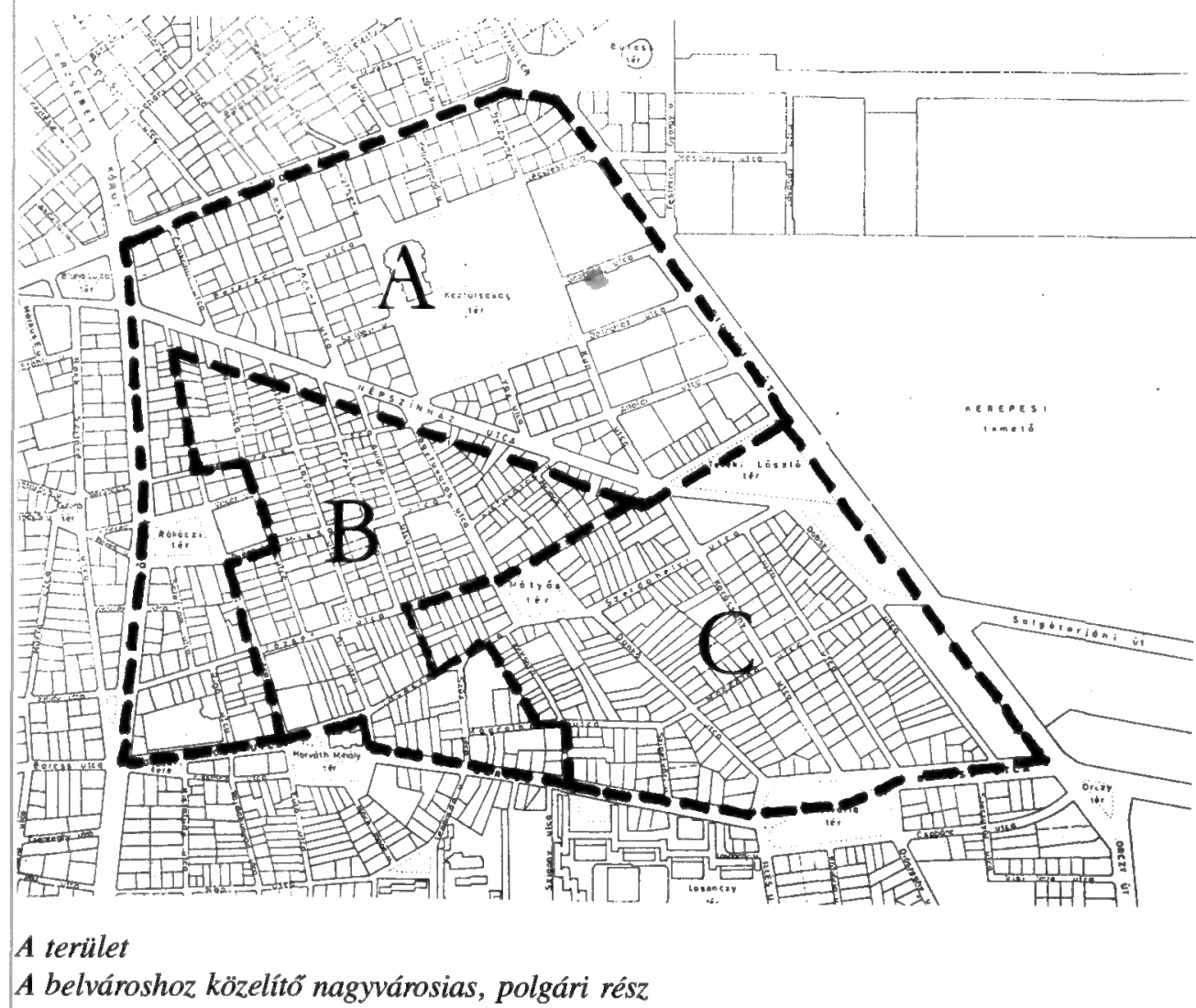

A Rákóczi út és a Népszínház utca közötti terület a Köztársaság tér környékével, a József körút-Rákóczi tér környéke, és a Baross utca kezdeti szakaszát övezổ tömbök területe.

\section{Jellemzôi:}

Ez a polgáriasult fổvárost leginkább képviselố, egységesen, nagyvárosiasan beépült utcák, tömbök területe, részben még a Belsô-Józsefváros folytatása. A területet szinte minden irányból fớútvonalak, és az azokból nyíló terek határolják. Ezeken a városrészt U-alakban keretezó, egységesen beépült részeken, a beépítés döntổen háromemeletes, századvégi vagy századforduló 
Perczel Anna : A Közép-Józsefváros északi területére készülő részletes rendezési terv programja

(Detailed plan and program of the Northern part of Central-Josephstadt in Budapest)

Tér és Társadalom 6. évf. 1992/3-4. 89-162. p.

132 Perczel Anna

TÉT $1992 \cdot 3-4$
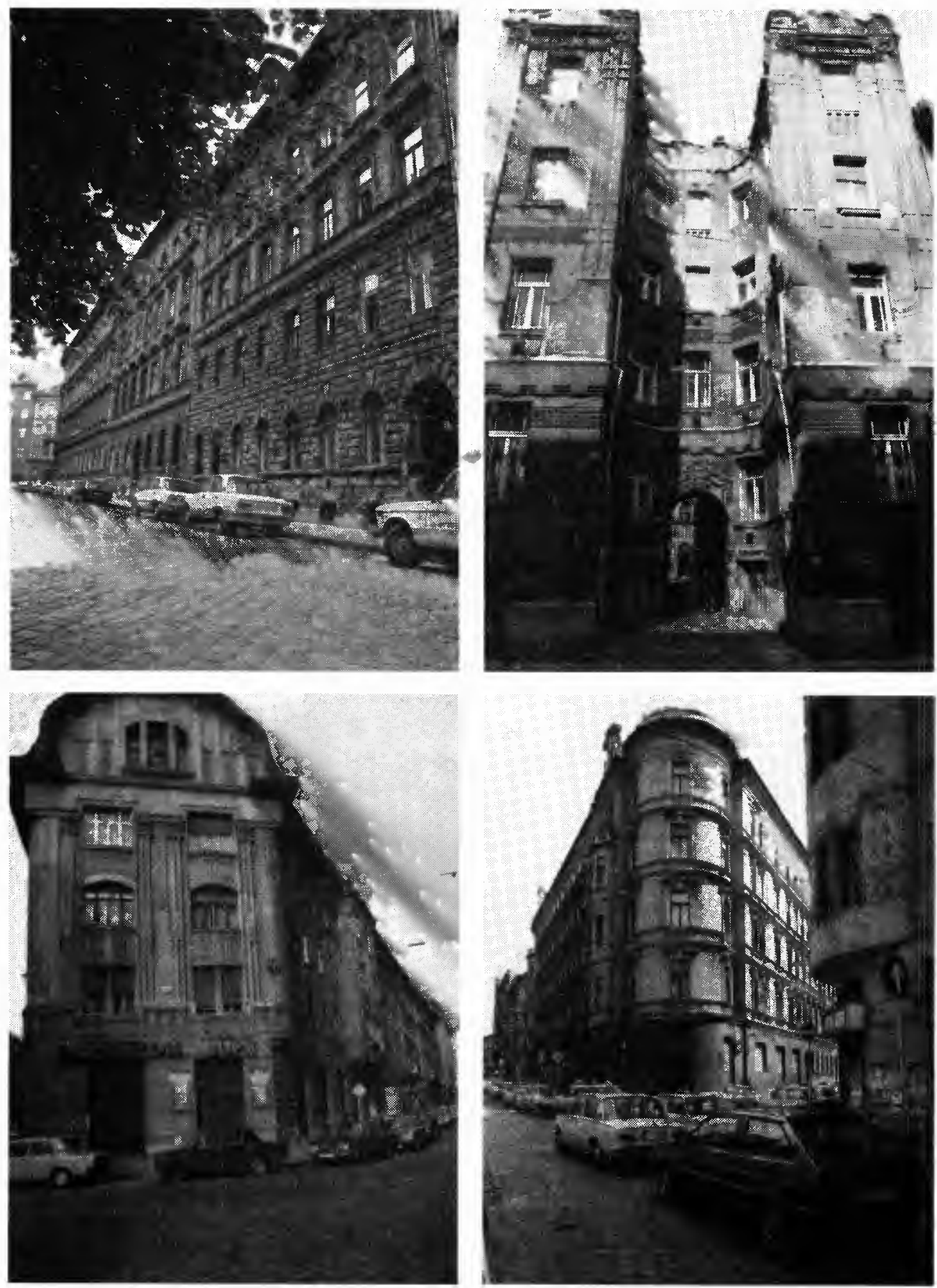

A belvároshoz közelító nagyvárosias polgári rész épületei ...

1. Vay Ádám utca. 2. Népszínház utca-Vay Ádám utca sarok. 3. Magdolna utca 6.

4. Népszínház utca-Tolnai Lajos utca sarok. 
Perczel Anna : A Közép-Józsefváros északi területére készülő részletes rendezési terv programja

(Detailed plan and program of the Northern part of Central-Josephstadt in Budapest)

Tér és Társadalom 6. évf. 1992/3-4. 89-162. p.
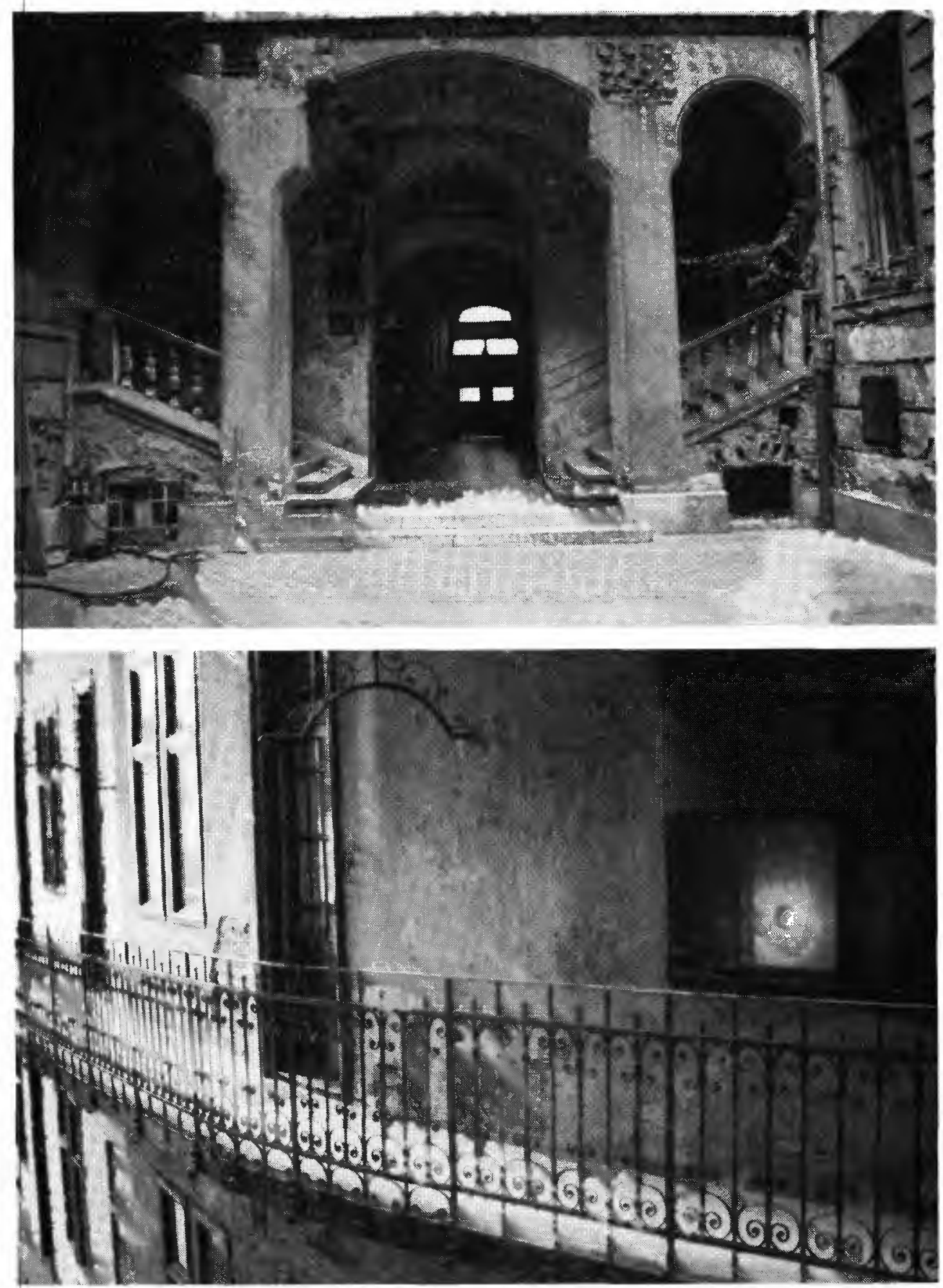

... és belsó terei

1. Salétrom utca 10. 2. Mátyás tér 12. 
Perczel Anna : A Közép-Józsefváros északi területére készülő részletes rendezési terv programja

(Detailed plan and program of the Northern part of Central-Josephstadt in Budapest)

Tér és Társadalom 6. évf. 1992/3-4. 89-162. p.

134 Perczel Anna

TÉT $1992 \cdot 3-4$

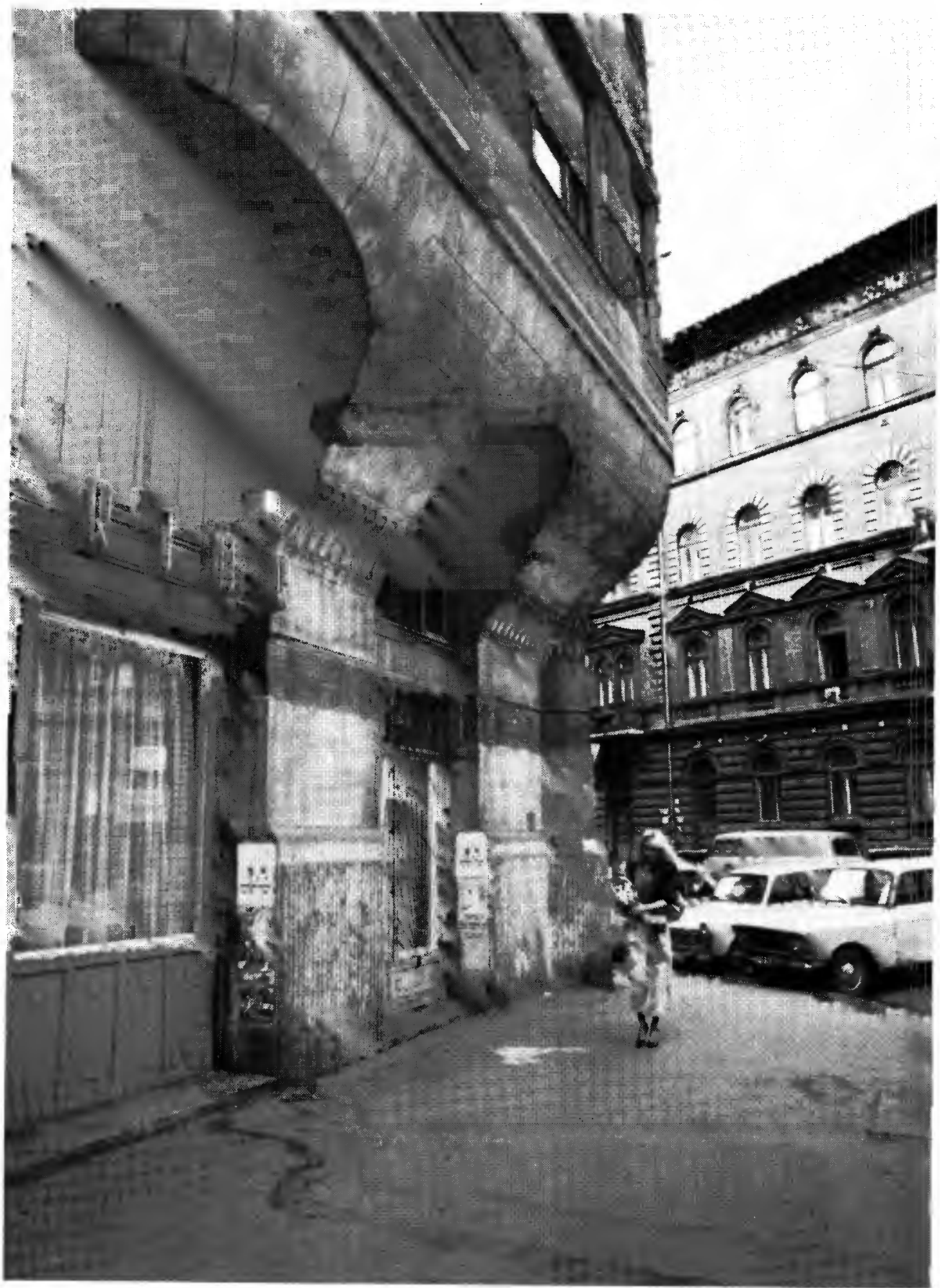

Különleges sarok-teresedés a Népszínház utca-Kiss József utca sarkán 
Perczel Anna : A Közép-Józsefváros északi területére készülő részletes rendezési terv programja (Detailed plan and program of the Northern part of Central-Josephstadt in Budapest)

Tér és Társadalom 6. évf. 1992/3-4. 89-162. p.

után épült, jó minőségú bérházakból áll. A bérházak mellett itt található a felsố- és középfokú intézmények zöme, megfeleló vagy igen jó az ellátás, élénk a kereskedelmi élet, kevés a bontható épület, szinte nincs üres telek.

A lakásviszonyok itt a legkedvezóbbek, a komfortos lakások aránya több mint 75\%, az egyszobás lakások aránya $40 \%$. Jellemzó, hogy a városnegyedben az utóbbi két évben eladott lakások is szinte mind itt találhatók.

Ugyanakkor a beépítettség, a laksúrűség rendkívül intenzív. Kevés a belsố kert, a szabad terület. A fốtvonalak elviselhetetlenül nagy és rosszminôségú forgalma következtében a levegố szennyezettsége és a zaj mértéke sokszorosa a megengedettnek. Ez alól itt csak a Köztársaság-tér környéke kivétel. Az elviselhetetlen légszennyezés mellett a főútvonalak mentên és az azt szegélyezố terek közelében szinte megoldhatatlan gondot jelent a parkolás.

\section{Javaslataink:}

Az egységesen beépült fớtvonalak, utcák, tömbök mentén és azok területén nagyobb beavatkozás nem lehetséges. A hangsúly itt a forgalom lehetséges korlátozásán, a környezet minőségének javításán, és a városrészt övezô fôutak sarokpontjain és teresedések közelében a parkolás kérdésének megoldásán van, mert az egyre súlyosabb környezeti hatások könnyen elindíthatnak kedvezôtlen folyamatokat.

Nagyobb változás csak az itt található, sokszor rosszul használt középületek vagy lakóházak funkcióváltozásától várható.

Ugyanakkor ez az a terület, ahol a kereskedelem a fổutvonalak mentén látható módon húzódik a bérházak udvarai, pincéi felé. Ennek a folyamatnak a további növekedésére számítani lehet és kell is, így komoly földszinti funkcióváltások várhatók, vagy szükségesek (lakás helyett üzlet, vendéglátás, szolgáltatás, üvegezett passzázsok). Szükség lehet még ezen túl is bizonyos arányú, bár kisméretủ, lakásszámcsökkentésre, a rendkívül zárt és levegổ nélküli tömbbelsốk egészségtelen helyzetû̉ lakásainak levegốhöz, fényhez juttatása miatt. A csökkentés azonban igen óvatosan és csak a 25\% körüli komfortnélküli lakások rovására történhet.

Itt található a 6 hektáros összefüggổ zöldterületével különlegesen értéket jelentô Köztársaság tér, mely egyben a fốváros legnagyobb köztéri parkja, és a fớváros életében a jövốben egyre nagyobb szerepet játszó Fiumei út is.

A Fiumei út és Köztársaság tér közötti terület - melyet a város eredetileg a fổvárosi közüzemek használatára szánt és használ ma is - a város bekövetkezett fejlôdése miatt - komolyan felértékelốdik.

Ezért az értékéhez képest rosszul használt területek egy részénél más típusú területhasználatot, funkcióváltást, vagy funkcióváltással egybekötött új, nagyvonalú beépítést javasolunk. A rosszul, vagy városképileg is zavaróan használt területek legnagyobb része fóvárosi tulajdonú. (Fớvárosi Gázmüvek, Fóvárosi Köztisztasági Hivatal, Baross Remíz stb .)

\section{$B$ terület}

A nagyváros és a kisváros keveredése

A Német utca és Bacsó Béla utca-Népszínház utca-Erdélyi utca-Mátyás tér-Koszorú utca-Baross utca által határolt belsỗ városrész 
Perczel Anna : A Közép-Józsefváros északi területére készülő részletes rendezési terv programja

(Detailed plan and program of the Northern part of Central-Josephstadt in Budapest)

Tér és Társadalom 6. évf. 1992/3-4. 89-162. p.
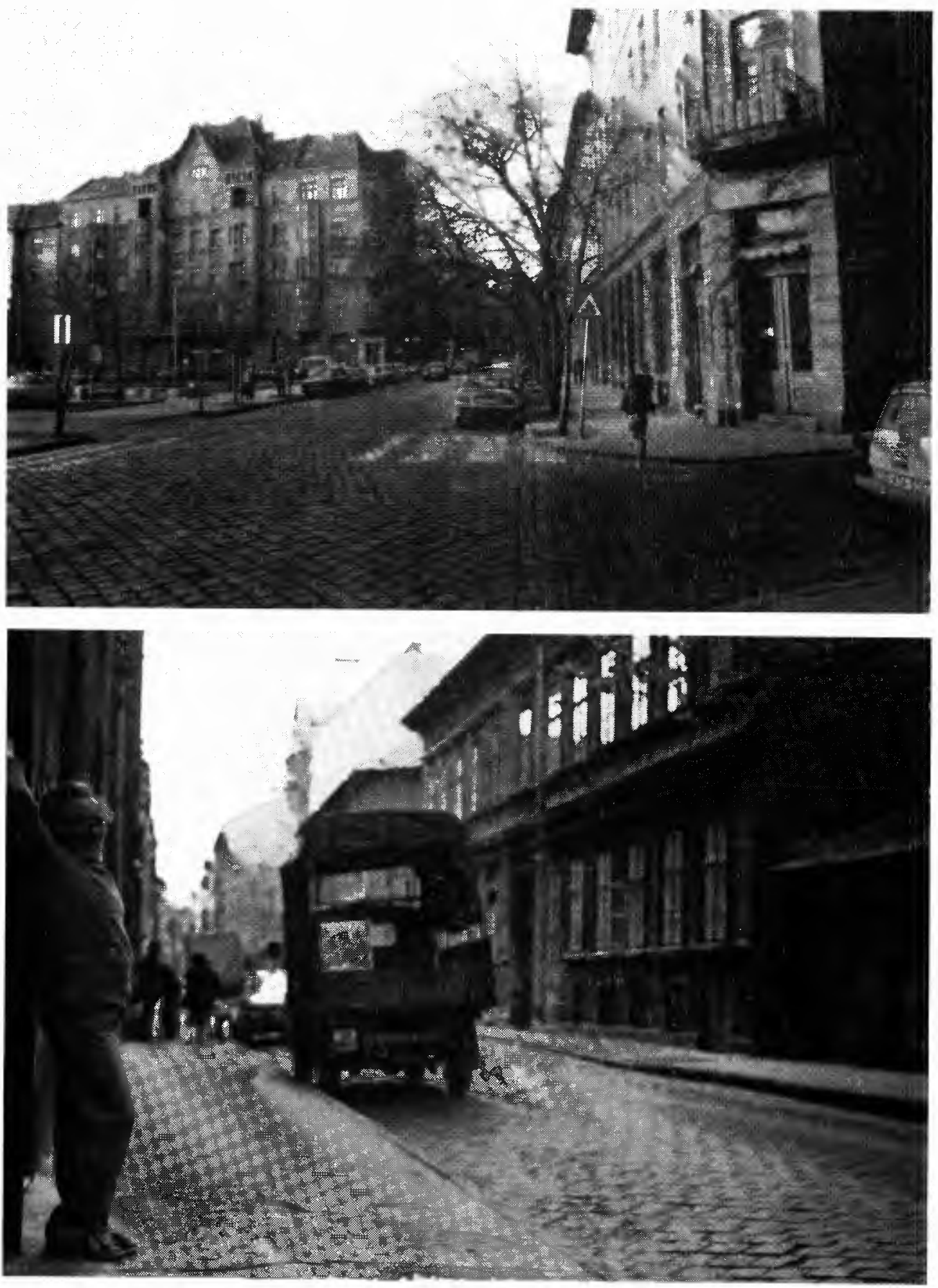

A nagyváros és a kisváros keveredése a városrész középsơ részén.

1. Az Auróra utcai rendeló mellett megbontott Nagyfuvaros utca. 2. A Bérkocsis utca. 
Perczel Anna : A Közép-Józsefváros északi területére készülö részletes rendezési terv programja (Detailed plan and program of the Northern part of Central-Josephstadt in Budapest) Tér és Társadalom 6. évf. 1992/3-4. 89-162. p.
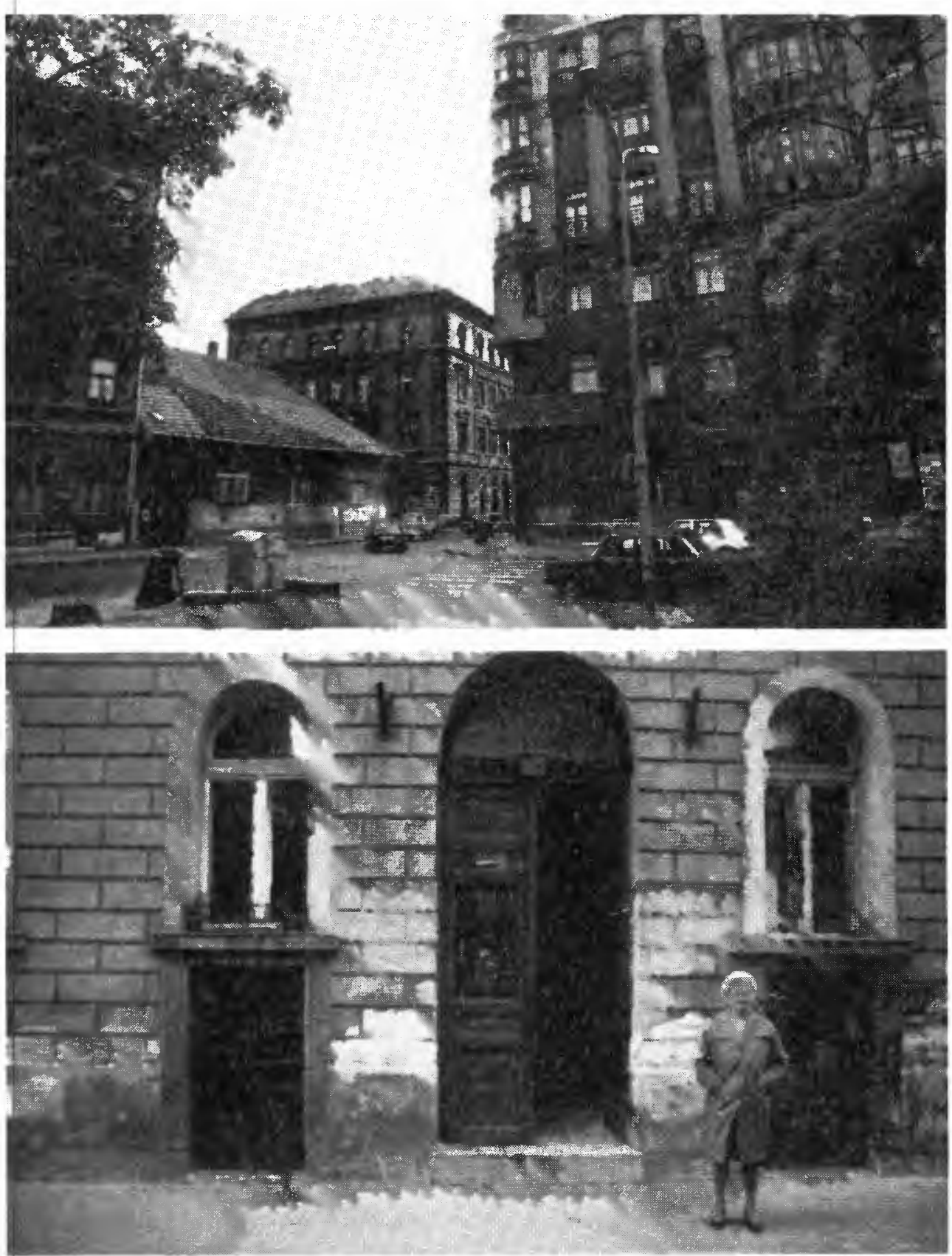

A nagyváros és a kisváros keveredése a város középsố részén

1. A Mátyás tér egyik sarka, ahol egyszerre van jelen egy-egy értékes épülettel a városrészt jellemzố három korszak. 2. Tipikus eklektikus bérház-részlet a szerényebbek közül (Kisfuvaros utca 4.). 
Perczel Anna : A Közép-Józsefváros északi területére készülő részletes rendezési terv programja

(Detailed plan and program of the Northern part of Central-Josephstadt in Budapest)

Tér és Társadalom 6. évf. 1992/3-4. 89-162. p.

$138 \quad$ Perczel Anna

TÉT 1992-3-4

\section{Jellemzói:}

Ez a városnegyed közepe. Szúk utcák hálózata közé zárt, keskeny, párhuzamos tömbök jellemzik a terület nagyobb részét, sokszor igen kisméretũ, keskeny telekosztással. Ezekben a szứk utcákban általában a múlt század közepéról ittmaradt földszintes házak váltják egymást a múltszázad második felében épült két-háromemeletes bérházakkal, egy-egy üzemi jellegư épülettel, üres telekkel, telephellyel, téglaburkolatú iskolaépülettel, néhol egy-egy sarkon kiugró IV-V emeletes szecessziós bérházzal.

A közlekedés fổ irányai ugyan elkerülik, de megközelíthetôsége mégis jó. Belsổ keresztutcái viszonylag csendesek, hosszirányú utcái forgalmasabbak.

A hiányos, szaggatott beépítésũ területen a lakóházak mellett elsôsorban helyi jelentôségư közintézmények találhatók: iskola, óvoda, rendelô, rendốrkapitányság, stb. A régiek mellé az utóbbi években újabbak is épültek.

A jellemzố sok üres telek, telephely mellett a beépített telkek nagymértékben kihasználtak, ami azt jelenti, hogy igen kevés a belsổ kert, kisméretũek a belső udvarok. Hiányzik a park, a zöld, a játszótér!

A lakások kb. $45 \%$-a komfortnélküli és egyszobás!

A Rákóczi tértốl keletre fekvổ tömbök és utcák életére rányomja bélyegét az egyre nagyobb területre kiterjedố prostitúció.

Ezen a környéken, talán a kis telekméreteknek köszönhetổen, a régi földszintes házak közül sok maradt meg magántulajdonban. Az utóbbi években igen sok kft., kisszövetkezet költözött részben a magántulajdonban lévố házakba, részben a bérházak földszintjére, pincéjébe. A pincék átalakulására még az újonnan kialakított borozók nagy száma is jellemzõ.

\section{Javaslataink:}

Ez a terület a városnegyed közepe. Az igen nagyszámú üres telek, telephely és viszonylag sok bontható, elsôsorban földszintes épület lehetôséget ad nagyobb számú lakóház építésére. Ez azért is fontos, mert még a meglévô lakóépületek többségének megtartása esetén is lakásszám csökkenés várható, hiszen a meglévổ lakások kb. 45\%-a komfort nélküli vagy szükséglakás. De lakásszámcsökkenés várható a kiemelt lakóépületek funkcióváltása miatt is. A beépítési arányokat és magasságot, az épületek léptékét az utcák keskenysége, és a viszonylag kis telekméretek azonban korlátozzák.

A lakóépületek mellett alkalmasnak tartjuk a területet kisebb szállodák, irodaházak elhelyezésére. Kedvezô ez a terület a kisvállalatoknak is.

Egy dologra azonban fel szeretnénk hívni a figyelmet. Az iskolák általában helyhiánnyal küzdenek, és többnyire nincs megfelelố közösségi termük, tornatermük, udvaruk. Ezért a meglévó iskolák melletti üres vagy megüresedó telkeket elsösorban iskola-bôvitésre, és az iskolához csatlakozó park kialakítására javasoljuk felhasználni.

A terület nemcsak a helyi szintũ közintézmények, de a józsefvárosi iparosság kisüzemeinek is a helyszíne volt. Az oly gyakran előforduló, lakóház-udvarból nyíló, elhagyott, de építészetileg értékes kisüzemeket, mưhelyépületeket a jövốben újra munkahelyteremtố lehetốségként lehet számontartani, hiszen a munkahelyteremtés rendkívül fontos a régi, leértékelődött városrészek újjászületése esetén. 
Perczel Anna : A Közép-Józsefváros északi területére készülő részletes rendezési terv programja (Detailed plan and program of the Northern part of Central-Josephstadt in Budapest)

Tér és Társadalom 6. évf. 1992/3-4. 89-162. $p$.

A terület felértékelốdését elốsegítheti a forgalomcsillapitott közlekedési zóna bevezetése, és a tervezett új parkok kialakitása is. A sû́rú beépítés oldásának lehetôsége a Déri Miksa utcaFecske utca-Auróra utca találkozásánál magától kínálkozik. Az itt bontásból keletkezett, Rendelơintézet elốtti teresedéssel együtt ez a rész átvezethet a Mátyás tér felé, bốvítve ezzel a városi életben újra egyre fontosabbá váló és felértékelổ hatású köztéri zöldterületet. Ez egyben esztétikai értelemben is segíthet feloldani ezt a lakótelepi stílusban megfogalmazott, ide nem illố térbớvületet.

Városszerkezeti szempontból megkülönböztetett szerepe van a Déri Miksa utca mellett a József utcának is, hiszen ez az egyetlen - a Belsổ Józsefvárosból induló és a Fiumei útig végigfutó - hosszirányú belsố utcája nemcsak ennek a területnek, de az egész városrésznek is. A korábbi tervek és elképzeléseink szerint is forgalomcsillapított esetleg sétáló és kerékpáros utca lehetne a prostituált negyed jelenlegi ,,fôutcájából”.

Nyitott és egyenlổe nem megválaszolható kérdés az eredetileg korlátozott területen mứködổ prostituált negyed egyre korlátlanabb terjeszkedése és ennek következményei.

Olyan, a nagyvárosok életéhez tartozó hagyományos jelenségrốl van szó, ahol a városépítészet nem sokat tehet. Igazgatási-rendészeti-szociális-önkormányzati egyeztetések során talán sikerülhet e súlyos terïletleértékelố helyzetnek a lokalizálása. A városnegyedben élố lakók véleménye szerint a Baross utca irányába húzódó terjeszkedés egyértelmưen a József utca és a Tavaszmezổ utca egyirányúsításával kezdổött. Ekkor alakult ki az ún. , kocsisor”. Szerintük a forgalom szervezésével a terjeszkedés befolyásolható. Ezért a József utca és a Tavaszmezô utca, de valójában a környezó utcák esetében is a forgalomcsillapítás, gyalogos elsốbbség, vagy akár az átmenõ forgalom korlátozása a szokásos környezet javító hatáson túl is hasznosnak bizonyulhat.

\section{$C$ terület}

Nagyvárosi munkásbérkaszárnyák, üres telkek, telephelyek és a falu keveredésébót alakult külváros, a leszakadó , harmadik világ"

A Koszorú utca-Baross utca-Kálvária tér-Dobozi utca által határolt városrész, és a Mátyás tér-Teleki tér környéke

\section{Jellemzôi:}

Ez a terület sok szempontból már valódi külváros. A spontán városfejlốdés idején kialakult utca- és térrendszer volt majorsági földek területét tagolta. Ennek megfelelôen a területre a széles utcákkal határolt nagymélységử és nagyszélességû́, szabálytalan trapézalakú, igen nagy méretứ tömbök a jellemzớk, melyek egyes helyeken keskeny, igen mély telkekkel tagoltak. A bérházas beépítéshez nehezen idomítható telekosztás és telekarányok sokáig itt tartották a máshonnan már kiszorult gazdálkodókat, iparosokat. Így a mai napig is számos földszintes lakóház maradt meg, melyek közül jelentốs a magántulajdonban levốk aránya.

A többnyire tekintélyes külsejứ, földszintes lakóházak igen nagy, tágas kertekkel is rendelkeznek, ahol régi kertvendéglớk nyomai is fölfedezhetốk. Ezt a földszintes beépítést leggyakrabban háromemeletes munkásbérkaszárnyák váltják váltakozva az üres telkekkel, telephelyekkel, elhagyott üzemépületekkel. Tehát a beépítés a nagy léptékváltások mellett renđkívül hiányos is. 
Perczel Anna : A Közép-Józsefváros északi területére készülő részletes rendezési terv programja

(Detailed plan and program of the Northern part of Central-Josephstadt in Budapest)

Tér és Társadalom 6. évf. 1992/3-4. 89-162. p.
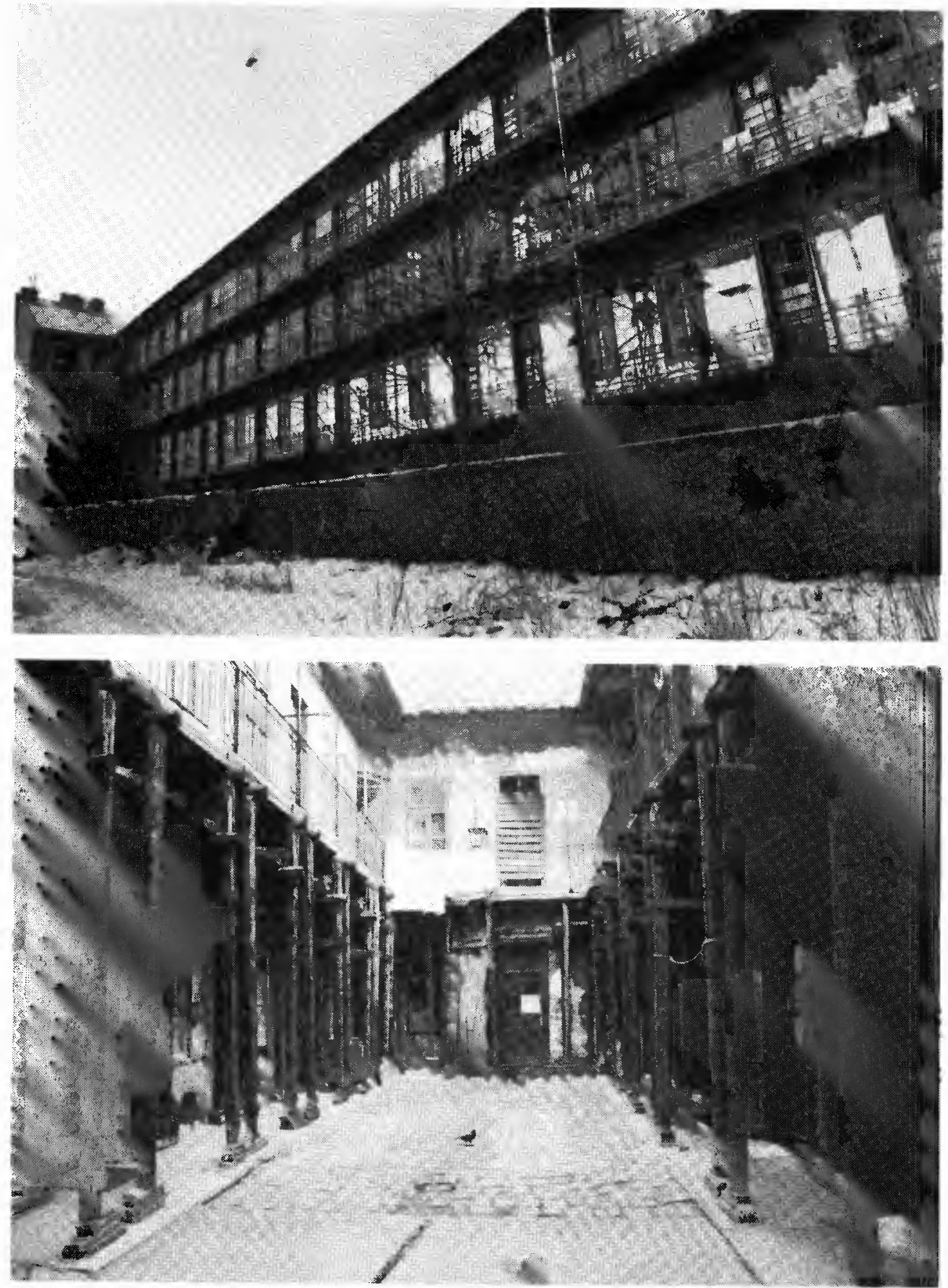

A leszakadó ,,harmadik világ"

Nagyvárosi és kisvárosi jellegũ munkás bérkaszárnyák (Dankó utca 16., József utca 47.). 
Perczel Anna : A Közép-Józsefváros északi területére készülő részletes rendezési terv programja (Detailed plan and program of the Northern part of Central-Josephstadt in Budapest) Tér és Társadalom 6. évf. 1992/3-4. 89-162. $p$.
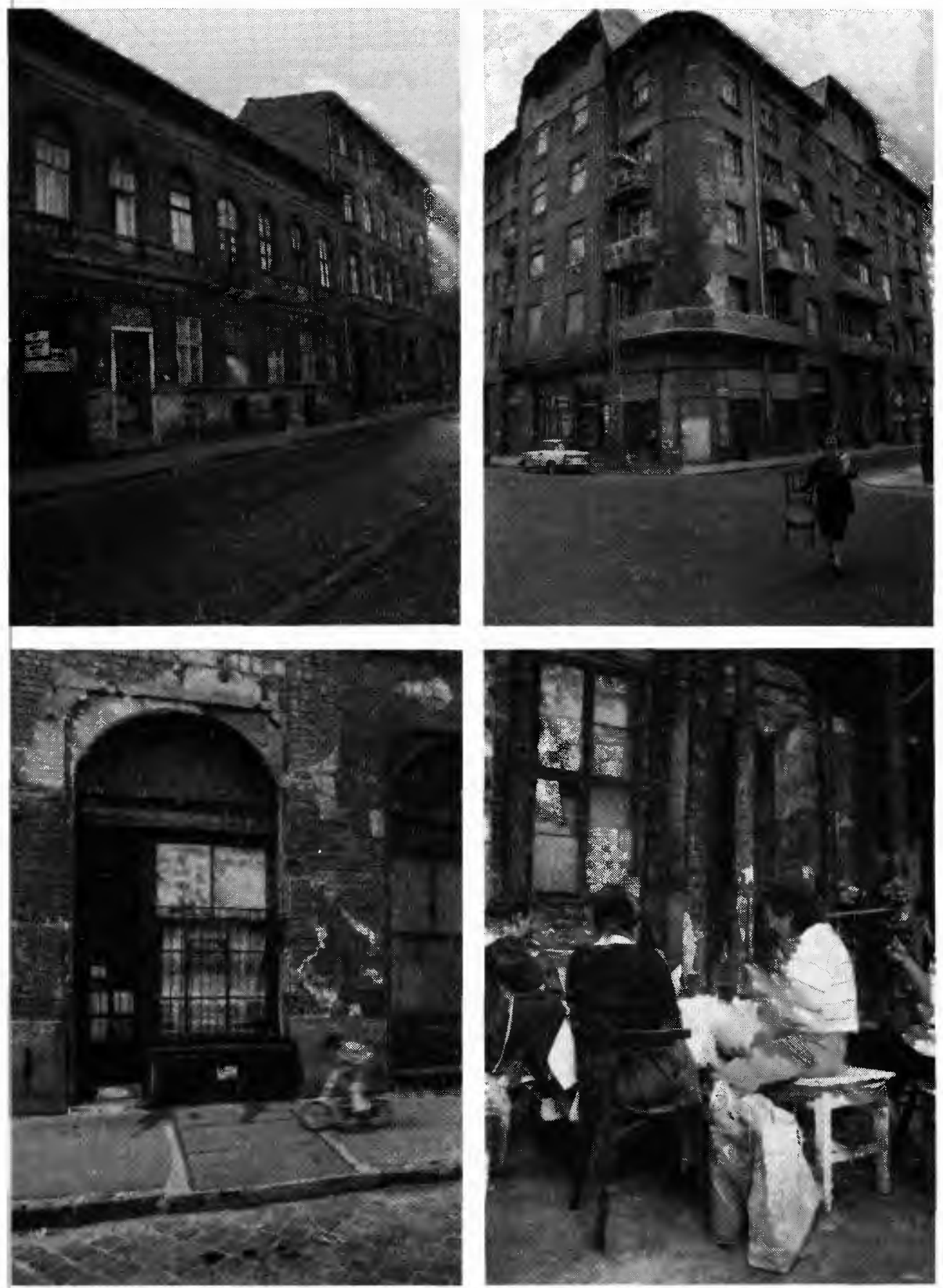

A leszakadó , harmadik világ"

1., 4. Dobozi utca 45., a világ vége, ahol mégis lehet élni. 2. Magdolna utca 40., a Zsibárusház elổtti utca, a játék területe. 3. Karácsony Sándor utca 21., elốkelố bérház a munkásbérkaszárnyák és falusias épületek között. 
Perczel Anna : A Közép-Józsefváros északi területére készülö részletes rendezési terv programja

(Detailed plan and program of the Northern part of Central-Josephstadt in Budapest)

Tér és Társadalom 6. évf. 1992/3-4. 89-162. p.
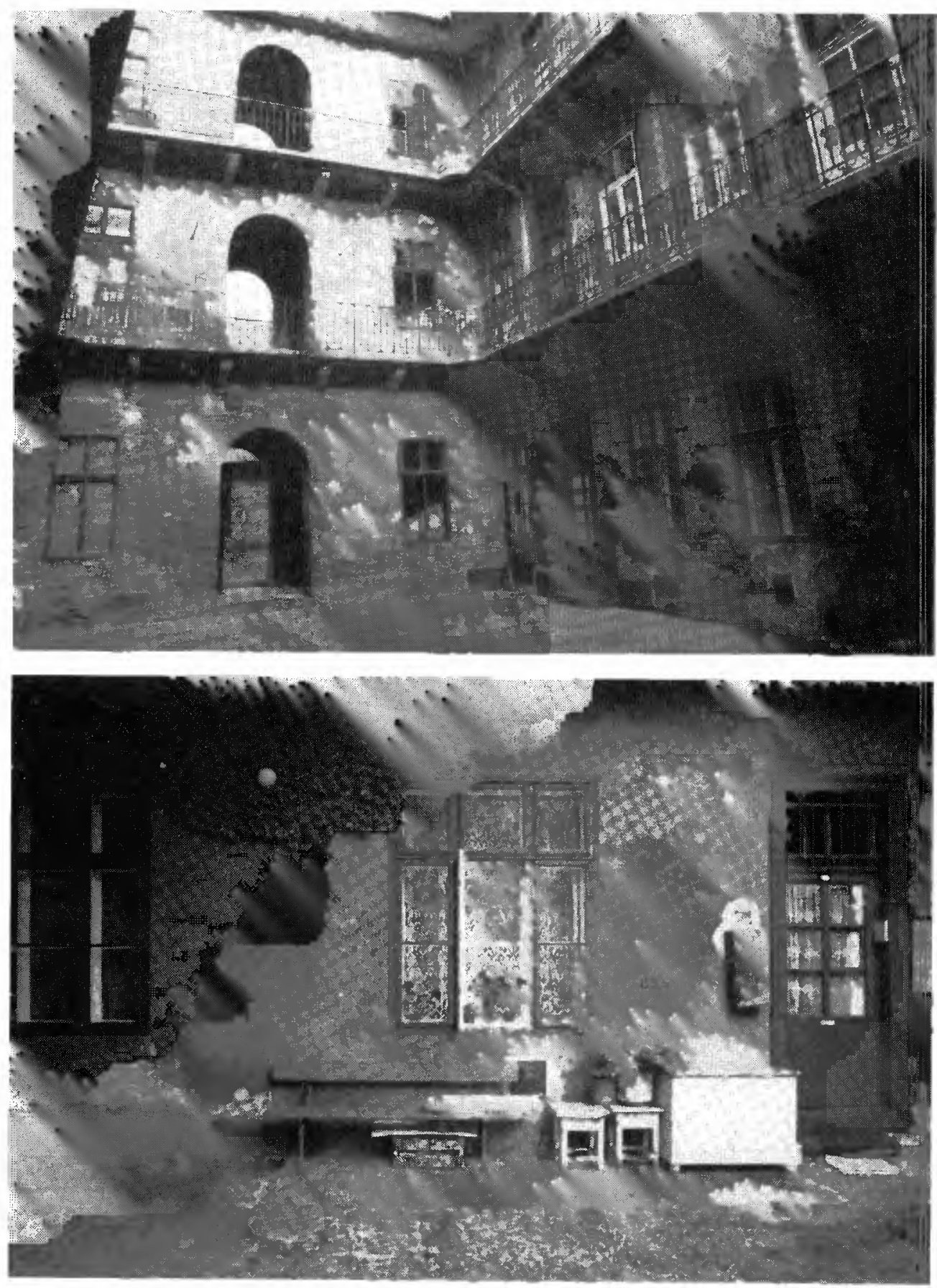

A leszakadó , harmadik világ”.

Munkásbérkaszárnya és a falu idillje egymás mellett. 
Perczel Anna : A Közép-Józsefváros északi területére készülő részletes rendezési terv programja (Detailed plan and program of the Northern part of Central-Josephstadt in Budapest)

Tér és Társadalom 6. évf. 1992/3-4. 89-162. p.

TÉT $1992 \cdot 3-4$

Városrendezés a Józsefuárosban

143

Feltünổ ezen a területen, hogy szinte az egyetlen közintézmény a Fốváros Éjjeli Átmeneti Szálláshelye volt. Még általános iskola sincs.

A lakáshelyzet itt a legrosszabb, szinte Dickens-i világba illô, hisz a lakások kevesebb mint 35\%-a a komfortos; $70 \%$-a egyszobás!

Ez olyan arány, és olyan súlyos probléma, ami helyi szinten már nem kezelhetô. Paradox módon azonban épp ez a legrosszabbnak tứnố terület az, amely a levegổ minốsége tekintetében kedvezốbb helyzetben van, mint a szomszédos városrészek.

A területnek feltünổen nincs üzleti élete sem, de ugyanakkor a városnegyed iparosságának, mesterembereinek jelentốs része él máig is itt (elsôssorban a Magdolna utcában és annak környékén). Kivétel ez alól a Teleki tér környéke, melynek életét bár megtépázva, de még mindig meghatározza a kiskereskedelem, és maga a piac.

A terület építészeti és szociális leromlása ellenére az utóbbi években - talán a szerkezeti struktúra és a környezeti adottságok miatt - három nagyobb társasház is épült a környéken. Ugyanakkor az is jellemzô, hogy a rossz lakások miatt egyetlen lakás megvételére sem került itt sor.

Mégis úgy véljük, hogy a Közép-Józsefváros ma e leghátrányosabb helyzetûnek tửố része komoly, a kimozdulást segítố potenciális lehetổségekkel rendelkezik.

- változás várható az Orczy tér irányából, mely ma még lehangolóan városszéli közlekedési csomópont csupán;

- felértékelố hatású lesz, illetve lehet erre a területre a Józsefvárosi Pályaudvar tervezett átalakulása: a jelenlegi konténerpályaudvar-szerep megszủnése; és az elốvárosi személyforgalom megerôsödése, növekedése.

- a területet a Fiumei út felốl lehatároló, és kibontakozását egyben gátló, Baross Remiz funkcióváltása, ennél megfelelóbb területre költözése, felértékelő hatású lehet nemcsak az Orczy térre, de a környék egészére is;

- igen nagy potenciális épitési lehetôséget jelent a területen nagy arányban található beépíthetô üres telek, telephely, melyek mértékét még az elbontható épületek viszonylag nagy száma is növeli.

\section{Javaslataink:}

—Ez az a terület, ahol a szokásosnál is súlyosabb a társadalmi-környezeti leépülés, ritka\ágszámba megy a komfortos lakás. Itt gyülekeznek az ún. munkásbérkaszárnyák, itt a legnagyobb méretú a szlöm, a szegregáció. Kisebb területfelértékelố beavatkozások, akciók önmagukban itt egyáltalán nem segítenek. Radikális, de igen meggondolt és differenciált cselekvés, beavatkozás szükséges. Az eddigi imereteink alapján úgy gondoljuk, hogy ebben az esetben ,új típusú” lakásépítési akciót kellene végiggondolni. Még az értékesebb épületek megtartása esetén is bôséges hely áll majd rendelkezésre nagyobbszámú magasszínvonalú bérlakás, társasház, és ún. ,városi ház" megépítésére. A rendkívül tágas, nagyméretứ tömbökben a széles utcák mentén a lakásépítést vonzớvá teheti a levegổ jobb minổsége, a nagyobb összefüggó belsố zöldterületek, vagy egyéni kertek kialakításának lehetôsége. De esélyessé teszi ezt a területet az egyre nagyobb értéket jelentố közterek, parkok, zöldterületek közelsége is (Teleki tér, Mátyás tér, Kálvária tér, Köztemetố).

Az azonban bizonyos, hogy a leépülés ilyen dimenziója pusztán helyi, önkormányzati erốvel nem oldható fel! 
Perczel Anna : A Közép-Józsefváros északi területére készülő részletes rendezési terv programja

(Detailed plan and program of the Northern part of Central-Josephstadt in Budapest)

Tér és Társadalom 6. évf. 1992/3-4. 89-162. p.

144 Perczel Anna

TÉT $1992 \cdot 3-4$

Ahhoz, hogy valóban elinduljon itt ez az ,,új típusú” lakásépítés, például szükség lesz a már most is hiányzó általános iskola, óvoda, bölcsổe, rendelố, stb. építésére, vagy kialakítására is. Ugyanakkor itt nyílik lehetổség az egész városrész életét is komolyan felértékelő nagyobb területigényú sportolási létesítmények pl.: uszoda elhelyezésére. A nagyobb területũ és mélységû telkek, a funkcionálisan vagy minôségileg átalakítható földszintes, egyemeletes lakóépületek jó lehetôséget kínálnak kisebb környezetbarát (ipari) vállalkozások idevonzására is.

Az egész terület jövôjét, de különösen a Dobozi utca menti igen nagy tömb további sorsát meghatározóan befolyásolja a Baross Remiz kiköltöztetése a jelenleginél alkalmasabb területre. Ha ez megtörténne, a városrésznek ez a leszakadó területe fellélegezne, kinyílna, és végre hozzákapcsolódhatna a város életéhez. A Remiz helyére, a csarnoképület egy részének felhasználásával, esetleg átkerülhetne a Teleki téri piac, míg az Orczy tér felöli területén kereskedelmi központ is kialakítható lenne, ami feltûnổen hiányzik a városnak ezen a pontján.

A Dobozi utca elképesztổ világvége jellege mellett a városrész legrosszabb helyzetû, ám XIX. századi beépítését legteljesebben ốrzố utcája a Lujza utca. Különleges utcának tartjuk még itt a törtvonalú Koszorú utcát és Magdolna utcát is. Ez a három utca a jellegzetes józsefvárosi földszintes és egyemeletes házak sorát őrzi még. Védelmükkel, új élettel való megtöltésükkel a városrész különleges, elsố beépülési korszakát képviselố utcáiként idegenforgalmi szerepet is betölthetnek majd.

A nagyobb elhatározásoknál, vállalkozásoknál könnyebben megvalósítható területfelértékelô lehetốségek ez esetben is a közlekedés rendjének átgondolásában, a szélesebb utcák. (Dankó utca, Karácsony S. utca) fasorral történő beültetésében, új zöldterületek kialakításában rejlenének, elsố bíztató, kiinduló lépésként.

\section{A terek megkülönböztetett jelentôsége a rehabilitációs folyamatban: akcióközpontok}

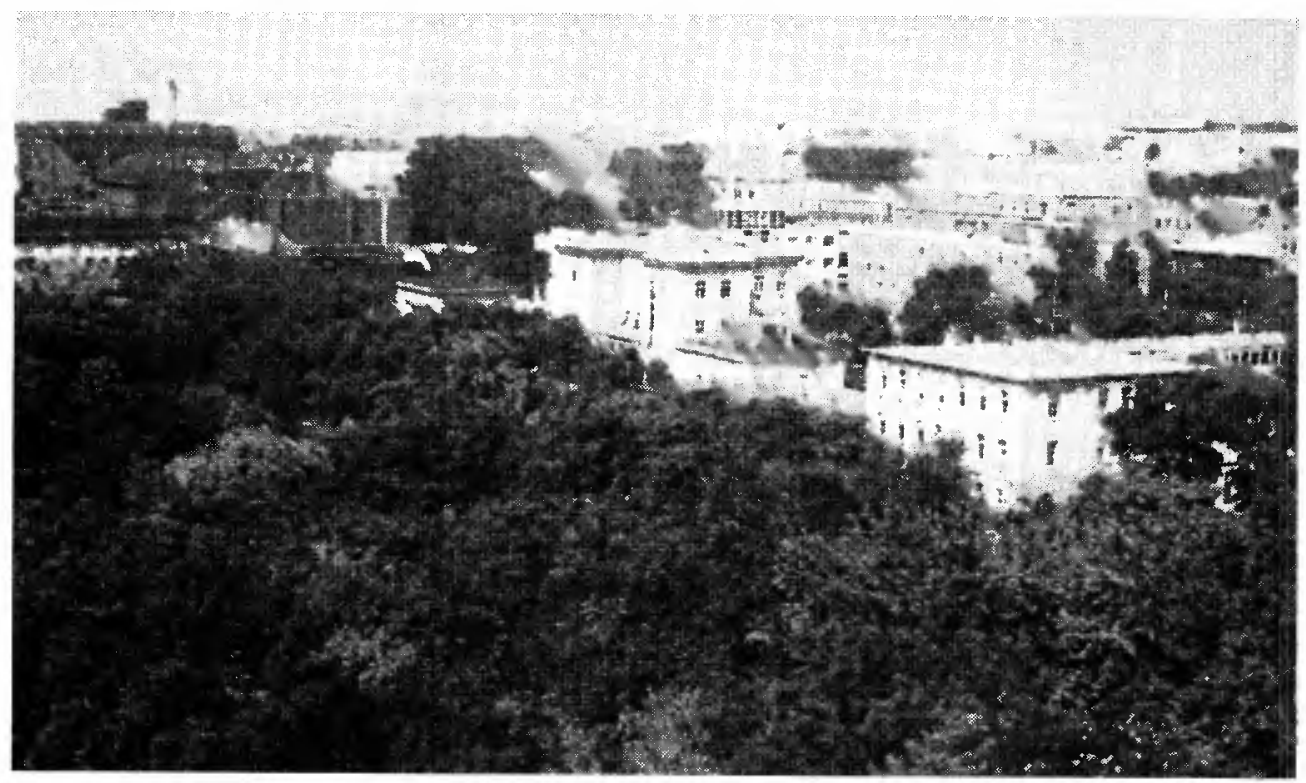


Perczel Anna : A Közép-Józsefváros északi területére készülő részletes rendezési terv programja (Detailed plan and program of the Northern part of Central-Josephstadt in Budapest)

Tér és Társadalom 6. évf. 1992/3-4. 89-162. p.

A városi terek és parkok különleges helyet jelentenek, és megkülönböztetett szerepük van a városok, a városban élố emberek életében.

Itt, a Józsefvárosnak ezen a részén, a fôvárosban egyedülálló módon igen nagyszámú tér és park található szinte egyenletesen elhelyezkedve és egymáshoz is kapcsolódva. A közterek és parkok ily nagy száma és egymástól oly eltérổ, különbözö jellege különlegesen értékessé és izgalmassá teszik a városnak ezt a részét.

Mégis minden adottságuk, szépségük és egyediségük ellenére e városrész tereinek többsége nem tölti be azt a vonzó, sugárzó, felértékeló szerepet, ami általában sajátja a városi tereknek.

Más a helyzet a fớutvonalakhoz kapcsolódó tereknél, hisz esetükben elsôsorban az óriási méretứ, kíméletlen, rosszul szervezett, és elfogadhatatlan minőségủ forgalom zilálja szét, teszi eleve alkalmatlanná óket arra, hogy városi , agora" szerepüket betölthessék.

Más a helyzet a belsố, zártabb terek esetében, ahol egyértelmûen a terület szaggatott fejlổésének és fokozódó leértékelổdésének okai hatnak oly erôvel magukra a terekre is, hogy nem, vagy csak félig-meddig tudják betölteni azt az elementárisan fontos városi funkciót, amire ki lettek találva.

Ezeknek a tereknek a beépítése - egy-két kivételtôl eltekintve - még a mai napig is oly hiányos, hogy kivételes építési-vállalkozási lehetôségeket is nyújtanak.

Az egész városnegyed helyzetét, életét felértékelő folyamatok elindításában ezért kiemelkedổ jelentőséget tulajdonítunk a terekkel összefüggõ akcióknak. Egyáltalán nem mindegy milyen célra, milyen összefüggésben, milyen színvonalon, milyen funkcióval épülnek majd be az üres telkek. Példaként négy egymástól igen különbözổ helyzetú és karakterũ teret emelünk ki, hogy rávilágítsunk mire is gondolunk.

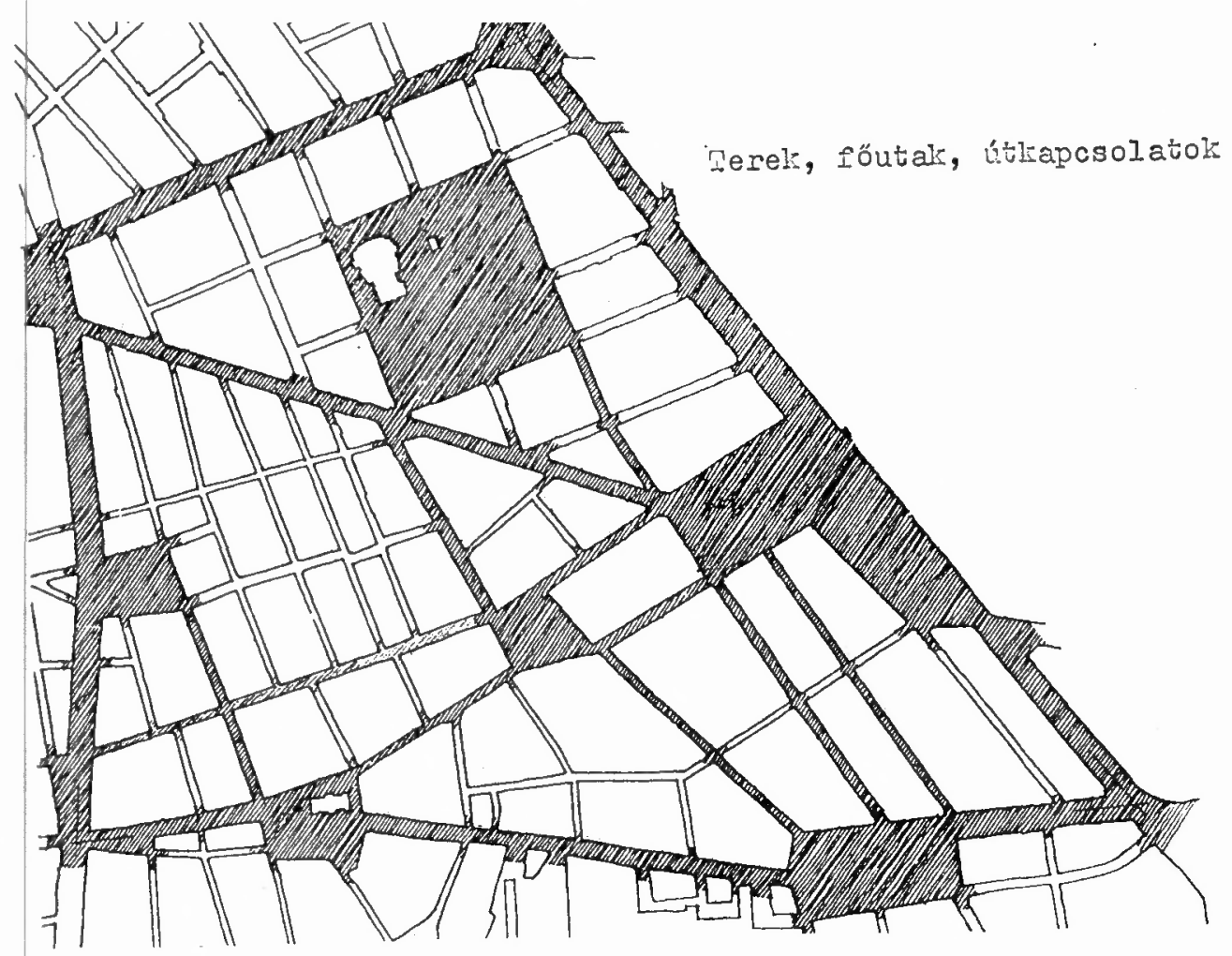


Perczel Anna : A Közép-Józsefváros északi területére készülő részletes rendezési terv programja

(Detailed plan and program of the Northern part of Central-Josephstadt in Budapest)

Tér és Társadalom 6. évf. 1992/3-4. 89-162. p.
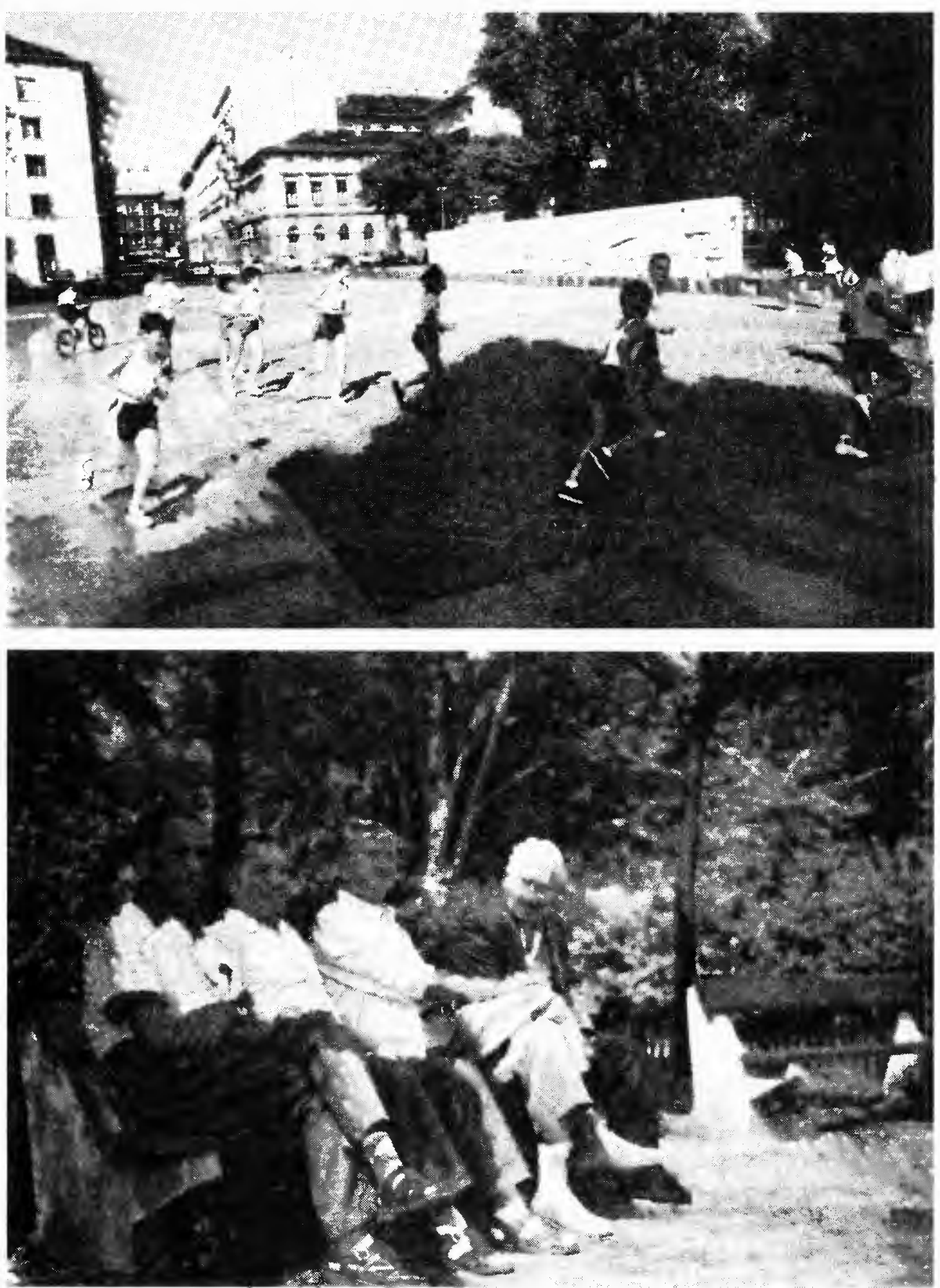

Hétköznapi délután a Köztársaság téren. 
Perczel Anna : A Közép-Józsefváros északi területére készülő részletes rendezési terv programja (Detailed plan and program of the Northern part of Central-Josephstadt in Budapest) Tér és Társadalom 6. évf. 1992/3-4. 89-162. p.

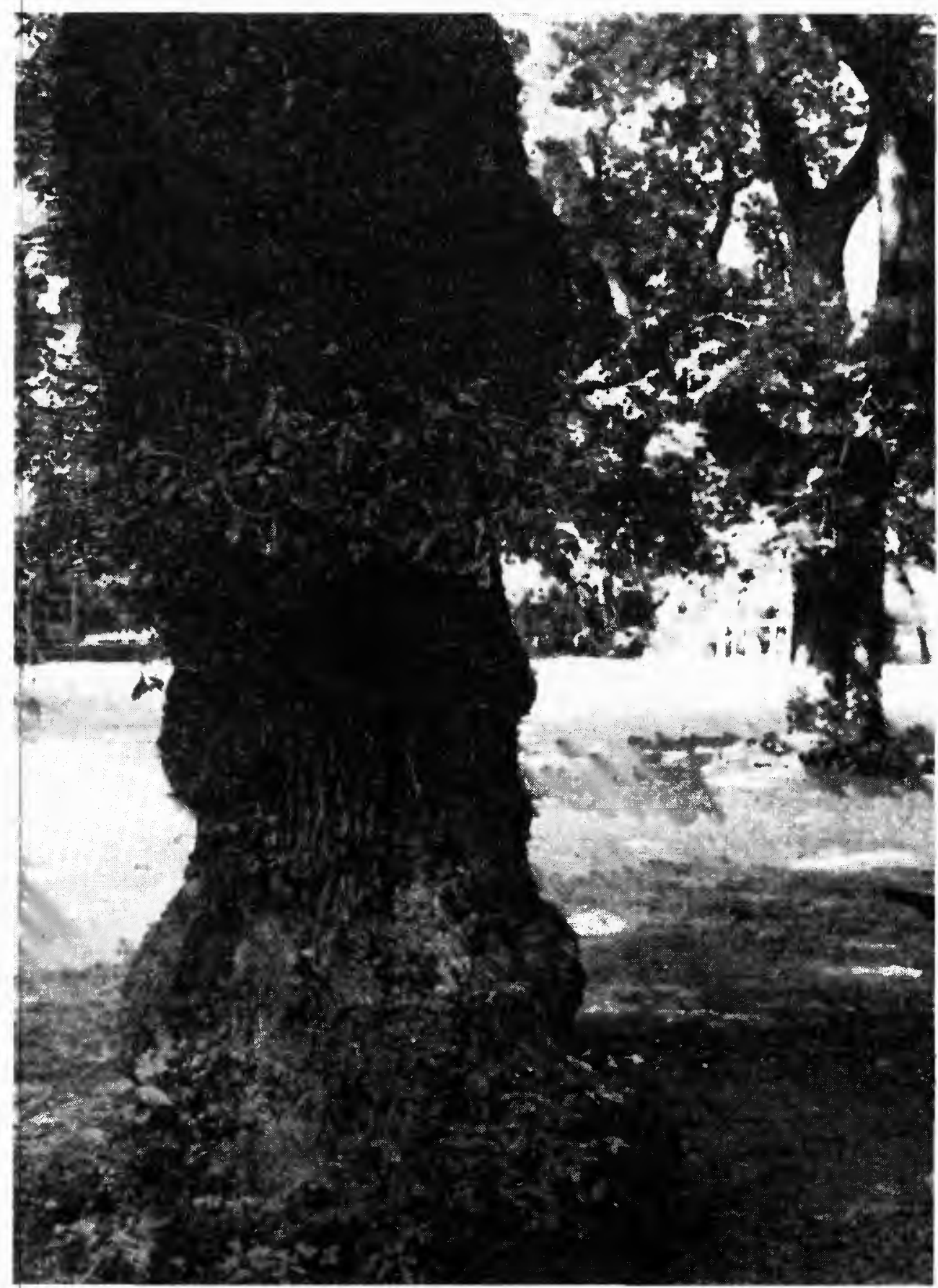

A Köztársaság tér fái. 
Perczel Anna : A Közép-Józsefváros északi területére készülő részletes rendezési terv programja

(Detailed plan and program of the Northern part of Central-Josephstadt in Budapest)

Tér és Társadalom 6. évf. 1992/3-4. 89-162. p.

Köztársaság tér

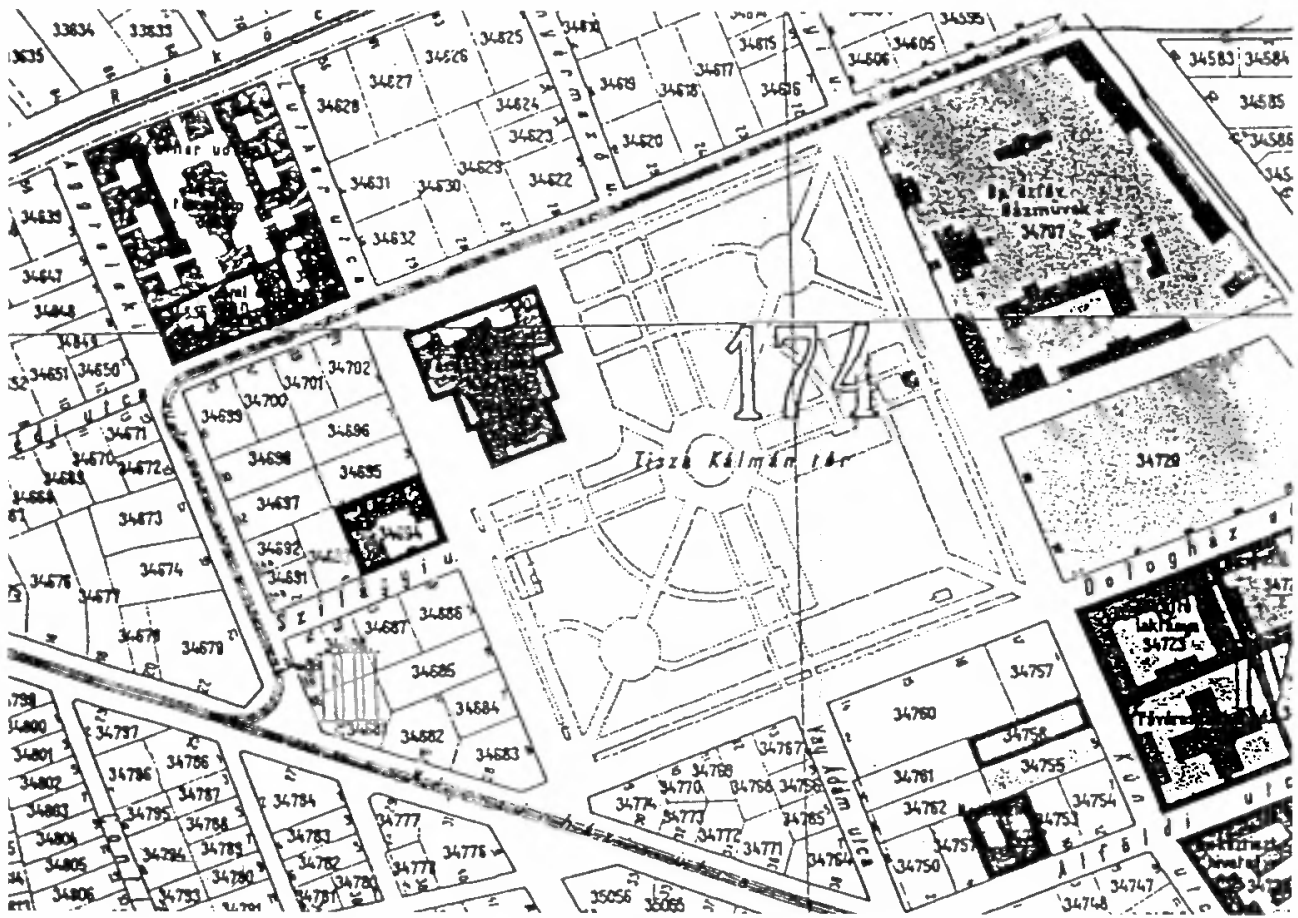

A hajdani lóvásár majd piactér 6 hektáros területét 1897-ben parkosították. Budapest legnagyobb köztéri parkja városszerkezetileg és városépítészetileg is jelentőss alkotás. A kertépítészet hagyományait követố geometrikus elrendezésének teljes gazdagságban történő helyreállítása, a környezố funkciók elsősorban kulturális többlettel való feltöltése a fôváros legértékesebb helyeinek egyikévé emelhetné az ökológiai és társadalmi szempontból már ma is igen jelentős teret.

\section{Mátyás tér}

Ez a tér a városrész közepe, szive, és bár még tömegközlekedés szempontjából is elổnyös helyzetben van, a teljes leépülés jellemzi. Foghíjak, tũzfalak, üres területek, kiemelkedốen magas öt-hatemeletes, századfordulón épített bérházak, és földszintes épületek váltakozása jellemzi. Bérházainak építészeti kvalitásai sok esetben a Népszínház utca bérházaival azonosak.

Ez az a tér is, amelyikról szinte az összes többi tér felé utca vezet.

Nagyszámú beépítetlen telke lehetôvé teszi olyan új funkciók kialakítását is, mely egyszerre szolgálná az itt élố embereket, de egyben vonzó lehetne akár az idegenforgalom számára is. A tér méretei azt is lehetốvé teszik, hogy megerősödjön, illetve lehetôvé váljon a közterek egyik legfontosabb funkciója: a pihenés-séta-játék lehetôsége is. A ma igen kopottas és elhanyagolt park növényzetének kiegészítése, játszóterének gazdagítása akár azonnal is lehetséges, mint elsố bíztató lépés az önkormányzat részérôl. 
Perczel Anna : A Közép-Józsefváros északi területére készülő részletes rendezési terv programja

(Detailed plan and program of the Northern part of Central-Josephstadt in Budapest)

Tér és Társadalom 6. évf. 1992/3-4. 89-162. p.
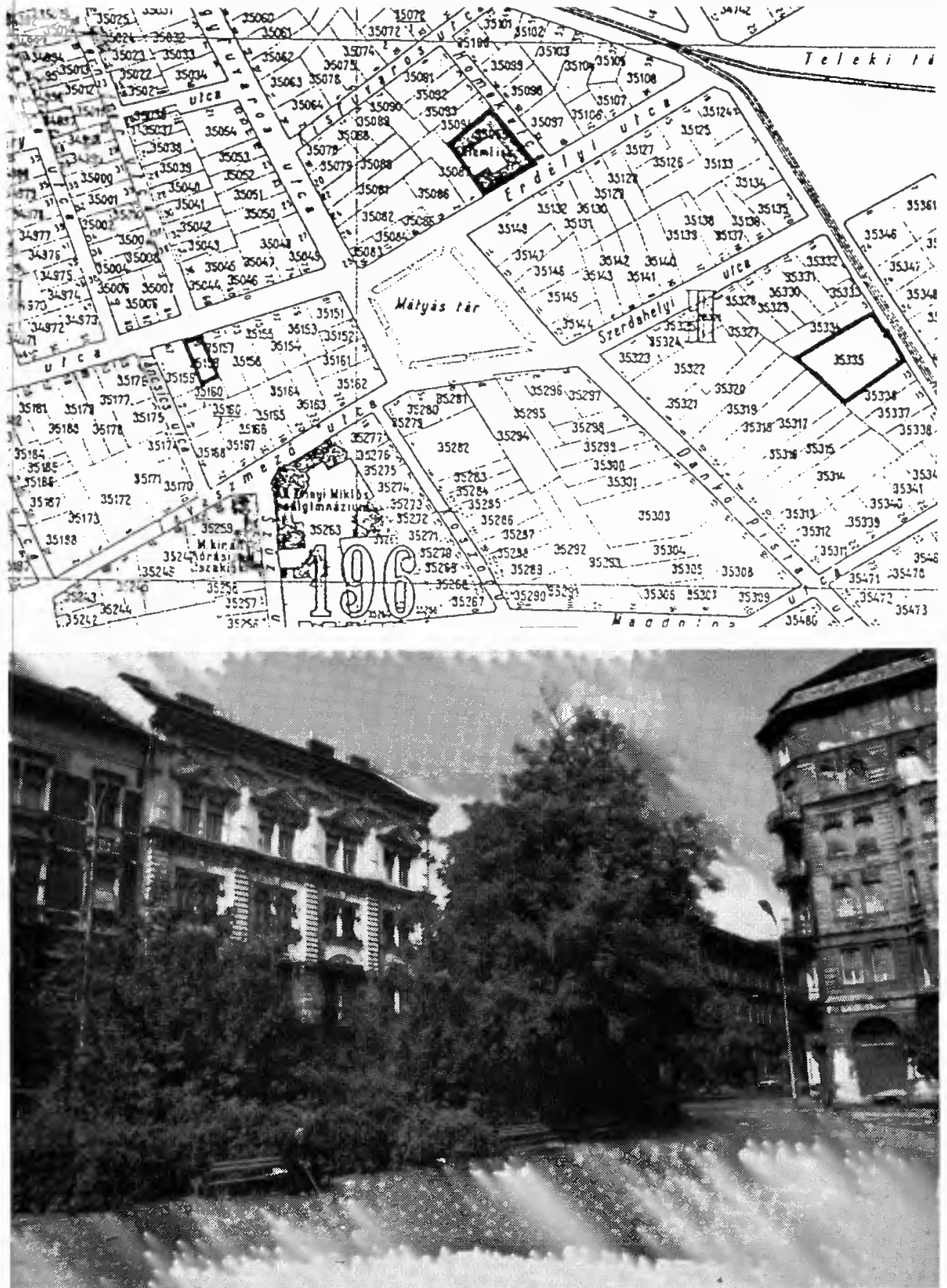

Mátyás tér. 
Perczel Anna : A Közép-Józsefváros északi területére készülö részletes rendezési terv programja

(Detailed plan and program of the Northern part of Central-Josephstadt in Budapest)

Tér és Társadalom 6. évf. 1992/3-4. 89-162. p.
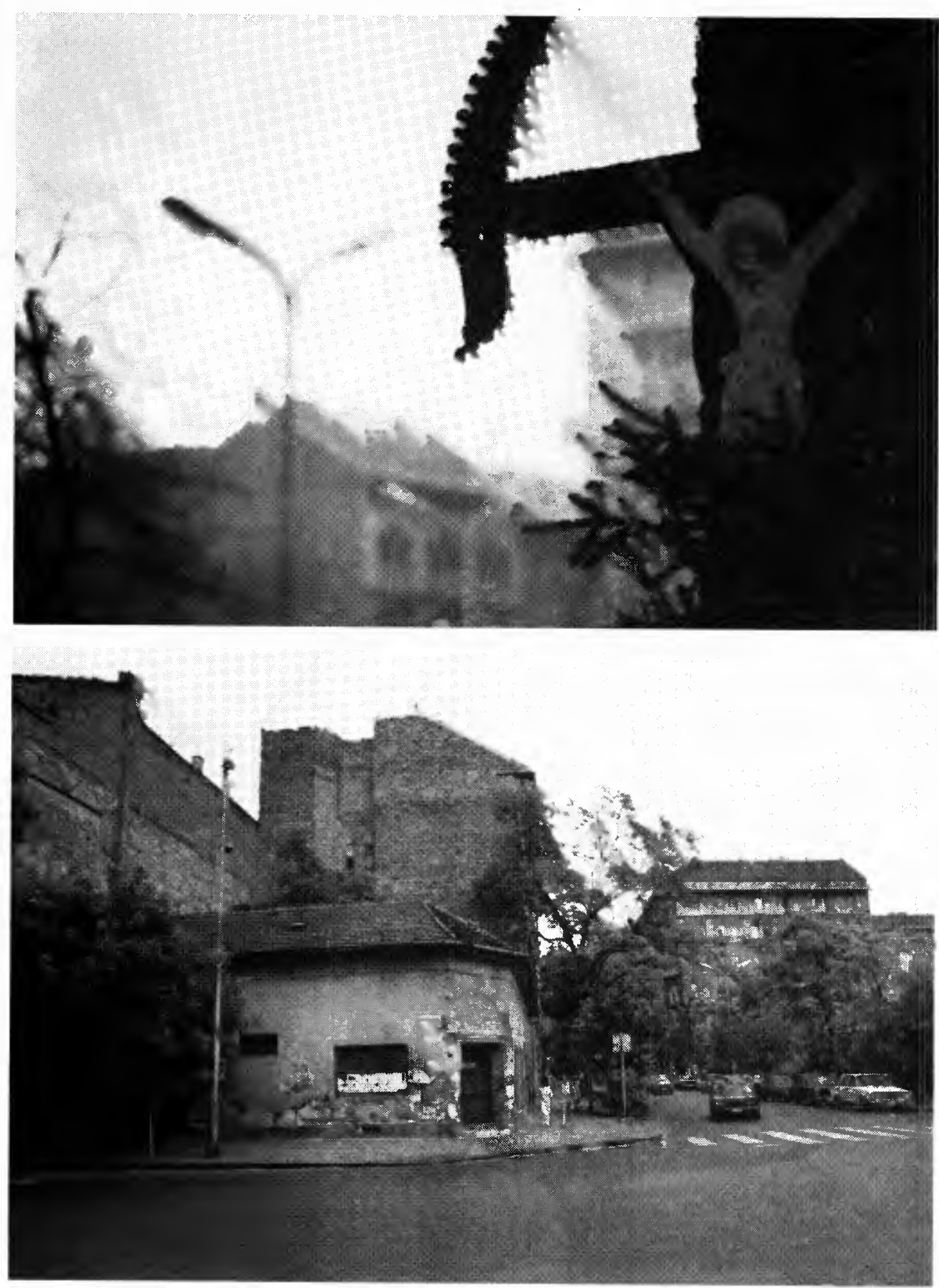

A Mátyás tér a pesti oldal talán egyedüli megmaradt pléhkrisztusával. 
Perczel Anna : A Közép-Józsefváros északi területére készülő részletes rendezési terv programja (Detailed plan and program of the Northern part of Central-Josephstadt in Budapest)

Tér és Társadalom 6. évf. 1992/3-4. 89-162. p.

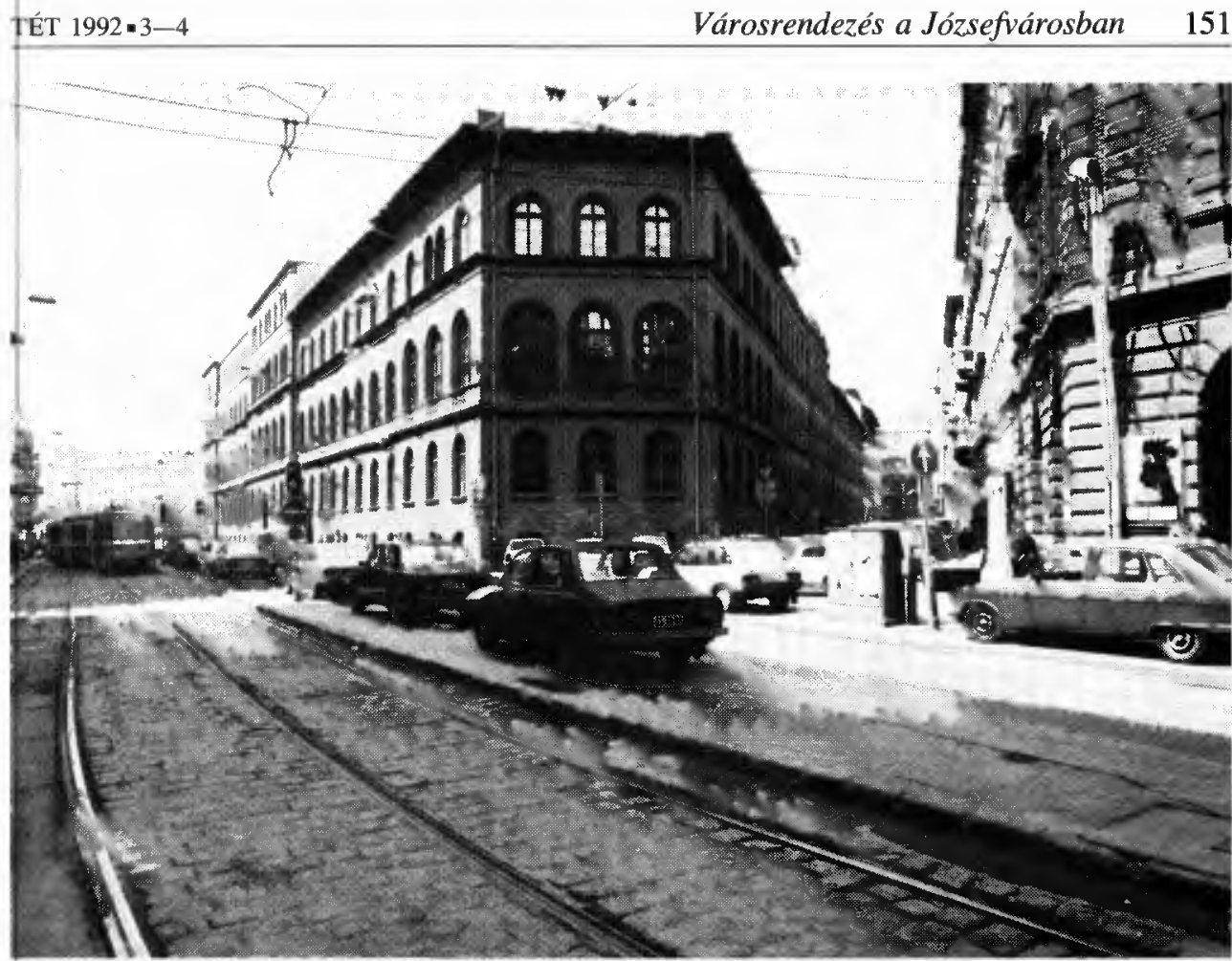

Népszínház utca

Mint tiszteletbeli tér, fórum, tengely, különleges szerepet tölt be a , régi" és az , ,új”, a ,polgári" és a „szegény" világ, a bel-és külváros között.

Századfordulón épült bérházainak karaktere és építészeti minôsége - túlnô még a Köztársaság tér környékének beépítési színvonalán is. Ez az egyik legnagyvárosiasabb utcája a Józsefvárosnak, talán a fổvárosnak is, időnként a századforduló Chicagójára emlékeztetổ. Vízuális és funkcionális térkapcsolatát a Blaha Lujza térrel azonban fel kellene erôsíteni, meg kellene -idani. Legyen fórum, sétatér, korlátozott forgalommal, hátrahúzott villamos végállomással, kisebb klubok, egyesületek számára kulturális célra felajánlott termekkel, mozikkal, vendéglókkel és természetesen üzletekkel!

A Népszínház utca szerepének felértékelôdése ugyanakkor szoros összefüggésben van a Teleki térrel is, annak felértékelôdése pedig hiányzó beépítésén túl a piac jövôbeni szerepével sorsával. 
Perczel Anna : A Közép-Józsefváros északi területére készülö részletes rendezési terv programja

(Detailed plan and program of the Northern part of Central-Josephstadt in Budapest)

Tér és Társadalom 6. évf. 1992/3-4. 89-162. p.
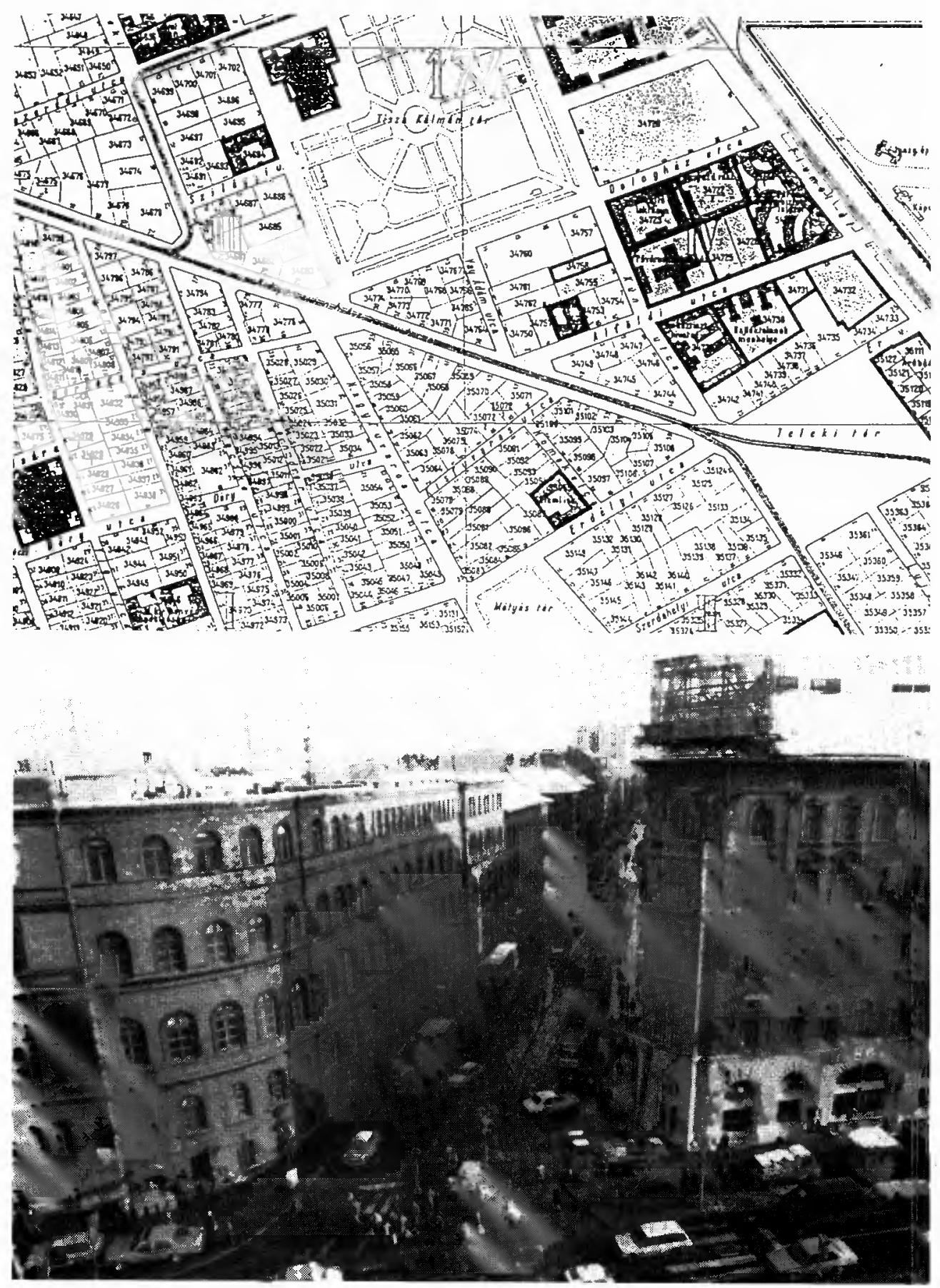

A Népszínház utca szokatlan, átlós vezetése és körúti torkolata. 
Perczel Anna : A Közép-Józsefváros északi területére készülő részletes rendezési terv programja

(Detailed plan and program of the Northern part of Central-Josephstadt in Budapest)

Tér és Társadalom 6. évf. 1992/3-4. 89-162. p.

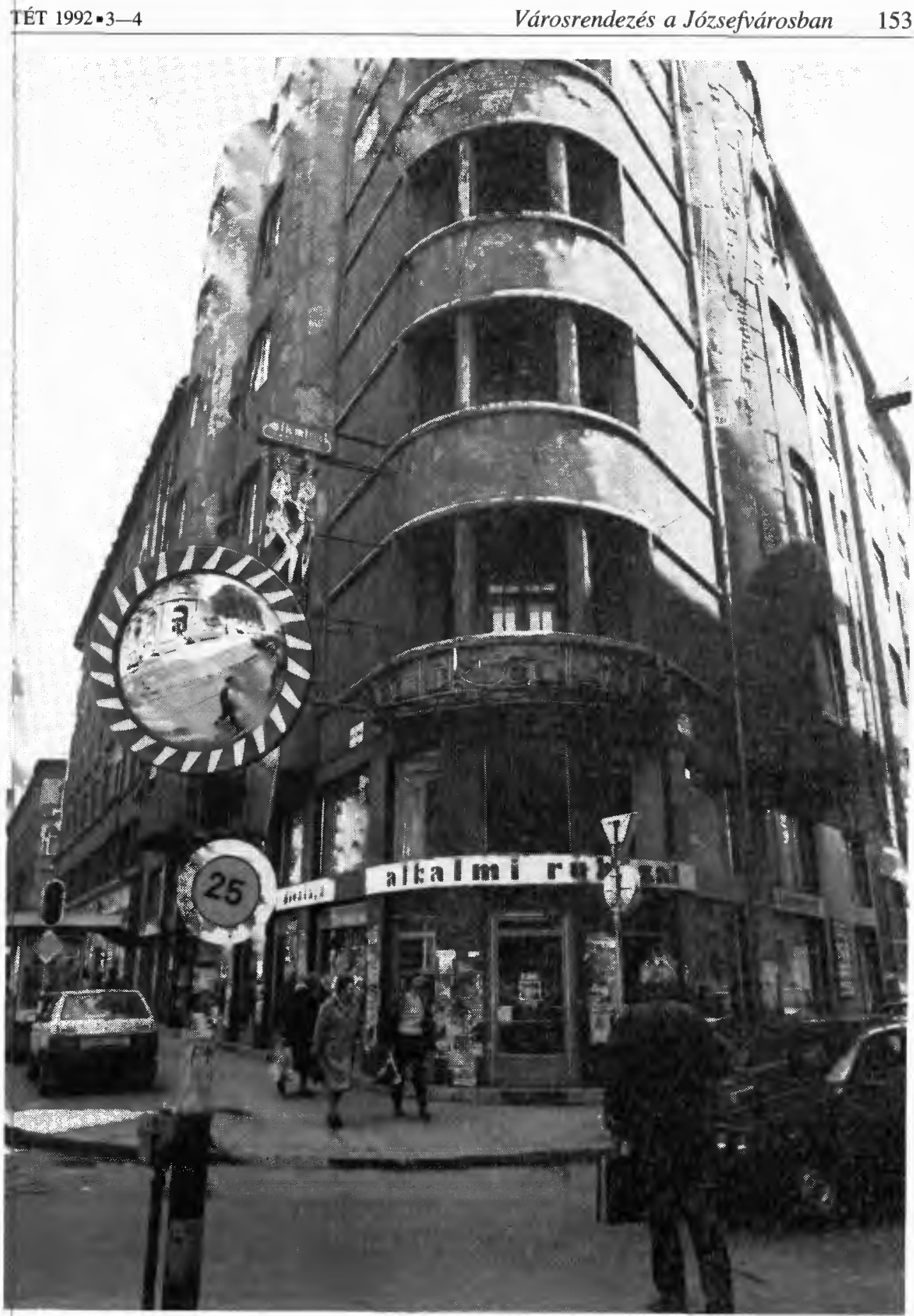

A Népszínház utca különleges saroképületeinek egyike. (Lajta Béla, 1912). 
Perczel Anna : A Közép-Józsefváros északi területére készülő részletes rendezési terv programja

(Detailed plan and program of the Northern part of Central-Josephstadt in Budapest)

Tér és Társadalom 6. évf. 1992/3-4. 89-162. p.

TÉT 1992-3-4

\section{Rákóczi tér}

Ez itt az a szinte egyetlen, teljesen kialakult, beépített városi tér és park, ahol a környezố lakóházak földszintjei ma is a városrész lakóinak életéhez kapcsolódnak.

Tehát leépülése és zứrzavaros állapota ellenére élô, valóságos városi tér maradt, talán a Nagykörút közelségének és a Vásárcsarnok jelenlétének együttes hatására. Leépülését azonban nem lehet tagadni, melyhez hozzájárul az is, hogy hajdani park jellegét megbontva játszótérré változtatták át. Mindez a városnak e rettenetesen szennyezett levegôjứ, védtelen helyén elfogadhatatlan! A csarnok mögötti új park, játszótér kialakításával szeretnénk ezen változtatni úgy, hogy helyette helyreálljon a tér századfordulón kialakult jellege: középen szökőkút, szoborcsoport, körös-körül alacsony öntöttvas kerítés, sok fa és zöldfelület.

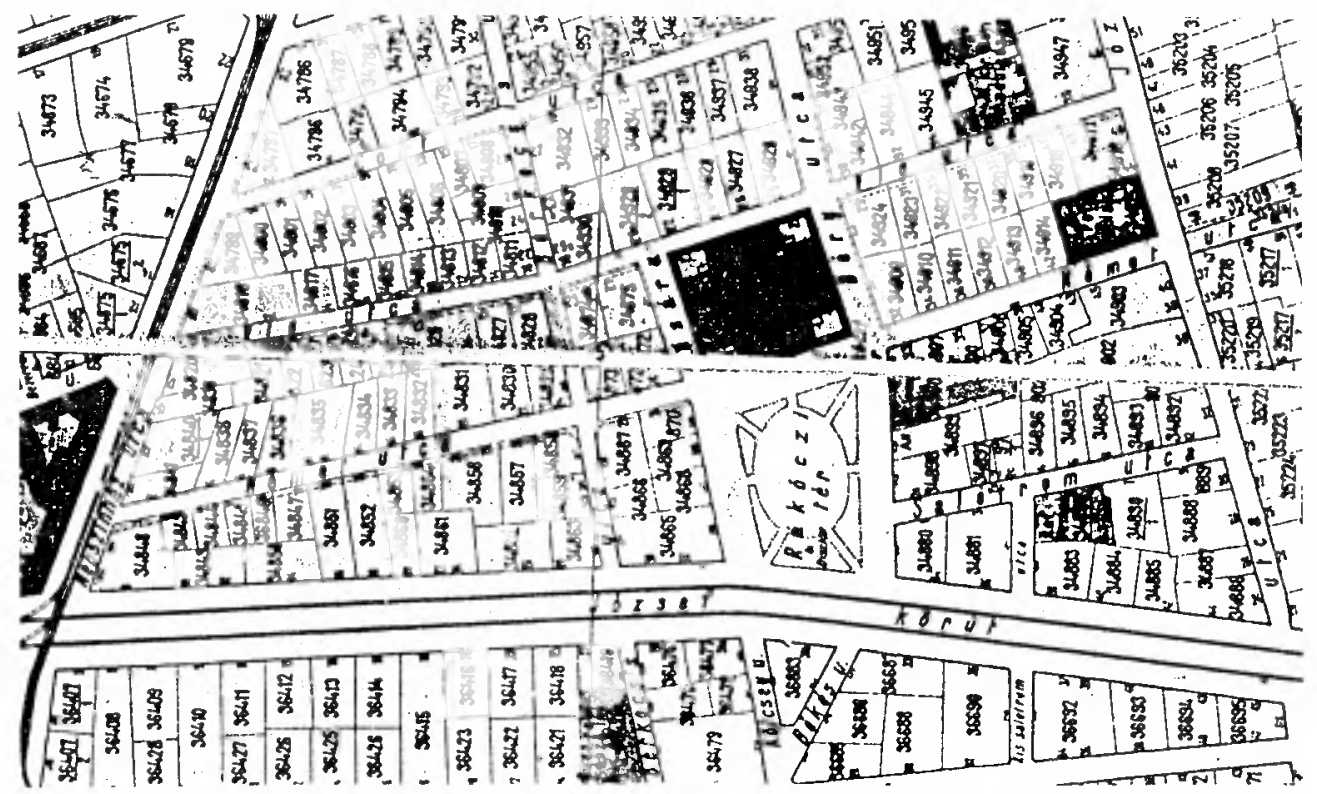

\section{A közösségi és félközösségi terek jelentósége}

Nemcsak a terek és parkok, de az utcák, tömbbelsốk, udvarok, kertek, sốt függôfolyosók (gangok) is fontos színterei a városi életnek, a közlekedés és vásárlás mellett a találkozásoknak, sétának és pihenésnek.

Nyári délutánokon ebben a városrészben gyakran lehet látni az udvaron, kertben, függơfolyosón ülố, egymással beszélgetổ embereket, kertekben játszó, vagy a kevésbé forgalmas utcákban ugróiskolázó gyerekeket, de még a kapu elốtt a járdán ülổ lakók látványa sem ritka.

Ezért ezeknek a köztes-összekötổ tereknek a helyzete szintén igen fontos és meghatározó a városrész lakói számára, segítheti vagy ronthatja a városi élet elviselhetốségét.

Ebben a városrészben azért is tulajdonítunk ennek megkülönböztetett figyelmet, mert az itt élổ emberek, családok nagy részének más kikapcsolódási-pihenési-nyaralási lehetôsége nincs! 
Perczel Anna : A Közép-Józsefváros északi területére készülö részletes rendezési terv programja (Detailed plan and program of the Northern part of Central-Josephstadt in Budapest) Tér és Társadalom 6. évf. 1992/3-4. 89-162. $p$.
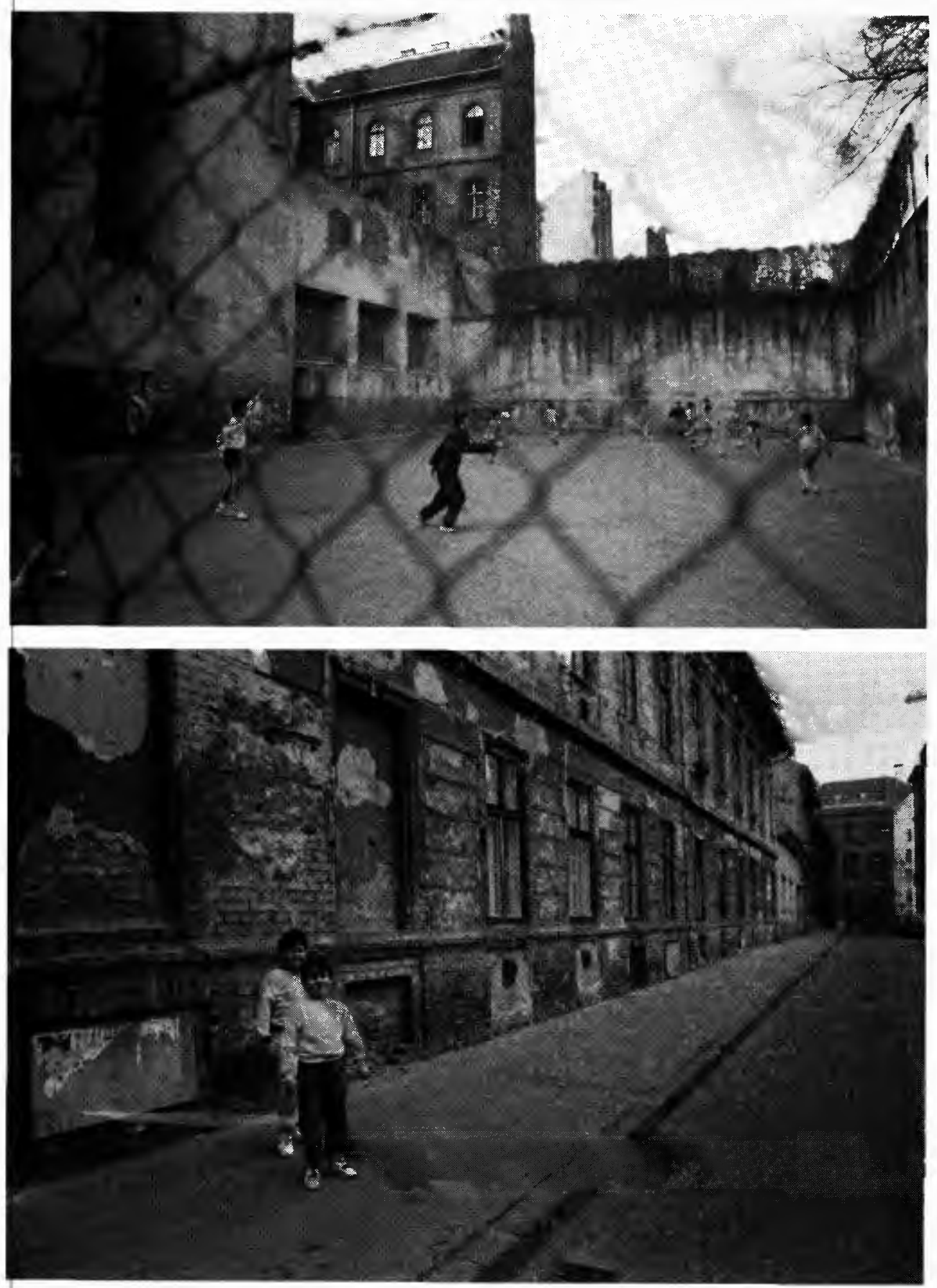

Az iskolaudvarok és az, utcák városi sivataga ... 
Perczel Anna : A Közép-Józsefváros északi területére készülő részletes rendezési terv programja

(Detailed plan and program of the Northern part of Central-Josephstadt in Budapest)

Tér és Társadalom 6. évf. 1992/3-4. 89-162. p.

$\$ 50$ Perczel Anna

TÉT 1992 -3-4
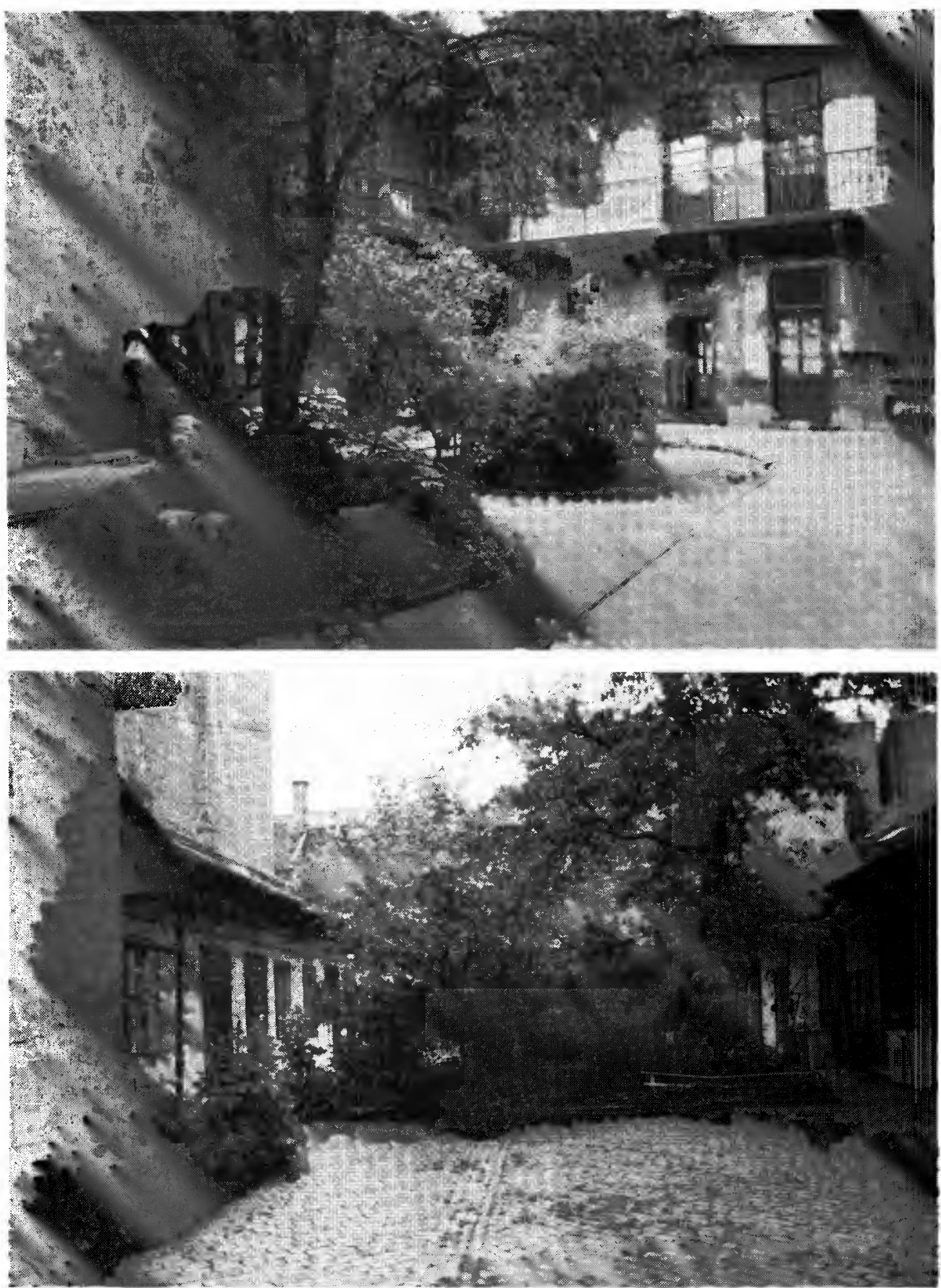

... és a földszintes és I. emeletes lakóházak belsó tereinek oázisai. 
Perczel Anna : A Közép-Józsefváros északi területére készülő részletes rendezési terv programja (Detailed plan and program of the Northern part of Central-Josephstadt in Budapest)

Tér és Társadalom 6. évf. 1992/3-4. 89-162. p.

\section{A kulturális élet kibontakozásának és megerôsödésének meglévô építészeti lehetôségei}

Egy városrész vagy városnegyed belsổ életének felértékelổése, külsố irányból is vonzóvá tétele, szorosan összefügg azzal is, mi mást vagy többet tud nyújtani a többi városnegyedhez képest. Úgy gondoljuk, hogy a kultúra szerepe ilyen szempontból elsódleges és meghatározó, de csak akkor, ha nem csupán kívülról vonzza ide az érdeklôdốket, hanem a városnegyedben \{lổ emberek számára is megfelelốen alakul, változatos és sokrétú.

A részletes vizsgálatok alapján e program kialakítása során ezért különös figyelmet fordítotmunk volt mozik, színház-kabaré, egyesületi székházak dísztermei vagy múhelyépületek, kisüzumek kulturális célra is alkalmas tereinek feltárására, rosszul, vagy bántó módon használt kivételes vagy különleges épületekre.

\section{A munkahelyteremtés épitészeti adottságai}

A lakás és a kultúra nagy kérdéskörei mellett, régi, leértékelôdött városrészek felértékelésének, újjáélesztésének fontos eleme a munkahelyteremtés lehetôségének, ezen belül legváltozato sabb formáinak feltárása.

Itt, a Józsefvárosnak ezen a részén, különlegesen sok olyan építészeti tér, régi bezárt, vagy raktárnak használt mứhely vagy kisüzem található, melyek ilyen célra kiválóan alkalmasak.

A városrészben nagy számban található üres telkek egy részén is mód nyílik azonban olyan kisebb vállalkozások beindítására, melyek a lakókörnyezetet nem terhelve max. 10-25 fố alkalmazásával, elszórtan és változatosan munkalehetôséget adhatnak majd.

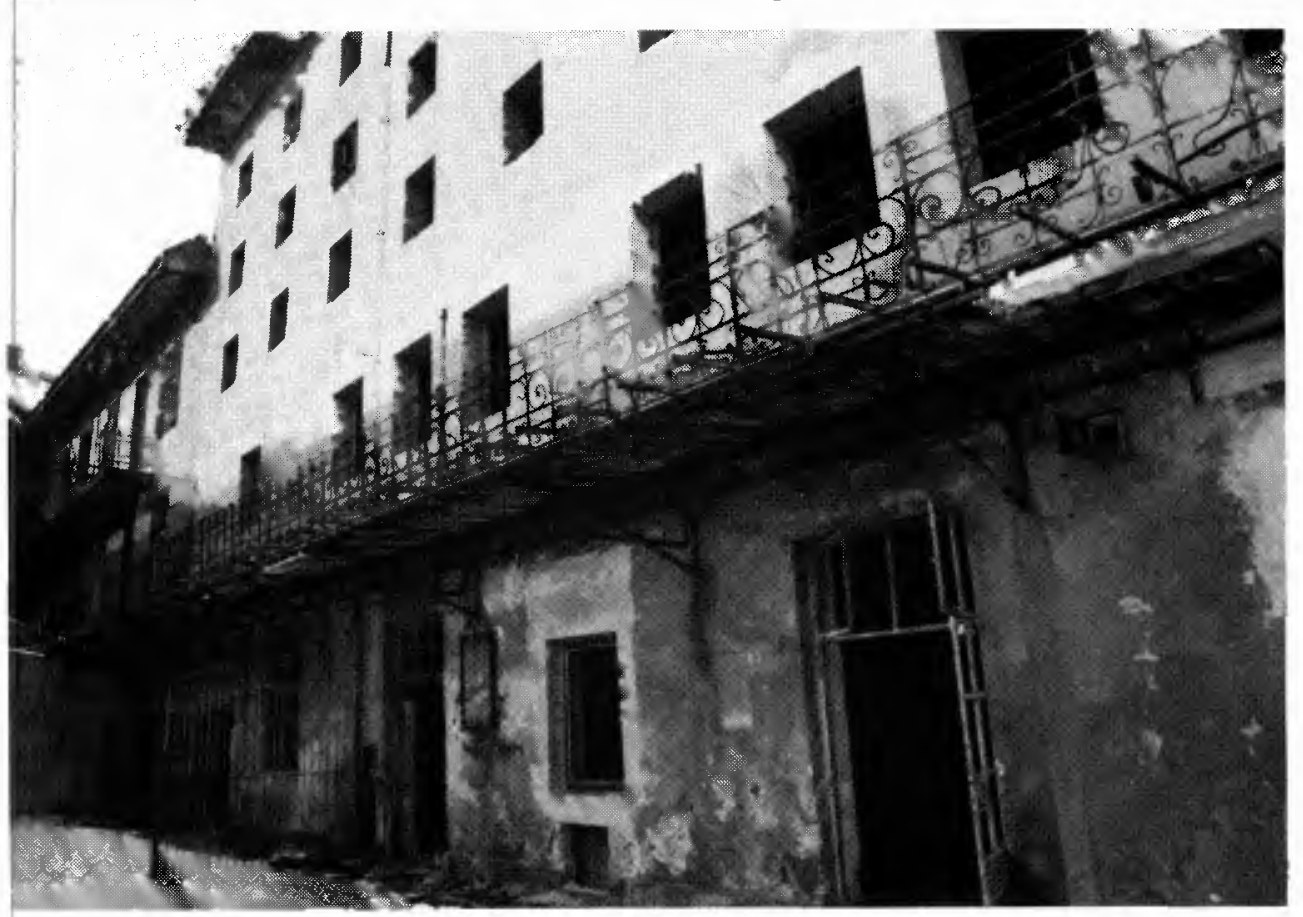

Dankó utca 11 . 
Perczel Anna : A Közép-Józsefváros északi területére készülő részletes rendezési terv programja

(Detailed plan and program of the Northern part of Central-Josephstadt in Budapest)

Tér és Társadalom 6. évf. 1992/3-4. 89-162. p.

\section{A program legfóbb ajánlásai}

1. A városrész történelmi kialakulását, karakterét képviselố sajátos-egyéni varázsát jelentố beépítések, építészeti-természeti-kulturális értékek széles körére vonatkozó védelem (a települési érték fogalmának bevezetése).

2. A városrész adottságaiban rejlô ma még kialakítható környezetet felértékelô lehetôségek hosszútávú biztosítása: játszótér, gyalogos átjárók, sportolási terület, új zöldterület, park, új iskolai terület - udvar, parkolóház, vagy szint alatti parkoló kialakításának lehetốsége.

3. A rehabilitációs folyamattól függetlenül viszonylag kis költséggel is megtehetố környezetet felértékeló lépések azonnali elindítása: fasor, vagy fák ültetése, gyalogos prioritású utcák kialakítása, terek kertészeti rehabilitációja, köztisztaság biztosítása, vizuálisan is környezetet zavaró és leértékelő utcai tárgyak, bódék, reklámok fokozatos visszaszorítása, közvilágítás radikális javítása.

4. A meglévô értékek és a környezetet felértékelổ jövendổ lehetôségek biztosítása mellett a városrész kibontakozását, újjáéledését is segítô szabályozás.

5. A lakossággal történô jobb kapcsolat biztosítása, a nyilvánosság megteremtésére információs iroda kialakítása a helyszínen, a tervek megismertetése, a rehabilitáció fogalmának bevezetése majd elindítása érdekében.

6. Az új építkezések építészeti-városképi színvonalának emelése, de meglévổ régi épületek színvonalas átalakítása érdekében is kerületi építészeti zsüri felállítása, annak véleményeajánlásai alapján történố engedélyezés. Kiemelkedô, hangsúlyos helyzetû́ telkek beépítése esetén tervpályázat kiírása.

7. A jövendố rehabilitáció megkönnyítése érdekében a városrész életében oly fontos szerepet játszó, de hiányzó alapvetô kisebb szociális, kulturális, szolgáltató funkciók biztosítására a legkönnyebben megoldható funkcióváltások megindítása.

8. Részben a funkcióváltások, részben a lakás komfortosítások miatt szükséges ideiglenes vagy végleges új lakás biztosítása érdekében rotációs ház kialakítása vagy építése.

\section{Fơvárosi összefüggéseket érintố javaslatok összegzése}

Baross tér: nagyméretû szint alatti parkoló kiépítése a Keleti pályaudvar mindkét oldalán a Rákóczi út és a belváros tehermentesítése érdekében, a tér kertépítészeti-városképi rendezése, a híd elbontása.

Orczy tér: a fốváros szerkezetében elfoglalt jelentốségének megfelelô funkcionális-közlekedési-városképi átértékelés, nagyméretư szint alatti parkoló kialakítása a Baross utca és a Belváros tehermentesítésére a Józsefvárosi pályaudvar oldalán, a nagyszabású új építési lehetôségek összehangolása a mögöttes területek rehabilitációjával és átalakulási lehetôségeivel, gazdasági-társadalmi elemzés, tervpályázat kiírása. 
Perczel Anna : A Közép-Józsefváros északi területére készülő részletes rendezési terv programja (Detailed plan and program of the Northern part of Central-Josephstadt in Budapest)

Tér és Társadalom 6. évf. 1992/3-4. 89-162. p.

TÉT 1992:3-4

Városrendezés a Józsefvárosban

159

Józsefvárosi p.u.: a konténer pályaudvar megszüntetése illetve kiköltöztetése, elơvárosi pályaudvarként történô használat, Hungária körúti vasúti megállóhely kiépítése, az épületegyüttes mủemléki védelme.

Baross remiz: a Remiz áthelyezése a Salgótarjáni útra, vagy más erre alkalmas területre, a felszabaduló rendkívül értékes terület és épületek hasznosítása: piac, bevásárló központ, zöldterület kialakítására.

Rákóczi út: $\quad$ az átmenó forgalom megszüntetése, a gyalogosforgalom erõsítése, a megszüntetett villamos visszaállítása, járdaszélesítés, fasorültetés, az útvonal teljes hosszában és mindkét oldalán városképi elemzés és terv készítése, a további árkádosítás kérdésének felülvizsgálata.

Fiumei út: $\quad$ forgalmi szerepének tisztázása, körút jellegének erốsítése, a már hosszabb szakaszon létezố zöld sáv és belsố út hiányzó szakaszainak megvalósítása, belsố kerékpárút-korzó kialakítása.

Baross utca: a közlekedési zsúfoltság oldása az átmenố forgalom megszüntetésével, a fasor teljes rehabilitációja, portálok védelme, a közvilágítás világvároshoz igazodó kialakítása.

Rekonstrukciós körút terve: ÁRT szintũ felülvizsgálat, az érvényben lévô 1988-i RRT és szabályozás érvényességének megszüntetése, olyan terv kidolgozása, mely sem városszerkezet rombolásával, sem épületek tömegének bontásával nem jár.

\section{Összefoglaló gondolatok}

A Közép-Józsefváros északi része a leértékelődés, szlömösödés és társadalmi erózió olyan stádiumába jutott, ahol már egy-egy telek, egy-egy utcaszakasz vagy tömb szigetszerú átalakulása önmagában döntố változást nem eredményezhet.

Ezért e városrendezési program kialakítása során az egész városrészre vagy annak egy-egy nagyobb egységére is kisugárzó rehabilitációs folyamatban gondolkodtunk.

$\mathrm{Az}$ átalakulás és a felértékelốdés elindítása a leépülés ilyen fokán tisztán vállalkozói alapon vagy tisztán önkormányzati erốbốl elképzelhetetlen, nem múködik. Elfogadhatatlan az az út is, amikor a rehabilitáció a területen élổ emberekkel nem számolva, azok elköltözésére épít.

De azt az utat sem tartjuk járhatónak, melynek során a városrész sajátos jellegét, karakterét jelentố beépítések - építészeti értékek vagy zöldfelületek eltúnése árán - történne a változás. 
Perczel Anna : A Közép-Józsefváros északi területére készülő részletes rendezési terv programja

(Detailed plan and program of the Northern part of Central-Josephstadt in Budapest)

Tér és Társadalom 6. évf. 1992/3-4. 89-162. p.

160 Perczel Anna

TÉT $1992 \cdot 3-4$

A leértékelôdött történelmi városrészek esetében a nyugateurópai tapasztalatok is mind a rehabilitáció összetett (kormány-önkormányzat- lakossági- vállalkozói) finanszírozását és érzékeny társadalmi és építészeti megközelítését igazolják.

Mindezt figyelembevéve e rendezési terv készítése során, - már a jövendố és elkerülhetetlen rehabilitációra is gondolva, szociológusokkal és közgazdászokkal együtt alakítottuk ki építészeti-, városrendezési javaslatainkat, a városrész karakterének és helyzetének megfelelố összetettségre és érzékeny megközelítésre törekedve és felhasználva a szociális ajánlásokat és a gazdálkodási program által vázolt kitörési lehetôségeket is.

A rehabilitációt, a kimozdulást a városrészre jellemzổ történeti-építészeti-természeti kulturális értékekre építve, a beépítés léptékéhez és a folytatandó tradíciókhoz igazodóan, a városrész lakóinak részvételével, többségük maradására számítva képzeltük el, ugyanakkor társadalmikörnyezeti-építészeti megújulásra is gondolva, hiszen ez így együtt a rehabilitáció lényege.

Erre az ún. ,óvatos" rehabilitációra esélyt ad:

- a városrészben található, bontás nélkül is beépíthetô üres telkek-telephelyek igen nagy száma (a telkek $15 \%$ ), de az építészeti-városképi értéket nem képviselô, rossz állapotú, környezetet is zavaró, így bontható épületek viszonylag magas aránya is. (5-9\%)

- mindez egyformán ad lehetốséget vállalkozás jellegư építkezéseknek, nagyobb lakásépítési akcióknak, de foghíjszerû́ beépítéseknek is anélkül, hogy a meglévô értékes, történelmi folyamatosságot is biztosító épületeket, vagy akár lakóközösségeket komolyabban meg kellene bolygatni,

- az üres vagy üressé váló telkek magas aránya nemcsak új építkezéseknek, de új parkok, játszóterek, iskolaudvarok vagy iskolai kertek, sportterületek, tehát a környezetet komolyan felértékelố-javító megoldások számára is lehetôséget ad,

- a megújulásban szerepet játszhat a városrész igen elổnyös központi elhelyezkedése a fốváros szerkezetében, a városrészhez közvetlenül kapcsolódó pályaudvarok, nagykiterjedésû zöldterületek, de a belsô parkok-közterek szokatlan nagy száma is,

- a városrész sajátos fejlổdésébốl következôen megmaradt, ezért egyéni karakterét jelentô, egyben elsố beépülési korszakát is képviselố földszintes és I. emeletes falusias, illetve kisvárosias jellegü lakóépulletek és beépitések megốrzésével és védelmével lehetôség nyîlik a sũrũn beépített pesti oldal bérházai között a személyesebb - kisvárosiasabb életvitelre is, vagy közủlük egy-egy épület funkcióváltásával a városrészben annyira hiányzó kisebb szociális - kulturális - szolgáltató funkciók kialakítására, akár az itt hajdanán hagyományosnak számító vendéglátás ill. vendéglốk kialakítására - visszaállítására,

- e városrész másik sajátossága, védendổ jellegzetessége a lakóházak udvarán itt oly gyakran elôforduló mühelyépület, hajdani kis gyár is ragyogó lehetôség a szelíd de hatékony változásra, hiszen alkalmas új munkahelyek kialakítására vagy iparosok, mũvészek befogadására..

A rehabilitáció során ugyanakkor itt olyan rendkivül súlyos problémákkal kell szembenézni, mint:

- a komfortnélküli és rossz állapotú sötét-vizes lakások tömeges jelenléte (45\%) és a lakóépületek többségének erốteljesen leromlott állapota,

- a belsổ utcák elsorvadt élete: sem üzlet, sem szolgáltatás, sem vendéglátás, csak kosz, elhanyagoltság, rossz közvilágítás, újabban pince-borozó, peep show, bingo terem, 
Perczel Anna : A Közép-Józsefváros északi területére készülő részletes rendezési terv programja (Detailed plan and program of the Northern part of Central-Josephstadt in Budapest)

Tér és Társadalom 6. évf. 1992/3-4. 89-162. p.

TÉT 1992-3-4

Városrendezés a Józsefuárosban

161

- az indokolatlanul elbontott régi házak helyére települt környezetet terhelô, zavaró és leértékelô, talajt szennyezõ telephelyek, gépkocsitảrolók rendkívül nagy száma,

- a prostituált negyed egyre korlátlanabb területhódítása,

- a városrész lakóinak életéhez közvetlenül kötốdố szociális-kulturális-szolgáltató funkciók hiányos jelenléte, olykor teljes hiánya, (több mint 10000 diák mellett),

— az általános iskolák, óvodák komoly túlterheltsége ( 20\%) és teremhiánya mellett a rossz körzeti elosztás és sok esetben hiányzó udvar, park, tornaterem, közösségi terem,

- kevés és egészségtelen, szennyezett levegôjủ játszótér,

- a sportolási lehetốség teljes hiánya,

- e szociális területen igencsak segítségre szoruló és egyben elöregedett városrészben a szociális ellátás hiányos jelenléte és az erre szolgáló építészeti terek alkalmatlansága.

Mindezek következtében

a perifériára szorult, hátrányos helyzetư emberek családok (szegények, munkanélkuiliek, cigányok) egyre gyorsabban növekvô jelenléte, az itt élók elöregedése, a jobbmódú, tanultabb polgári családok elköltözése, - a gettósodási folyamat felgyorsulása.

Az itt felsorolt igencsak súlyos belsó problémákat további külsó, elsôsorban a fóváros hatáskörébe tartozó, a kibontakozást nehezitố gondok terhelik, melyek közül a legjelentôsebbek:

- a városrészt övezố fốútvonalak elfogadhatatlan mértékü és minôségư forgalma, az ezzel együttjáró levegôszennyezettség, zaj, rezgés és porterhelés,

- a megoldatlan parkolási kérdések a fổútvonalak környezetében, de belsổ utcákban is,

- Orczy tér és környékének városszerkezeti, közlekedési, városképi, funkcionális megoldatlansága,

- a Baross Remiz kibontakozást gátló, zavaró jelenléte,

- a Gázmũvek területének környezetet leértékelô használata,

- a Józsefvárosi-pályaudvar leértékelt kezelése, fejlesztési lehetóségeinek kihasználatlansága.

A modern nagyvárosok itt láthatóan egy helyre koncentrálódó összes hagyományos és új, de mindenképpen , ,kemény" problémái mellett a Józsefvárosnak ez a része építészeti értékekben, tradícióban meglepõen gazdag, rendkívül változatos és egyben hihetetlenül ellentmondásos világot képvisel.

A változatosság és ellentmondásosság éppúgy megnyilvánul a városrész szerkezetében, beépítettségében, mint lakóépületeinek vagy belsố udvarainak, kertjeinek sokféleségében, de társadalmi rétegzôdésében is.

Feltûnố az az ellentmondás, az a kontraszt is, amely a városrészben található igen nagyszámú közintézmény iskola magas színvonala, jelentôsége és a városrész pusztulást sugalló, leépült mai helyzete vagy külsổ megítélése, presztizse között fennáll.

Mindez nagyrészt e városrész szaggatott és ellentmondásos fejlốdéséból, s e meg-megújuló, majd mindig elakadó fejlôdésnek sokszor ellentmondó városrendezési szabályozásból-, de belváros és külváros közötti köztes helyzetébôl is fakad.

Ma egyszerre van itt jelen a polgári világ a munkás bérkaszárnyák és a külváros világával, a nagyváros a kisvárossal, olykor a falu világával is, keveredve.

Ez a József körút mentén még Belvárost képviselổ városrész a Dobozi utca — Orczy tér kör- 
Perczel Anna : A Közép-Józsefváros északi területére készülő részletes rendezési terv programja

(Detailed plan and program of the Northern part of Central-Josephstadt in Budapest)

Tér és Társadalom 6. évf. 1992/3-4. 89-162. p.

162 Perczel Anna

TÉT $1992 \cdot 3-4$

nyékén már a körút polgári világától élesen különbözổ külvárost, munkások és hajléktalanok világát idézi.

A nagy kontraszt, ellentét nemcsak a városrész két pólusa között, de a városrészen belül egyegy utcában, tömbön belül is jellemzó.

Igen gyakori kép a belsố utcákban és terek körül az V-VI. emeletes szecessziós bérházak tövében álló múltszázadból ittmaradt földszintes lakóház, majd a III. emeletes eklektikus bérház mellett húzódó telephely, üres telek, üzemi épület és az ,,elókelổ” múltra visszatekintố polgári bérház mellett sorakozó ,,munkásbérkaszárnya” is.

A lakóépületek, bérházak kapuján belépve a különleges szépségũ és hangulatú belsổ terek - udvarok olykor gazdag növényzetư elvarázsolt kertek mellett ott találhatók a kétségbeejtôen sivár, sötét és dohos udvarok is.

A program javaslatait ennek a változatos és ellentmondásos helyzetnek megfelelve fogalmaztuk meg, egyrészt a történelem során eltérỏen alakult városszerkezeti egységek és a rehabilitáció szempontjaiból más- és más stratégiát igénylổ területek, másrészt az egymástól különbözổ tömbök utcák, épületek esetében.

Azonban minden összetettség és különbözóség ellenére az egész városrészre vonatkozóan egyformán alapvetônek és fontosnak tekintettü:

- a városrészt alakító, egymás mellett fellelhetổ három nagy történelmi stílus-korszak jellegzetes, vagy építészetileg kiemelkedô épületeinek, beépítéseinek számbavételét - megôrzését - védelmét, a történelmi folyamatosság biztosítását,

- a parkok és fasorok növényzete mellett, a városrészre oly jellemzố belsổ kertek megổrzését, befuttatott túzfalak, értékes növényzet védelmét, értékként történổ számontartását,

- az elviselhetố városi élet érdekében: a forgalomcsillapított vagy gyalogos-elsốbbségư utcák hálózatának kialakítását, a forgalmi rend javítását, a zöldterületek minden lehetséges formában történô növelését,

- az iskolák, óvodák közvetlen szomszédságában lévổ üres vagy felszabadítható telkek iskolabỏvítésére, iskolaudvar vagy kert kialakítására történô felhasználását, illetve tartalékolását,

- a környezetet elổreláthatóan legkevésbé terhelổ parkolási lehetőségek területi biztosítását,

- az értékének és jellegének nem megfelelôen, méltatlanul, rosszul vagy zavaróan használt különleges épületek, nagyobb belsổ terek funkcióváltását,

- sötét lakóudvarok földszinti lakásainak átalakulását, lakásként történô használatának megszüntetését.

Ezen túl különös jelentốséget tulajdonítottunk a városrész teljes területén:

- a közösségi élet színtereinek: tereknek, parkoknak kivételes utcáknak,

- a félközösségi tereknek: tömbbelsổ, udvar, kert és telek használatának,

- a kulturális élet kibontakozását, megerôsítését segítố, rosszul használt építészeti terek feltárásának,

- a munkahelyteremtésre felhasználható épületek megổrzésének,

— a jelenleg elsôsorban üzlehelyiségekben történổ öregekkel való foglalkozás megfelelốbb, emberibb lehetôségek feltárásának, elsősorban erre alkalmas földszintes-kertes épületek funkcióváltására gondolva. 